UNIVERSIDADE FEDERAL DE SÃO CARLOS

CENTRO DE CIÊNCIAS E TECNOLOGIAS PARA A SUSTENTABILIDADE PROGRAMA DE PÓS-GRADUAÇÃO EM ENGENHARIA DE PRODUÇÃO - PPGEPS

PAULA HORTA LEMOS

ANÁLISE DE DECISÃO MULTICRITÉRIO PARA AVALIAÇÃO DE ALTERNATIVAS DE RECOLHIMENTO DE PALHIÇO DE CANA-DE-AÇÚCAR PARA A COGERAÇÃO DE ENERGIA 
UNIVERSIDADE FEDERAL DE SÃO CARLOS

CENTRO DE CIÊNCIAS E TECNOLOGIAS PARA A SUSTENTABILIDADE PROGRAMA DE PÓS-GRADUAÇÃO EM ENGENHARIA DE PRODUÇÃO - PPGEPS

PAULA HORTA LEMOS

\section{ANÁLISE DE DECISÃO MULTICRITÉRIO PARA AVALIAÇÃO DE ALTERNATIVAS DE RECOLHIMENTO DE PALHIÇO DE CANA-DE-AÇÚCAR PARA A COGERAÇÃO DE ENERGIA}

Dissertação de mestrado apresentada ao Programa de Pós-Graduação em Engenharia de Produção da Universidade Federal de São Carlos - Campus Sorocaba, como parte dos requisitos para a obtenção do título de Mestre em Engenharia de Produção.

Orientador: Prof. Dr. José Geraldo Vidal Vieira Co-orientador: Prof. Dr. João Eduardo Azevedo Ramos da Silva

Financiamento: Coordenação de Aperfeiçoamento de Pessoal de Nível Superior - CAPES.

Sorocaba 


\section{Horta Lemos, Paula}

Análise de decisão multicritério para avaliação de alternativas de recolhimento de palhiço de cana-de-açúcar para a cogeração de energia / Paula Horta Lemos. -- 2018.

$120 \mathrm{f} .: 30 \mathrm{~cm}$.

Dissertação (mestrado)-Universidade Federal de São Carlos, campus Sorocaba, Sorocaba

Orientador: Dr. José Geraldo Vidal Vieira, Dr. João Eduardo Azevedo Ramos da Silva

Banca examinadora: Dr. Carlos Eduardo Osório Xavier, Dra. Caroline Maria de Miranda Mota

Bibliografia

1. Recolhimento de palhiço. 2. Cogeração de energia. 3. Análise de decisão multicritério. I. Orientador. II. Universidade Federal de São Carlos. III. Título.

Ficha catalográfica elaborada pelo Programa de Geração Automática da Secretaria Geral de Informática (SIn).

DADOS FORNECIDOS PELO(A) AUTOR(A)

Bibliotecário(a) Responsável: Maria Aparecida de Lourdes Mariano - CRB/8 6979 


\section{UNIVERSIDADE FEDERAL DE SÃO CARLOS}

Centro de Ciências em Gestão e Tecnologia Programa de Pós-Graduação em Engenharia de Produção

\section{Folha de Aprovação}

Assinaturas dos membros da comissão examinadora que avaliou e aprovou a Defesa de Dissertação de Mestrado da candidata Paula Horta Lemos, realizada em 27/02/2018:

\section{Vidal}

Prof. Dr. José Geraldo Vidal Vieira

UFSCar

Profa. Dra. Caroline Maria de Miranda Mota

UFPE

Arlos Xavier

Prof. Dr. Carlos Eduardo Osório Xavier

UFSCar

Certifico que a defesa realizou-se com a participaçāo à distância do(s) membro(s) Caroline Maria de Miranda Mota e, depois das arguiçōes e deliberaçōes realizadas, o(s) participante(s) à distância está(ao) de acordo com o conteúdo do parecer da banca examinadora redigido neste relatório de defesa. 
"Consulte não a seus medos mas a suas esperanças $e$ sonhos. Pense não sobre suas frustrações, mas sobre seu potencial não usado. Preocupe-se não com o que você tentou e falhou, mas com aquilo que ainda é possível a vocêfazer."

(Papa João XXIII) 


\section{AGRADECIMENTOS}

Agradeço a DEUS por ter me direcionado à Pós Graduação em Engenharia de Produção da UFSCar e à conclusão de cada uma das fases do Mestrado.

À minha família, pelo apoio que sempre me proporcionaram. À minha mãe, Maria Angélica, por estar sempre torcendo por mim e disposta a ouvir minhas alegrias, angústias e entusiasmar-se sempre comigo. Ao meu pai, Joaquim, pela formação que me proporcionou e por estar sempre orgulhoso das minhas conquistas. Minha irmã, Carla, por estar sempre ao meu lado.

Ao meu marido, Lucas, pela paciência com minhas inquietações, por sempre ouvir minhas dúvidas, por não me deixar desanimar e pela força durante a coleta de dados nas usinas.

À Universidade Federal de São Carlos (UFSCar) pela estrutura ofertada ao longo da minha vida acadêmica desde a graduação. À CAPES pela concessão da bolsa de estudos.

Ao meu orientador, Professor José Geraldo Vidal Vieira, pela orientação desde a iniciação cinetífica até o mestrado. Pelas oportunidades oferecidas, confiança, compromisso e abertura ao diálogo.

Ao meu coorientador, Professor João Eduardo Azevedo Ramos da Silva, pela partilha de conhecimentos, atenção e conselhos ofertados ao longo da pesquisa.

À banca examinadora, Carlos Xavier e Caroline Mota, pela disposição em participar do trabalho e contribuições oferecidas.

Às usinas visitadas, por abrir as portas para a realização de entrevistas e coleta de dados.

À Érica pela competência e disposição em ajudar sempre que possível. Aos colegas do mestrado, em especial Nayara, Camila e amigos colombianos pelos momentos de convivência, amizade e descontração. 


\section{RESUMO}

LEMOS, Paula H. Análise de decisão multicritério para avaliação das alternativas de recolhimento de palhiço de cana-de-açúcar para a cogeração de energia. 2018. xxxx. Dissertação (Mestrado em Engenharia de Produção) - Universidade Federal de São Carlos, Sorocaba.

O setor sucroalcooleiro figura entre as mais tradicionais e antigas indústrias de processamento da biomassa no Brasil. A biomassa da cana é dividida em duas categorias: o bagaço de cana, disponível na indústria após a extração do caldo e já utilizado como insumo energético; e o palhiço, objeto de estudo desta pesquisa, que fica disponível no campo após a colheita da cana. Com a permanência do palhiço de cana-de-açúcar no solo após a proibição da pré-queima na colheita manual, novos problemas surgiram, como a infestação por pragas e o retardamento da brotação da cana. Uma alternativa para o excesso de palhiço no solo é o recolhimento dessa biomassa no campo para a cogeração de energia. Porém, o elevado custo associado ao recolhimento de palhiço constitui a explicação mais plausível para a pequena geração de excedentes de energia pelo setor. As alternativas de recolhimento mais em uso são a colheita integral, colheita parcial e o enfardamento. Na alternativa de colheita integral, a cana como um todo, colmo e palhiço, é transportada para a usina, onde, em uma estação de limpeza se realiza a separação do palhiço. Por outro lado, na colheita parcial, parte do palhiço fica no solo e a outra parte do palhiço é transportada junto com a cana para a indústria onde são separados na estação de limpeza. No enfardamento, após a colheita mecanizada convencional, o palhiço é deixado no campo para uma secagem natural. Após esse período o palhiço é enleirado, enfardado em campo e transportado para a usina. Muitos critérios devem ser considerados para a escolha da melhor alternativa no processo de recolhimento do palhiço como custos com transporte, umidade e densidade do palhiço, a qualidade do palhiço, a eficiência de separação cana/palhiço, custos de investimentos e operacionais do recolhimento, preço da energia, receita com a cogeração, entre outros, existindo assim um trade off em relação a esses critérios e as alternativas de recolhimento de palhiço. Assim, foi elaborado um modelo genérico de análise de decisão multicritério a partir da ferramenta SMART (Simple Multi-Attribute Ranking Technique) para auxiliar empresas do setor sucroalcooleiro sobre a alternativa de recolhimento de palhiço para a cogeração de energia. O modelo foi construído a partir da literatura e validado por gestores de usinas sucroalcooleiras. Como soluções provisórias, as opções de colheita integral e enfardamento foram as alternativas sugeridas. Porém, a abordagem proposta permitiu analisar com robustez a decisão mais adequada por meio de análises de sensibilidade como variação na ponderação dos pesos dos critérios supra citados e a análise de Monte Carlo para variação do preço da energia. Após a realização da análise de Monte Carlo, os resultados mostraram que em $41 \%$ dos preços de energia simulados a solução recomendada é a de colheita integral. A solução sugerida pela metodologia não é a solução ótima em custo visível, mas por outro lado, ela fornece o melhor desempenho geral atendendo os critérios da estrutura hierárquica de objetivos. Além de um custo aceitável e um alto valor esperado da receita, esta solução satisfaz outras necessidades do modelo, isto é uma importante contribuição, especialmente nos casos onde muitos objetivos conflitantes estão presentes.

Palavras-chave: Cana-de-açúcar; Recolhimento de palhiço; Cogeração de energia; Análise de decisão multicritério. 


\begin{abstract}
The sugar and alcohol industry is among the most traditional and old biomass processing industries in Brazil. Cane biomass is divided into two categories: sugarcane bagasse, available in the industry after the extraction of the juice and already used as an energy input; and the trash, object of study of this research, that is available in the field after the cane harvest. With the permanence of trash in the soil after the prohibition of pre-burning in manual harvesting, new problems have arisen, such as pest infestation and cane sprout retardation. An alternative to excess trash in the field, can be the collection of this biomass in the field for cogeneration of energy. However, the high cost associated with the collection of trash is the most plausible explanation for the small generation of surplus energy by the sector. The most widely used picking alternatives are the whole harvest, partial harvest and the baling. In the alternative of integral harvest, the cane and the trash are transported to the plant, where in a cleaning station the separation of the trash is carried out. On the other hand, in the partial harvest part of the trash is in the soil and the other part of the trash is transported along with the cane for industry and then they are separated in the cleaning station. In the baling, after the conventional mechanized harvest, the trash is left in the field for natural drying, after which the trash is enclose, packaged in the field and transported to the plant. Many criteria should be taken into account when choosing the best alternative in the process of obtaining trash, such as transportation costs, trash wetness, trash quality, separation efficiency of the cane and trash, investment and operating costs with collection, revenue from cogeneration, among others, thus there is a trade off in relation to these criteria and the alternatives for collecting trash. Thus, a generic multicriteria decision analysis model was elaborated from the SMART tool (Simple Multi-Attribute Ranking Technique) to assist companies in the sugar and alcohol industry on the alternative of collecting trash for the cogeneration of energy. The model was applied in mills of the sector. As a provisional result, the integral harvest and baling option were the suggested alternatives. However, the proposed approach allowed us to robustly analyze the most appropriate decision by means of sensitivity analyzes such as variation in the weights os the cited criteria and Monte Carlo analysis for energy price variation. After a Monte Carlo analysis, the results showed that at $41 \%$ of the simulated energy prices the recommended solution is a harvest integral. The solution suggested by the methodology is not the optimal solution in visible cost. On the other hand, it provides the best overall performance by meeting the criteria of the hierarchical structure of objectives. In addition to an acceptable cost and a high expected value of revenue, this solution satisfies other needs of the model, this is an important contribution, especially in cases where many conflicting objectives appear.
\end{abstract}

Keywords: Sugarcane; Trash collection; Energy cogeneration. Multicriteria decision analysis. 


\section{LISTA DE FIGURAS}

FIGURA 1: ESTRUTURA DA PESQUISA

FIGURA 2: MATRIZ ELÉTRICA BRASILEIRA NOS ANOS DE 2015 E 2016. FONTE: EPE (2016)...........................................24

FiguRA 3: PRoJeÇõES DE GERAÇÃo DE ENERGIA A PARTIR DA BIOMASSA DE CANA-DE-AÇÚCAR. FONTE: UNICA (2010)....25

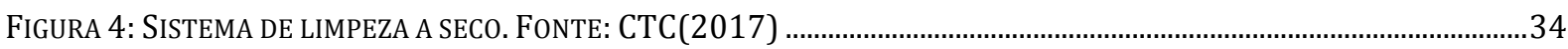

FIGURA 5: EFICIÊNCIA DE SEPARAÇÃO CANA/PALHIÇO NO SISTEMA DE LIMPEZA A SECO. FONTE: CTC(2017).......................35

FIGURA 6: ETAPAS DO ENFARDAMENTO. FONTE: SELEGATO (2012) …...........................................................................36

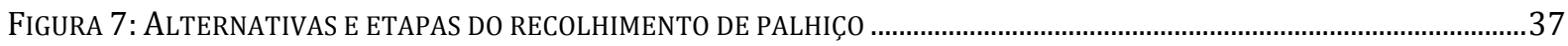

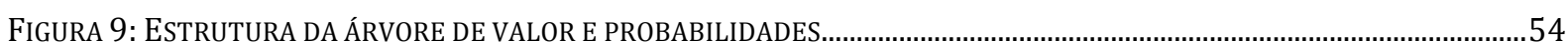

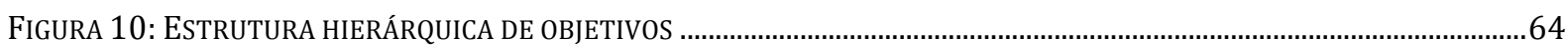

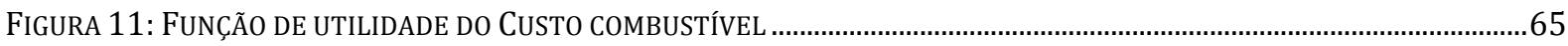

FIGURA 12: FUNÇÃO UTILIDADE DO CUSTO MÃO-DE-OBRA …...........................................................................................66

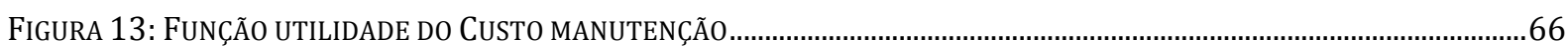

FIGURA 14: FUNÇÃO UTILIDADE DOS OUTROS CUSTOS OPERACIONAIS ................................................................................67

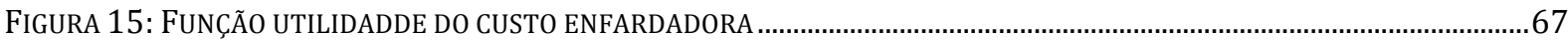

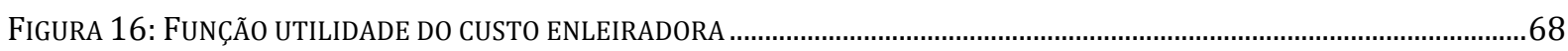

FIGURA 17: FUNÇÃO UTILIDADE DO CUSTO TRANSPORTE DE FARDOS .................................................................................68

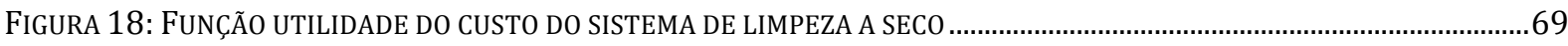

FIGURA 19: FUNÇÃO UTILIDADE DOS OUTROS CUSTOS DE INVESTIMENTO _..........................................................................69

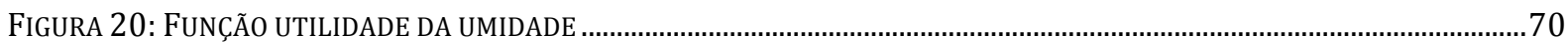

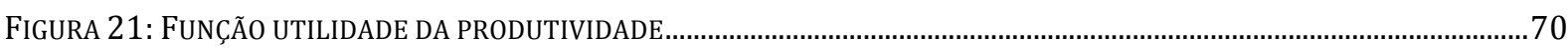

FIGURA 22: FUNÇÃO UTILIDADE DO TEOR DE IMPUREZAS …..........................................................................................

FIGURA 23: FUNÇÃO UTILIDADE DA EFICIÊNCIA DE SEPARAÇÃO CANA/PALHIÇO ...................................................................71

FIGURA 24: FUNÇÃO UTILIDADE DO VALOR ESPERADO DA RECEITA..................................................................................

FIGURA 25: ÁRVORE BASEADA EM VALOR E PROBABILIDADES .............................................................................................

FIGURA 26: ESTRUTURA HIERÁRQUICA DE OBJETIVOS COM PESOS INTEGRADOS …..............................................................8

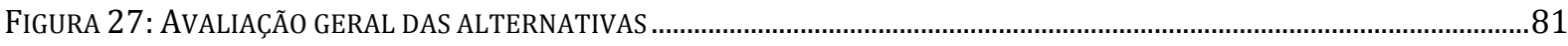

FIGURA 28: AVALIAÇÃO CUSTOS X VARIÁVEIS AGROINDUSTRIAIS ......................................................................................8

FIGURA 29: AVALIAÇÃO VALOR ESPERADO DA RECEITA X CUSTOS........................................................................................

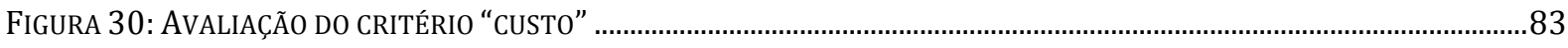

FIGURA 31: AVALIAÇÃO DO CRITÉRIO “CUSTO OPERACIONAL” ...............................................................................................83

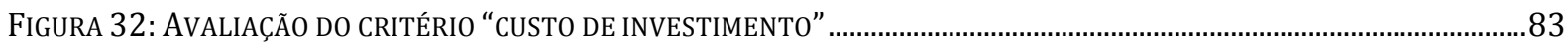

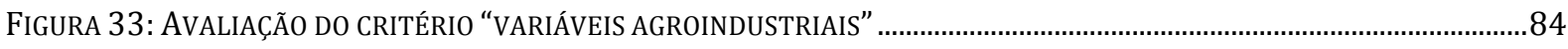

FIGURA 34: AVALIAÇÃO DO CRITÉRIO “VARIÁVEIS AGRONÔMICAS” ......................................................................................8

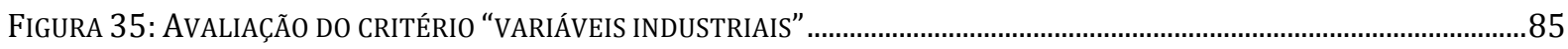

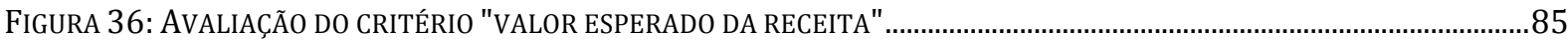

FIGURA 37: ANÂLISE DE SENSIBILIDADE PARA VARIAÇ̃̃o DOS PESOS DO CRITÉRIO "VARIÁVEIS AGROINDUSTRIAIS"...............87 
FiguRA 38: ANÁLISE DE SENSIBILIDADE PARA VARIAÇÃO DOS PESOS DO CRITÉRIO "CUSTOS"

FIGURA 39: ANÁLISE DE SENSIBILIDADE PARA VARIAÇÃO DOS PESOS DO CRITÉRIO "VALOR ESPERADO DA RECEITA" 88

FIGURA 40: DESEMPENHO DAS ALTERNATIVAS POR MEIO DOS PESOS ROC 90

FigURA 41: FREQUÊNCIA DAS ALTERNATIVAS DE RECOLHIMENTO SUGERIDAS PELA ANÁLISE DE MONTE CARLO .93

FIGURA 42: FUNÇÃO UTILIDADE EXEMPLO PARA O TEOR DE IMPUREZAS DO PALHIÇO 109 


\section{LISTA DE QUADROS}

QUADRO 1: COMPARAÇÃO ENTRE AS CARACTERÍSTICAS DO BAGAÇO E PALHIÇO .......................................................................28

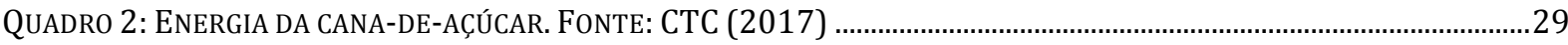

QUADRO 3: DIFERENÇAS DOS SISTEMAS DE RECOLHIMENTO INTEGRAL, PARCIAL E ENFARDAMENTO ......................................39

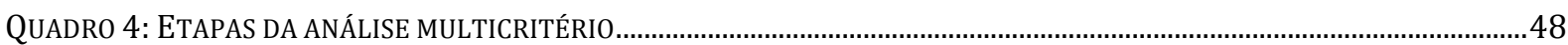

QUADRO 5: PLD MÉDIO (R\$) NO PERÍODO DE JUL./2016 A JUN./2017 NAS REGIÕES SE E CO. FONTE: CCEE....................52

QUADRo 6: PARÂMETROS REFERENTES AOS DADOS DO PLD DE 2014 A 2017 .............................................................52

QUADRO 7: CARACTERÍSTICAS REFERENTE AOS DADOS DO PLD DE 2014 A 2017 ......................................................53

QUADRo 8: ATRIBUIÇÃO DE PESOS COM O MÉTOdO SMART. FONTE: GoOdWIN E WRIGHT, 2005 ......................................55

QUADRO 9: PESOS ROC DE ACORDO COM O NÚMERO DE ATRIBUTOS. FONTE: EDWARDS E BARRON (1994) .........................56

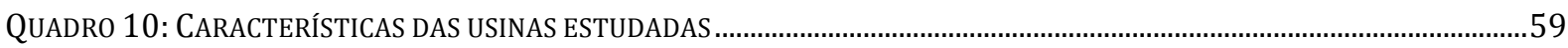

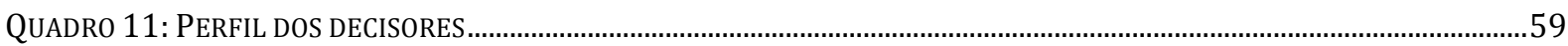

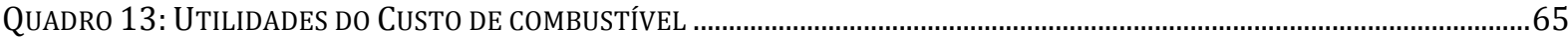

QUADRO 14: UTILIDADES DO CUSTO MÃO-DE-OBRA.................................................................................................6

QUADRO 15: UTILIDADE DO CUSTO DE MANUTENÇÃO.................................................................................................6

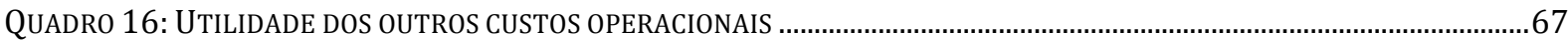

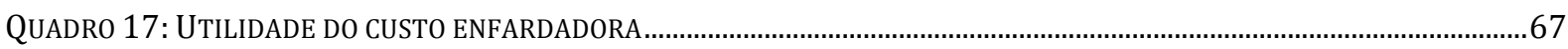

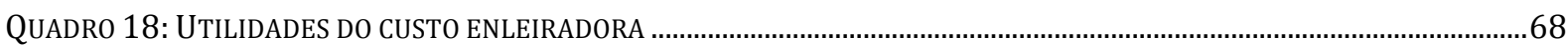

QUADRO 19: UTILIDADES DO CUSTO TRANSPORTE DE FARDOS..................................................................................................68

QUADRO 20: UTILIDADES DO CUSTO DO SISTEMA DE LIMPEZA .......................................................................................69

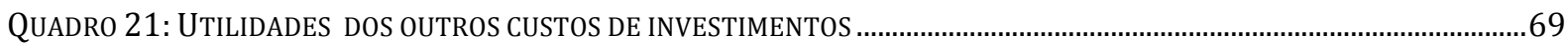

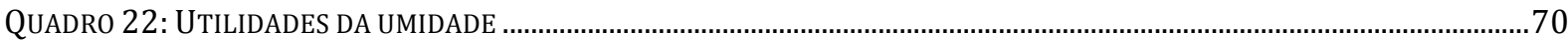

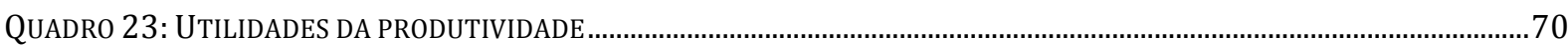

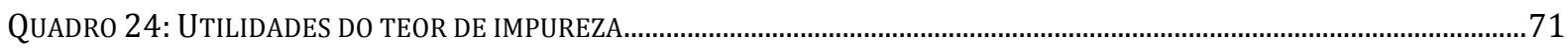

QUADRO 25: UTILIDADES DA EFICIÊNCIA DE SEPARAÇÃO CANA/PALHIÇO............................................................................71

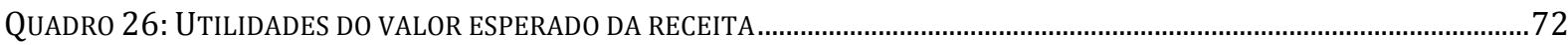

QUADRO 27: CÁLCULO DO VALOR ESPERADO DA RECEITA PARA A ALTERNATIVA DE ENFARDAMENTO ....................................73

QUADRO 28: CÁLCULO DO VALOR ESPERADO DA RECEITA PARA A ALTERNATIVA DE COLHEITA INTEGRAL..............................73

QUADRO 29: CÁLCULO DO VALOR ESPERADO DA RECEITA PARA A ALTERNATIVA DE COLHEITA PARCIAL .................................74

QUADRO 30: VALOR ESPERADO DA RECEITA DA VENDA DE ENERGIA.....................................................................................76

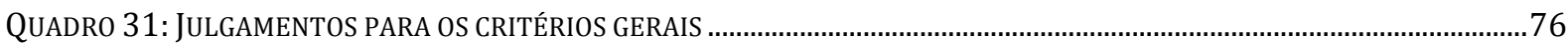

QUADRO 32: JULGAMENTOS PARA OS CRITÉRIOS DE CUSTO ….......................................................................................

QUADRO 33: JULGAMENTOS PARA OS CRITÉRIOS DE VARIÁVEIS AGROINDUSTRIAIS................................................................77

QUADRO 34: JULGAMENTO PARA OS CRITÉRIOS DE CUSTOS OPERACIONAIS ...........................................................................77

QUADRO 35: JULGAMENTO PARA OS CRITÉRIOS DE CUSTOS DE INVESTIMENTOS....................................................................78

QUADRO 36: JULGAMENTOS PARA OS CRITÉRIOS DE VARIÁVEIS AGRONÔMICAS ......................................................................78

QUADRO 37: JULGAMENTOS PARA OS CRITÉRIOS DE VARIÁVEIS INDUSTRIAIS ..........................................................................79

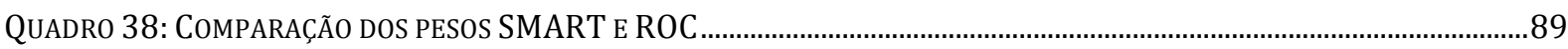


QUADRO 39: LIMITES INFERIOR E SUPERIOR, NÚMERO DE OCORRÊNCIAS E FREQUÊNCIA DOS DADOS DE PLD 91

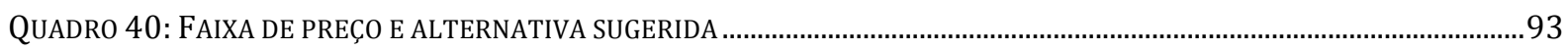

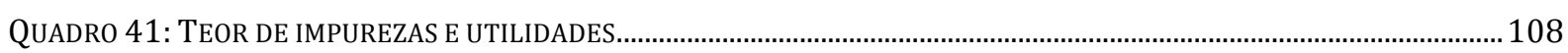

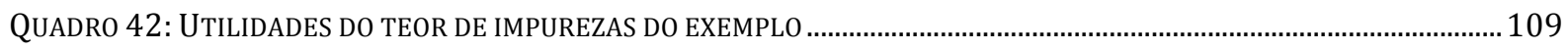

QUADRO 43: ATRIBUIÇÃO DE PESOS COM SWING WEIGHTING …...................................................................................110

QUADRO 44: ESCALA FUNDAMENTAL DE SAATY. FONTE: SAATY (1980) ...................................................................... 111

QUADRO 45: RECEITAS, UTILIDADES E ALTERNATIVA SUGERIDA PARA OS PREÇOS DE ENERGIA ALEATÓRIOS .......................115 


\section{SUMÁRIO}

1.INTRODUÇÃ

1.1Definiçãa do problema de pesquisa ........................................................................................................17

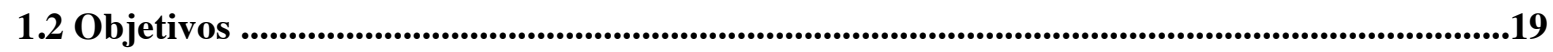

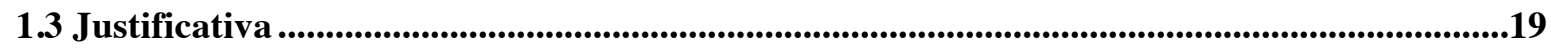

1.4 Organização do Trabalho...........................................................................................................................21

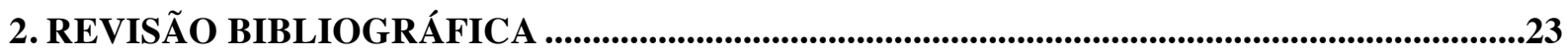

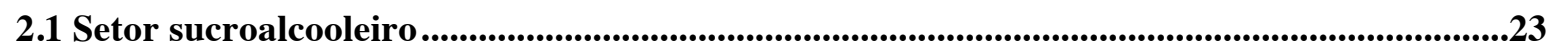

2.2 Aproveitamento da biomassa da cana-de-açúcar para cogeração de energia .......................26

2.3 Palhiço ..........................................................................................................................................................28

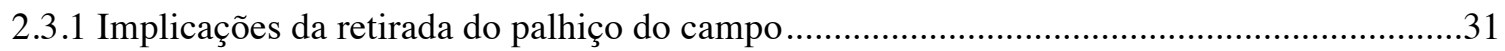

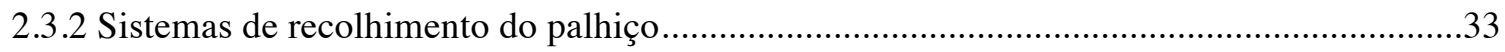

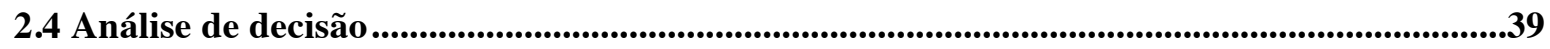

2.4.1 Compensações de preferências na escolha das alternativas para o recolhimento do palhiço:

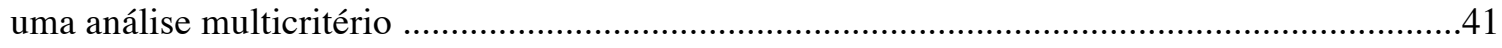

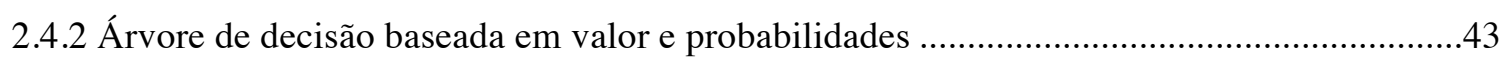

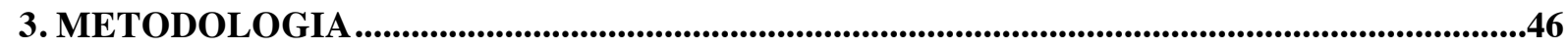

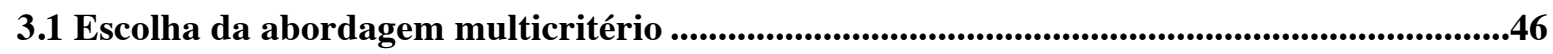

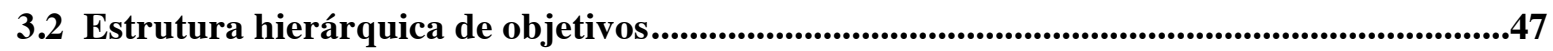

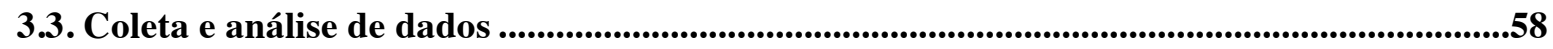

4. RESULTADOS E DISCUSSÕES..............................................................................................61

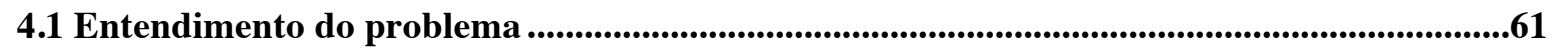

4.2 Definiçãa dos critérios....................................................................................................................61

4.3 Determinação das alternativas ......................................................................................................64

4.4 Avaliação das alternativas para cada critério ................................................................................64

4.4.1 Cálculo do valor esperado da receita das alternativas de recolhimento de palhiço ...............72

4.5 Hierarquização dos critérios .......................................................................................................76

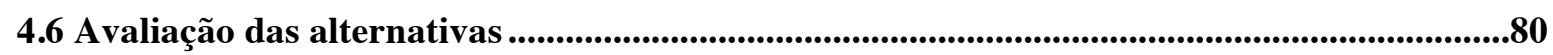

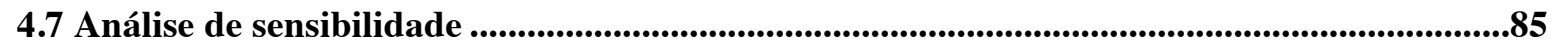

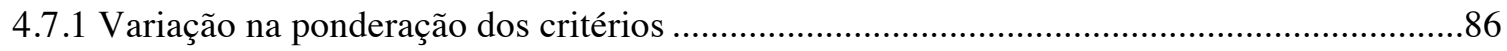

4.7.2 Método Rank Centroid (ROC) para ponderação dos critérios ................................................8

4.7.3 Análise de Monte Carlo para variação no preço da energia ....................................................90

4.8 Determinação da alternativa com melhor desempenho .............................................................94

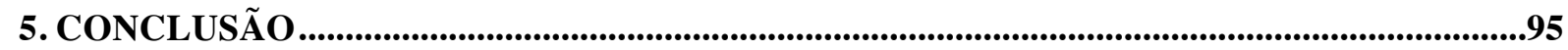


6. REFERÊNCIAS BIBLIOGRÁFICAS 


\section{INTRODUÇÃO}

A biomassa disponibilizada pela cultura da cana-de-açúcar pode ser uma alternativa para o aumento da geração de energia renovável. Essa biomassa é dividida por Corrêa Neto (2001) em duas categorias: o bagaço de cana, disponível na indústria após a extração do caldo e já utilizado como insumo energético; e o palhiço que fica disponível no campo após a colheita da cana e pode ser recuperado e transportado até a usina para fins de produção de energia.

Embora o palhiço e o bagaço de cana tenham características de combustível semelhantes, tornando-os adequados para a produção de energia, o palhiço, objeto de estudo desta pesquisa, tem o poder calorífico maior em relação ao bagaço. Cada tonelada de palhiço equivale a 1,8 toneladas de bagaço para geração de energia (KHATIWADA et al., 2015). Ripoli et al. (2000) também relatam as vantagens do palhiço ao bagaço ao afirmar que se houvesse a coleta de $50 \%$ de palhiço de toda área de cana da região Centro-Sul, a energia produzida poderia ser utilizada por nove milhões de pessoas de baixa renda, enquanto o bagaço na mesma região geraria energia para cinco milhões de pessoas nas mesmas condições. Portanto, o uso do palhiço, que até então é menos investigado que o bagaço como fonte de cogeração de energia, apresenta-se como uma oportunidade de pesquisa.

Problemas com o excesso de palhiço no solo são gerados a partir da consolidação da colheita mecanizada de cana sem queima, como a infestação por pragas e o retardamento da brotação devido aos efeitos de sombreamento, da barreira física e da diminuição da temperatura do solo (MACEDO, 2008). Assim, uma alternativa para consumir esse excesso de palhiço no solo é o recolhimento da biomassa no campo e a sua queima para a geração de energia elétrica, que pelas crises de 2001 e 2014 confirmaram o déficit da oferta de eletricidade e a ausência de aproveitamento de fontes renováveis de energia (TROMBETA, 2015). Além disso, o período de safra da cana-de-açúcar coincide com o período de baixos índices pluviométricos, o que torna o aproveitamento da energia elétrica do setor sucroalcooleiro uma alternativa viável para o sistema elétrico (SOUZA, 2002).

Nesse contexto, o palhiço vem sendo alvo de estudos econômicos (FURLAN et al., 2013; SOUZA e AZEVEDO, 2006), agronômicos (CARVALHO et al., 2016; HASSUANI et al., 2005) e ambientais (SHEEHAN et al., 2003; BLANCO-CANQUI, 2012; LISKA et al., 2014; DE FIGUEIREDO et al., 2015) a fim de identificar seu potencial uso como biomassa para cogeração de energia. Porém, o elevado custo associado ao recolhimento de palhiço constitui a explicação mais plausível para a pequena geração de excedentes de energia pelo 
setor por meio dessa biomassa (SOUZA e AZEVEDO, 2006). As alternativas de recolhimento mais em uso são a colheita integral, colheita parcial e o enfardamento. Na alternativa de colheita integral, a cana como um todo (colmo e palhiço) é transportada para a usina, onde em uma estação de limpeza se realiza a separação do palhiço. Esse sistema de recolhimento se caracteriza se caracteriza por manter desligados os ventiladores responsáveis pela limpeza do material colhido. Na colheita parcial, um dos sistemas de ventiladores da colhedora está ligado, e parte do palhiço fica no solo e a outra parte do palhiço é transportada junto com a cana para indústria sendo separados em uma estação de limpeza a seco. Já no processo de enfardamento, após a colheita mecanizada convencional, o palhiço é então deixado no campo por aproximadamente 15 dias para uma secagem natural, no intuito de aumentar a sua qualidade energética. Após esse período, o palhiço é enleirado, enfardado e transportado para a usina (HASSUANI et al. 2005).

Alguns trabalhos já discutiram e propureram soluções para o uso do palhiço desde a sua produção, recuperação e cogeração de energia (ROMÃO JUNIOR, 2009; GERMEK, 2014; FLORENTINO e SPADOTTO, 2006; TOLENTINO et al., 2007; FLORENTINO et al., 2011). Florentino et al. (2011) encontraram variedades de cana-de-açúcar que produzem palhiço que minimizem o custo em sua coleta e transferência para a usina e maximizem o balanço de energia em seu aproveitamento. Florentino e Spadotto (2006) apresentaram modelos com o objetivo de otimizar o processo de transferência do palhiço da cana-de-açúcar do campo para o centro de processamento, de tal maneira que maximize a quantidade de resíduos a ser colocada no caminhão, minimizando assim o custo com transporte. Germek et al. (2014) também definem a rota de menor custo. Já Romão Júnior (2009) propôs a utilização do palhiço como combustível para queima em caldeiras convencionais de alta pressão juntamente com o bagaço, verificando-se, então, um ganho na geração de excedentes de energia para comercialização e uma opção energeticamente e economicamente vantajosa.

Nota-se assim, que a maioria dos estudos envolvendo o palhiço tenta otimizar a rota de recolhimento, aliado a um menor custo para a indústria. No entanto, apesar das oportunidades para as usinas sucroalcooleiras, existem muitos fatores que devem ser considerados para a escolha da melhor alternativa no processo de obtenção do palhiço (RIPOLI, 2004). Segundo Pierossi e Fagundes (2013) os principais critérios, são: os custos com transporte, a umidade do palhiço durante o transporte, a qualidade do palhiço que pode ser medida em relação ao seu teor de impurezas minerais, e a eficiência de separação cana/palhiço. Também deve ser considerado o critério "custos de investimentos", que referente ao sistema de enfardamento é necessária a aquisição de máquinas enfardadoras, 
enleiradoras, caminhões e sistema de recolhimento dos fardos. Para a alternativa de sistema de colheita integral e parcial não é necessária esta estrutura de recolhimento, já que o palhiço é transportado com a cana (HASSUANI, 2005). Referente ao critério de "custos operacionais" destacam os custos com combustível, energia, mão-de-obra e manutenção dos equipamentos para cogeração (SMITHERS, 2014).

Furlan et al. (2013) consideram que o preço da energia no mercado influencia fundamentalmente a decisão de cogerar energia. Este preço, juntamente com a produtividade de energia referente à alternativa de recolhimento de palhiço, está ligado à receita da usina. Segundo eles, ao comparar três cenários diferentes, uma biorrefinaria flexível (capaz de alternar a produção de etanol de segunda geração e eletricidade), uma usina que gera etanol de primeira e segunda geração e uma usina que produz etanol e energia, notaram que a receita apresentada depende do cenário econômico e da produtividade do processo.

Portanto, percebe-se que são vários fatores relacionados a custos e variáveis agroindustriais que definem os métodos de recolhimento. Neste sentido, existe um trade off em relação a esses critérios e as alternativas de recolhimento de palhiço, sendo que cada critério se comporta melhor para uma determinada alternativa de recolhimento de palhiço.

Dessa forma, esta pesquisa propõe indicar a melhor opção dentre as alternativas de recolhimento de palhiço, a saber: colheita integral, colheita parcial e enfardamento. Diferente de outros estudos, nesta pesquisa é elaborado um modelo genérico multicritério para auxiliar empresas do setor sucroalcooleiro nas decisões sobre o recolhimento de palhiço para a cogeração de energia. Um modelo de decisão multicritério é proposto a partir do método SMART (Simple Multi-Attribute Ranking Technique) para avaliar as características econômicas e agroindustriais das principais alternativas de recolhimento de palhiço e indicar a opção ideal. Com o intuito de aplicar o modelo genérico, o modelo é aplicado com base em dados coletados de usinas do setor sucroalcooleiro.

\subsection{Definição do problema de pesquisa}

Khatiwada et al. (2015) afirmam que, ao apresentar um poder calorífico até mesmo superior ao do próprio bagaço, o palhiço da cana-de-açúcar passa a ser reconhecido como uma potencial biomassa adicional para o incremento da cogeração de energia nas centrais cogeradoras instaladas nas unidades industriais. Além disso, a geração de bioeletricidade pelas usinas a partir do palhiço tem se tornado não somente fonte de receita adicional da industrialização da cana-de-açúcar, mas um ponto chave às novas exigências do mercado de 
energia elétrica, cada vez mais sustentável. No entanto, apesar das oportunidades para a indústria sucroalcooleira, notam-se algumas barreiras no processo de obtenção do palhiço (RIPOLI, 2004). Os problemas logísticos e o alto custo de recolhimento são os principais entraves para a utilização dessa biomassa.

$\mathrm{Na}$ avaliação das alternativas apresentadas (colheita integral, colheita parcial e enfardamento), os principais fatores considerados na etapa de recolhimento e transporte do palhiço são: os custos com transporte, umidade do palhiço, teor de impurezas e eficiência de separação cana/palhiço. Os custos com transporte são maiores para o enfardamento, visto que uma nova colheita é realizada exclusivamente para o palhiço. A umidade do palhiço durante o transporte é menor para o recolhimento com fardos, pois para esta alternativa a colheita é feita aproximadamente dez dias depois da retirada da cana, o que reduz a umidade do palhiço. Já na colheita integral e parcial, a umidade do palhiço é maior, pois o transporte e envio para a usina é feito logo após a colheita, com o material ainda úmido. Em relação ao teor de impurezas minerais, uma grande quantidade de impurezas pode afetar negativamente a queima da biomassa. Essas impurezas são menores no palhiço resultante da colheita integral e parcial do que quando se processa o palhiço em fardos (PIEROSSI e FAGUNDES, 2013). A eficiência de separação cana/palhiço também representa um critério importante. Na colheita integral e parcial esse fator é medido pelo desempenho da estação de limpeza a seco, uma instalação grande, feita de forma customizada e cara, tanto quanto a aquisição como quanto a operação. Já em relação ao enfardamento, a eficiência de separação cana/palhiço depende do desempenho dos ventiladores da colhedora de cana, que ventila o material mais leve (palhiço) para o solo ao colher a cana-de-açúcar (RIPOLI, 2004).

Em relação aos custos de investimentos no sistema de enfardamento, essa alternativa requer uma estrutura dedicada. Deve-se investir em máquinas enfardadoras, enleiradoras, caminhões e sistema de recolhimento dos fardos. Para a alternativa de sistema de colheita integral e parcial não é necessária esta estrutura de recolhimento, já que o palhiço é transportado com a cana. A maior aquisição para esses sistemas é em relação ao sistema de limpeza a seco e o aumento de frotas para o transporte da cana juntamente com o palhiço (HASSUANI, 2005). Referente aos custos operacionais das alternativas de recolhimento de palhiço destacam os custos com combustível, energia, mão-de-obra e manutenção dos equipamentos (SMITHERS, 2014).

Embora vários critérios tenham que ser analisados conjuntamente para uma melhor tomada de decisão sobre a escolha da alternativa de recolhimento do palhiço, o fator "preço da energia" que altera ao longo do tempo e de acordo com a demanda deve ser levado em 
conta para a decisão de investir ou não nessas alternativas. Segundo Maia et al. (2016), o preço da energia é considerado um aspecto fundamental nas decisões de cogeração de energia, por ser muito volátil. Isso acontece pois o preço da energia depende de fatores externos ao setor sucroalcooleiro. Na safra, por exemplo, que coincide com o período de poucas chuvas, as usinas podem vender uma parcela maior da energia gerada com melhores preços. Em outros casos, em virtude de apagão, por exemplo, também se remunera mais pela energia. Desse modo, o preço da energia também é um critério determinante para a escolha da alternativa de recolhimento ideal para a cogeração de energia a partir do palhiço. Assim, a escolha das alternativas de recolhimento a partir da colheita integral, parcial ou enfardamento torna-se uma decisão complexa à medida que há incerteza e são vários os critérios que interferem nessa escolha.

\subsection{Objetivos}

O objetivo geral desta pesquisa é desenvolver um modelo para escolha da alternativa de recolhimento de palhiço da cana-de-açúcar para a cogeração de energia elétrica, sujeito aos critérios que condicionam o recolhimento dessa biomassa. É proposto um modelo multicritério, considerando critérios qualitativos e quantitativos das usuais alternativas de recolhimento e transporte de palhiço do campo até a indústria: colheita integral, colheita parcial e enfardamento.

Como objetivos específicos, busca-se:

- Definir a estrutura hierárquica de decisão com seus devidos objetivos (ou critérios) e alternativas;

- Analisar os possíveis preços de mercado da energia elétrica para, em seguida, avaliar o valor esperado da receita para cada alternativa de recolhimento de palhiço;

- Desenvolver o modelo genérico com base em valores convencionais usados por usinas do setor sucroalcooleiro e determinar a melhor alternativa de recolhimento de palhiço.

\subsection{Justificativa}

Em circunstâncias de tomadas de decisões, os decisores, ajudados por heurísticas simples ou de forma empírica, fazem escolhas tentando alcançar vários objetivos. Nesses casos, os tomadores de decisões tendem a aceitar o pior desempenho em alguns atributos em 
troca de um melhor desempenho em outros. Em particular, as heurísticas simples podem levar a decisões rápidas, envolvendo pouca análise, e são muitas vezes bem adaptadas para tarefas específicas quando o tempo é escasso (GIGERENZER; TODD, 1999). Contudo decisões mais estratégicas como o problema abordado nesta pesquisa justificam o uso de ferramentas mais elaboradas que permitem um tempo de análise maior. A análise de decisão ajuda os decisores a usar este tempo de forma eficiente para estruturar e esclarecer seus pensamentos (GOODWIN; WRIGHT, 2005). Neste caso, o modelo de análise de decisão irá auxiliar empresas do setor sucroenergético nas decisões sobre o recolhimento de palhiço para a cogeração de energia. Dessa forma, uma estrutura hierárquica de objetivos multicritério será elaborada para avaliar os principais métodos de recolhimento de palhiço, devido a sua capacidade para considerar vários aspectos relevantes na tomada de decisão (COBULOGLU e BÜYÜKTAHTAKIN, 2015; MICHAILOS et al., 2016).

De acordo com Prado (2007), além das dificuldades inerentes ao recolhimento do palhiço, existem os entraves relacionados à comercialização do excedente de energia elétrica. Estes problemas tangem principalmente fatores relacionados ao preço da energia, sugerindo uma análise sob o ponto de vista de incerteza, onde as decisões de investimento são fundamentais para o problema. Assim, essa pesquisa também irá utilizar a árvore de valor baseada em probabilidade como meio para obtenção do valor esperado da receita para cada alternativa de recolhimento de palhiço em vista dos possíveis preços da energia no mercado e da produtividade de energia para cada método de recolhimento.

A árvore de valor sob incerteza propicia ao tomador de decisão uma melhor visualização dos riscos, das opções e das vantagens financeiras presentes nas diversas alternativas de investimentos (CASAROTTO FILHO e KOPITTKE, 2010). Brealey et al. (2012) explicam que na utilização do método de árvore de valor é considerado o critério de valor monetário esperado, onde a melhor decisão para o projeto é determinada considerando os eventos e suas probabilidades de ocorrência. Para esta dissertação, serão tratadas como alternativas os métodos de recolhimento de palhiço, e como evento incerto os preços da energia elétrica no mercado. As probabilidades de ocorrência para cada evento irão determinar as chances de ocorrência de tais preços da energia.

Logo, assim como a maioria dos estudos envolvendo o palhiço tenta encontrar a melhor rota de recolhimento do campo para a indústria, esta pesquisa também sugere a alternativa que apresente o melhor beneficio frente aos custos e receitas dentre os métodos de recolhimento de palhiço considerados para avaliação. No entanto, diferente dos trabalhos 
descritos que estão baseadas em apenas fatores econômicos, esta pesquisa utiliza uma estrutura hierárquica de objetivos, considerando critérios diversos para selecionar a melhor opção, incluindo incerteza quanto ao preço da energia e aversão ao risco conforme o decisor.

Além disso, nota-se, uma carência de estudos que levam em consideração decisões posteriores à etapa de recolhimento do palhiço. De certa forma a alternativa de recolhimento escolhida influencia nessas decisões, pois o critério "valor esperado da receita" inclui os fatores de produtividade (referente a cada alternativa de recolhimento) e preço da energia. Assim, por meio deste critério busca-se identificar a viabilidade de comercialização da energia considerando o preço da energia no mercado.

Portanto, a tomada de decisão referente ao recolhimento de palhiço contribui para que os problemas relacionados principalmente aos fatores econômicos e agroindustriais apresentados pela literatura não se tornem uma barreira para o desenvolvimento da atividade de cogeração de energia.

\subsection{Organização do Trabalho}

A dissertação está estruturada em 5 capítulos, conforme a Figura 1:

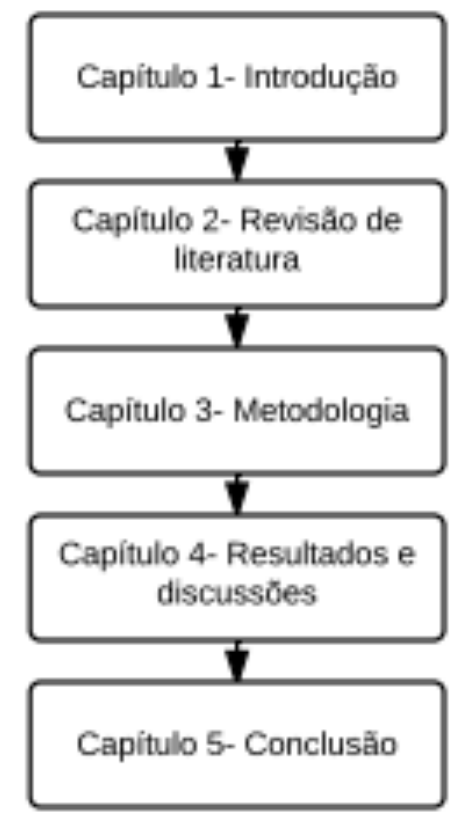

Figura 1: Estrutura da pesquisa

O Capítulo 1 apresenta a introdução sobre o contexto da pesquisa, os objetivos, a definição do problema, a justificativa e a estrutura do texto. 
O Capítulo 2 se refere à revisão de literatura. É apresentado um histórico sobre o setor sucroalcooleiro e sobre o tema do aproveitamento da biomassa da cana-de-açúcar para cogeração de energia, dando um enfoque maior ao palhiço, fonte de biomassa para cogeração de energia, e às suas alternativas de recolhimento. Os principais critérios para a decisão da opção de recolhimento do palhiço são descritos, bem como uma breve apresentação do tema de análise de decisão.

O Capítulo 3 apresenta a metodologia e as etapas para sua execução, a fim de responder o problema de pesquisa proposto.

No Capítulo 4 o modelo de análise de decisão sob o ponto de vista de gestores que represetam empresas convencionais do setor sucroalcooleiro. Os resultados são apresentados e discutidos. Análises de sensibilidade são realizadas para verificar o desempenho da solução sugerida.

Por último, o Capítulo 5 apresenta as conclusões obtidas acerca dos objetivos de pesquisa, as implicações acadêmicas e práticas desde trabalho, as limitações e as perspectivas para trabalhos futuros. 


\section{REVISÃO BIBLIOGRÁFICA}

\subsection{Setor sucroalcooleiro}

O setor sucroalcooleiro figura entre as mais tradicionais e antigas indústrias de processamento da biomassa no Brasil. As primeiras mudas de cana chegaram ao Brasil em 1532 na expedição de Martim Afonso de Souza e assim foram introduzidas na capitania hereditária de São Vicente (GONÇALVES, 2013). Dessa forma, a cana-de-açúcar é, desde o período colonial, a cultura mais amplamente desenvolvida e o açúcar foi um produto de exportação básico para a economia brasileira durante alguns séculos (PAIXÃO, 1997).

Depois de quase cinco séculos de ciclos de expansão e desaceleração, a importância histórica do setor reflete-se nos dias atuais, já que o Brasil é o maior produtor mundial de cana-de-açúcar. Por aproximadamente 400 anos, o principal produto extraído da cana-deaçúcar no Brasil foi o açúcar (MORAES e BACCHI, 2014). Com o desenvolvimento de novas tecnologias e novos tipos de comércio a indústria canavieira passou por renovações na qual desenvolveu a produção de etanol e posteriormente a geração de energia elétrica para o autoconsumo e a comercialização de seus excedentes, tornando-se um setor de alto impacto na economia brasileira, pois além de prover alimento esta indústria passou a ofertar combustível para veículos automotores e energia elétrica, ambos de baixo carbono, o que contribui para o desenvolvimento sustentável e coloca o Brasil em destaque no cenário mundial (UNICA, 2016).

De acordo com Moraes e Bacchi (2014), fatores relacionados à conjuntura internacional, como a crise de 1929 e a Segunda Guerra Mundial, impulsionaram a produção interna do etanol no Brasil com caráter emergencial e temporário. Um outro grande incentivo para os fazendeiros ampliarem a plantação de cana ocorreu no final do século XX, em 1975, quando foi criado o Programa Nacional do Álcool (Proálcool) com o objetivo de incentivar a utilização do álcool derivado da cana-de- açúcar. Esse programa estabeleceu linhas específicas de financiamento e estipulou uma paridade de preço entre o etanol e o açúcar cristal standard, estimulando a produção do etanol que, até então, era um subproduto menos valorizado (BNDES, 2008). Desde então, o preço começou a ser considerado um fator preponderante na avaliação de qualquer investimento na indústria sucroalcooleira. $O$ Proálcool, com incentivos do Banco Mundial, ampliou a atuação da indústria açucareira, possibilitando o crescimento do cultivo da cana-de-açúcar e a implantação de destilarias de 
álcool. Além disso, o programa contribuiu para o crescimento tecnológico do setor que na primeira década dobrou a área plantada de cana no país (GONÇALVES, 2013).

No âmbito internacional, de acordo com Bernardes (2016), a produção mundial de etanol revela uma crescente expansão desde 2007, apresentando uma variação de $87 \%$ entre 2007 e 2014. Nessa escala os EUA liderou o ranking em 2016, produzindo 15250 milhões de galões, seguido pelo Brasil com 7295 milhões de galões de etanol. Vale lembrar que a produção de etanol dos EUA vem do milho (STATISTA, 2018). Segundo Vaz (2015), o setor sucroalcooleiro no Brasil é uma das estratégias de projeção da imagem positiva do Brasil no mercado internacional, seja promovendo o país como o maior produtor de açúcar no mundo, seja destacando-o internacionalmente como pioneiro na produção de biocombustível economicamente viável, ou na introdução do Brasil como principal ator ao recente mercado das tecnologias limpas, o de cogeração de energia ou bioenergia. Entre as safras 2000/01 e 2016/17 a produção de cana no país passou de 254 milhões de toneladas para 690 milhões, apresentando variação em torno de $171 \%$ no período, respondendo a região Centro-Sul, que agrega os estados das regiões Sul, Sudeste e CentroOeste, por aproximadamente $90 \%$ desse volume (CONAB, 2016).

Se tratando de energia elétrica da cana-de-açúcar, o balanço de 2016, ano base 2015, apresentou que a oferta a partir da biomassa da cana aumentou entre os anos de 2014 e 2015 (Empresa de Pesquisa Energética - EPE, 2016). A Figura 2 mostra essa evolução.
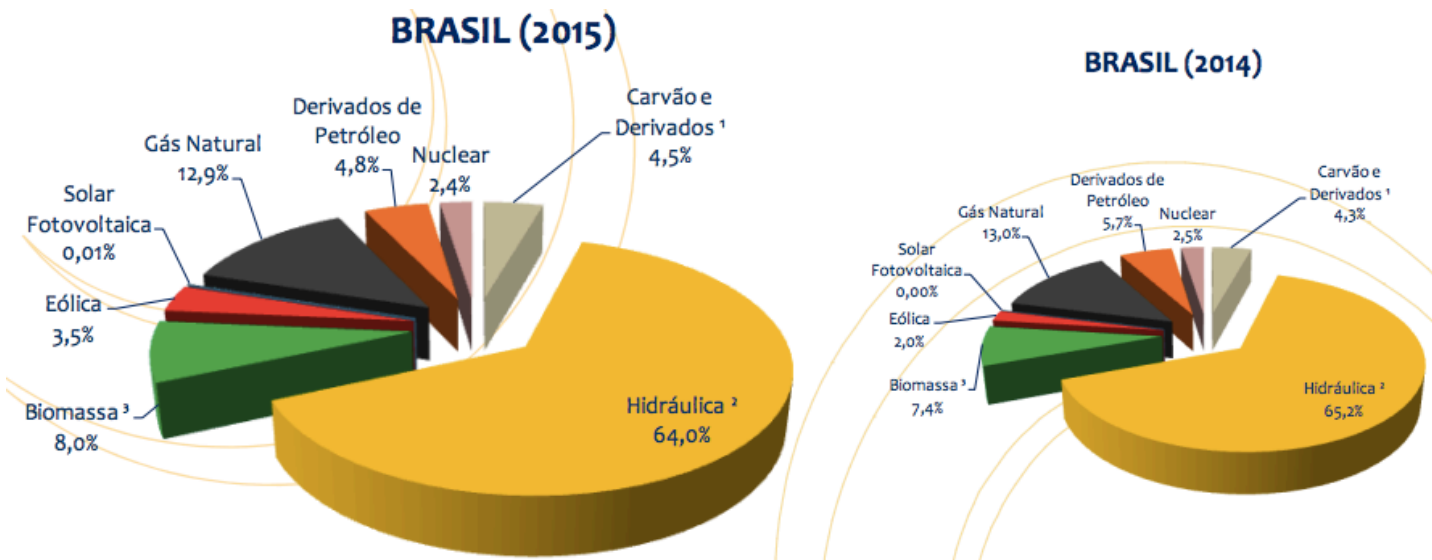

Figura 2: Matriz elétrica brasileira nos anos de 2015 e 2016. Fonte: EPE (2016)

Os resíduos da cana estão inseridos na repartição "biomassa". Assim, nota-se um aumento de $0,6 \%$ na matriz elétrica nacional para esta fonte de energia. As projeções da União da Indústria de Cana-de-Açúcar - UNICA (2010) indicam um potencial de oferta de energia elétrica a partir do palhiço e do bagaço de cana-de-açúcar de aproximadamente 13 
GW médios para a safra 2020/21. A Figura 3 mostra essas projeções de geração de energia a partir da biomassa de cana-de-açúcar.

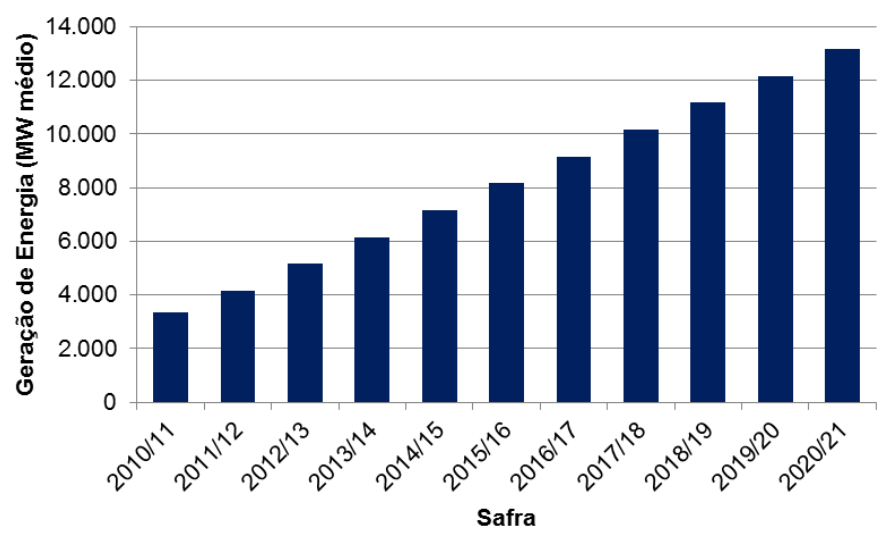

Figura 3: Projeções de geração de energia a partir da biomassa de cana-de-açúcar. Fonte: UNICA (2010)

Tais dados mostram que o setor poderá vir a contribuir para suprir a crescente demanda por energia no país. Segundo Trombeta (2015) as crises do setor elétrico brasileiro em 2001 e 2014 confirmaram o déficit da oferta de eletricidade e a ausência de novos empreendimentos como linhas de transmissão, usinas hidrelétricas, termelétricas, aproveitamento de fontes renováveis de energia e a utilidade do aumento da geração de energia elétrica a partir da cogeração. Além disso, segundo Prado (2007), o setor sucroalcooleiro tem características que o distinguem dos outros segmentos de cogeração no país. Ele é considerado autossuficiente em termos de geração de energia elétrica. Isso porque a grande maioria das usinas de açúcar e álcool produz a eletricidade que é consumida nos seus processos. Oliveira (2014) afirma que o setor sucroalcooleiro é o que tem maiores expectativas quanto à geração de excedentes de energia. Um ponto positivo é que o período de safra da cana-de-açúcar coincide com o período de baixos índices pluviométricos, o que torna o aproveitamento da energia elétrica do setor sucroalcooleiro uma ferramenta estratégica para o planejamento elétrico nacional. Além disso, no período de safra da cana-de-açúcar, maio a novembro, o consumo de energia elétrica é maior na região Centro-Sul, responsável por $90 \%$ da produção nacional, e, de forma inversa, nos meses de entressafra, dezembro a abril, o consumo de energia elétrica nesta região é menor (SOUZA, 2002). Projeções energéticas no Brasil indicam que até 2022 haverá uma diminuição da contribuição de 71\% para $65 \%$ da capacidade instalada das usinas hidrelétricas. As mesmas projeções indicam que outras fontes renováveis apresentarão um crescimento de 12,8\% para 20,8\% (EPE, 2013). Assim, cresce o interesse pela utilização do palhiço de cana-de-açúcar como combustível na 
produção de eletricidade para venda à rede, como alternativa à utilização de energia renovável (RIPOLI e RIPOLI, 2009).

Segundo Oliveira (2014), sob o aspecto ambiental, quando considerado o ciclo completo de cogeração de energia, a emissão de carbono é quase nula. Isso ocorre, porque a biomassa da cana-de-açúcar absorve o dióxido de carbono por meio da fotossíntese e depois lança na atmosfera pouco mais da quantidade absorvida. De acordo com Alexander (1973), o potencial fotossintético da cana é alto, pois ela é uma planta do tipo $\mathrm{C}_{4}$, capaz de eliminar as perdas de dióxido de carbono por meio da fotorrespiração das folhas, tendo assim um poder continuado de fixação de carbono.

Portanto, todos esses fatores (históricos, culturais, sociais, econômicos e ambientais) sugerem uma oportunidade de utilização da biomassa para produção de energia a partir da cana-de-açúcar, além da produção de açúcar e álcool. No entanto, para uma decisão de aproveitamento da biomassa exclusivamente para a cogeração de energia, vários fatores com base em custos e aspectos agroindustriais são levados em conta para uma análise complexa de investimentos pela indústria. Dessa forma, o aproveitamento da biomassa da cana-de-açúcar para cogeração de energia a partir do palhiço é o tema que norteia esta complexa análise de decisão.

\subsection{Aproveitamento da biomassa da cana-de-açúcar para cogeração de energia}

De acordo com Ripoli e Ripoli (2009) cresce o interesse pela utilização da biomassa de cana-de-açúcar como combustível na produção de eletricidade para venda à rede, devido ao interesse de aproveitamento de energia renovável. Isso ocorre, pois a geração de excedentes pelo setor sucroalcooleiro, segundo Souza (2003), apresenta vantagens comparativas, entre elas: caracteriza-se pela proximidade da demanda, podendo atender sistemas isolados; ocorre em períodos secos, quando a oferta hidrelétrica pode estar baixa; utiliza combustível e equipamentos locais; é relativamente menos agressora ao meio ambiente; o insumo é renovável; os investimentos em capital são relativamente menores; rápida entrada em operação comercial; e emprega mão-de-obra em zona rural.

Em relação à quantidade de biomassa residual da cultura da cana-de-açúcar, Corrêa Neto (2001) diz que ela depende da variedade cultivada, da idade da cultura, do estágio de corte, da situação climática, do sistema de colheita, da altura de corte dos ponteiros, entre outros. De acordo com Corrêa Neto e Ramon (2002), para as aplicações energéticas, onde se requer a disponibilidade contínua da biomassa, é preciso levar em conta que os resíduos se 
caracterizam por uma disponibilidade sazonal e podem precisar de armazenamento para os períodos fora da safra para garantir a geração de energia o ano todo.

Ripoli e Ripoli (2009) afirmam que o nível de fibra é um dos principais fatores de qualidade considerados ao avaliar a eficiência energética da cana-de-açúcar. Quanto maior a percentagem de fibra, menor a eficiência de extração, consequentemente, menos açúcar. No entanto, o melhoramento genético da cana-de-açúcar se apresenta como um novo divisor de águas: enquanto durante o século $\mathrm{XX}$ se buscou maior produtividade de açúcar, no século atual o novo modelo de cana deverá ser direcionado para alta produtividade de fibra (JOHNSON ET AL., 2007; HILL ET AL., 2006). De acordo com Innocente (2011), as plantas com mais fibras serão mais rústicas, ou seja, elas serão menos exigentes em solo, clima, água e nutrientes e mais resistentes a pragas e doenças, resultando em maior eficiência energética no seu cultivo, ou seja, maior unidade de energia produzida por energia gasta, se considerada toda a cadeia. Este é um parâmetro essencial, visto que a preservação ambiental e a sustentabilidade necessariamente terão que permear o processo.

Neste contexto, em relação aos fatores ambientais, no aspecto relacionado à poluição, de acordo com Seabra (2011), a cana-de-açúcar é uma fonte renovável de energia que pode gerar eletricidade com emissão de dióxido de carbono quase nulo após o balanço de emissões de carbono quando comparado com combustíveis convencionais. De acordo com Germek et al. (2014), o ciclo da cana retira da atmosfera cerca de oito vezes o CO2 que produz, enquanto a queima da gasolina produz três toneladas de $\mathrm{CO} 2$ por tonelada de combustível sem nenhuma compensação, e produz outros poluentes muito mais nocivos. Além disso, as emissões de óxidos de nitrogênio, óxidos de enxofre e particulados são muito menores que as emissões provocadas no uso de óleo combustível e carvão mineral. Assim, devido às vantagens ambientais que a geração de energia a partir da biomassa da cana-de-açúcar apresenta, o Brasil é destaque nos estudos de cultivo de biomassa para fins de produção de energia sob a ótica do Mecanismo de Desenvolvimento Limpo (MDL). O programa viabiliza que os países desenvolvidos realizem investimentos em projetos sustentáveis nos países subdesenvolvidos que variam desde reflorestamentos, substituição de combustíveis, uso final da energia, eficiência energética até a inserção de formas de geração de energia renováveis (ELLIS, et al., 2007). Assim, os países investidores recebem créditos de carbono correspondente à redução de emissões proporcionadas aos países em desenvolvimento que contabilizarão para atingir suas metas internas estabelecidas pelo Protocolo de Quioto. Uma análise feita por Silva Júnior et al. (2011) mostrou que dos 268 projetos de MDL aprovados até 2011, 40\% são projetos de cogeração de energia a partir da cana, demonstrando assim a relevância do desenvolvimento 
desse tipo de projeto no mercado de carbono brasileiro. Neste contexto, o intuito do MDL é que fontes de energia renováveis possam competir economicamente com as fontes tradicionais para poder ocupar uma fração significativa do mercado (PRADO, 2007).

Algumas características da biomassa da cana-de-açúcar são importantes para determinar a eficiência da produção de energia na usina. A seguir é apresentado um quadro comparativo com as principais características entre o palhiço e o bagaço (Quadro 1).

Quadro 1: Comparação entre as características do bagaço e palhiço

\begin{tabular}{cccc}
\hline Características & Bagaço & Palhiço & Autores \\
& & & \\
\hline Umidade & $50 \%$ & $15 \%$ & Linero (2013) \\
Poder calorífico inferior & $1710 \mathrm{kcal} / \mathrm{kg}$ & $3100 \mathrm{kcal} / \mathrm{kg}$ & Linero (2013) \\
$\mathrm{kg} /$ tonelada de colmo & $250 \mathrm{~kg}$ & $280 \mathrm{~kg}$ & CTC( 2017); \\
& & & Andreolli (2008) \\
\hline
\end{tabular}

Os valores do Quadro 1 podem ter uma pequena variação dependendo da variedade da cana-de-açúcar considerada, do seu grau de impureza e do sistema de cogeração. Pode-se notar que considerando o percentual de umidade de 50\% para o bagaço e 15\% para o palhiço, o poder calorífico inferior do palhiço segundo Linero (2013) é maior que a do bagaço. Além disso, em uma tonelada de cana produzida tem-se em média como resíduo $250 \mathrm{~kg}$ de bagaço e 280kg de palhiço (CENTRO DE TECNOLOGIA CANAVIEIRA - CTC, 2017; ANDREOLLI, 2008). De acordo com estudos feitos por Khatiwada et al. (2015) cada tonelada de palhiço equivale a 1,8 toneladas de bagaço para geração de energia. Isso quer dizer que o palhiço tem um grande potencial de geração de energia, assim como o bagaço. Porém, barreiras como o custo de transporte de palhiço do campo para usina impedem que o palhiço seja utilizado na mesma proporção que o bagaço pela indústria. Tais entraves serão detalhados nos próximos tópicos.

\subsection{Palhiço}

Segundo Ripoli e Ripoli (2009), o nome correto para este resíduo da colheita da canade- açúcar, sem queima prévia, é palhiço e não palha. Não se constitui apenas de folhas de cana com baixo grau de umidade, mas sim de folhas verdes, palha, ponteiros, com terra a eles agregados. Assim, o palhiço é uma biomassa residual da cana-de-açúcar constituída por folhas 
verdes, ponteiros e palha. Germek et al. (2014) destacam que o aproveitamento do palhiço nas usinas, por meio da queima em caldeiras para geração de vapor e, posteriormente, cogeração de energia, pode ser feito de forma isolada ou junto com o bagaço, proveniente do processamento da cana-de-açúcar na indústria e que já é utilizado pelas usinas como fonte de energia para alimentar a própria planta ou mesmo como excedente para comercialização.

O palhiço é fonte de energia renovável e abundante, sendo que um hectare de cana-deaçúcar pode fornecer entre 12 a 22 toneladas de palhiço (RIPOLI, 2001). Segundo o CTC (2017), 1 tonelada de cana tem potencial de produção de 2100 MJ de energia vinda do palhiço como mostra o Quadro 2, o que corresponde a 0,05 tonelada equivalente de petróleo (tep) (Quadro 2). De acordo com dados da Unica (2016), o Brasil produziu em 2016, 668 milhões de toneladas de cana, significando um potencial de geração de $33.10^{6}$ tep/ano com a utilização do palhiço. Essa produção representa 11,5\% da energia primária do Brasil, visto que a produção primária do Brasil em valores absolutos é de $286.10^{6}$ tep/ano (EPE, 2017).

Quadro 2: Energia da cana-de-açúcar. Fonte: CTC (2017)

\begin{tabular}{cc}
\hline 1 tonelada de cana (Colmos) & Energia (MJ) \\
\hline $250 \mathrm{~kg}$ de bagaço $(50 \%$ umidade) & 2000 \\
$280 \mathrm{~kg}$ palhiço $(50 \%$ umidade) & 2100 \\
Total & $\mathbf{6 4 0 0}$ \\
\hline
\end{tabular}

Segundo Oliveira (2014), o uso dessa biomassa para fins produtivos e econômicos tem mobilizado pesquisadores de universidades, gerentes e diretores de usinas com o intuito de avaliar a viabilidade da utilização do palhiço para fins energéticos. Esses estudos vêm apresentando que os principais gargalos para que o potencial de geração e máxima utilização dessa matéria-prima sejam efetivos são: a amplitude dos níveis de tecnologia para cogeração, o domínio do manejo adequado do palhiço, a escassez de investimentos e o cenário de recessão econômica (TROMBETA, 2015).

Um projeto que busca identificar e solucionar esses gargalos é o Projeto Sugarcane Renewable Electricity (SUCRE). De acordo com SUCRE (2017) o projeto busca solucionar os problemas que possam impedir as usinas parceiras de gerarem eletricidade, de forma plena e sistemática, utilizando o palhiço disponível com a colheita de cana sem queimar. Dentre os principais objetivos, o programa se dedica em aumentar significativamente a produção de eletricidade com baixa emissão de gases do efeito estufa (GEE) por meio do uso do palhiço da 
cana. A iniciativa é promovida pelo Laboratório Nacional de Ciência e Tecnologia do Bioetanol (CTBE), que atuará junto a usinas parceiras para desenvolver soluções que elevem a geração à plenitude. O projeto é financiado pelo Fundo Global para Meio Ambiente e gerido pelo Programa das Nações Unidas para o Desenvolvimento (PNUD).

Assim, de acordo com SUCRE (2017), a equipe trabalhará na solução dos problemas que impedem as usinas de gerarem energia a partir do palhiço. $\mathrm{O}$ projeto atuará em sete frentes, buscando os seguintes resultados:

- Operacionalização da tecnologia para coleta e conversão do palhiço de cana em eletricidade;

- Demonstração da viabilidade econômica do palhiço para cogeração de energia;

- Avaliação dos efeitos da coleta de palhiço no ciclo de cultivo e colheita, de modo a garantir integridade ambiental e sustentabilidade em longo prazo;

- Divulgação das diretrizes ambientais e econômicas para utilização do palhiço da canade-açúcar em todo setor sucroalcooleiro;

- Formulação do arcabouço legal e regulatório para promover o uso sustentável do palhiço de cana para produção de eletricidade e venda à rede;

- Monitoramento do projeto, aprendizado, gestão adaptativa e avaliação;

- Gerenciamento do projeto.

Segundo Carvalho et al. (2016) o excesso de palhiço no solo devido à proibição da queima da cana contribui para o aumento da infestação de pragas. Sem a queima, proibida pela legislação ambiental, o palhiço cria condições favoráveis para parasitas, comprometendo a safra seguinte (DIAS, 2013). No entanto, parte desse resíduo deve permanecer no solo para que cumpra suas funções ecossistêmicas: proteção das características do solo, manutenção da umidade, controle da erosão, infestação de plantas daninhas, matéria orgânica, microrganismos e controle de gramíneas anuais (KUVA et al., 2008). Dessa forma, com a remoção controlada do palhiço será possível, ao mesmo tempo, mitigar tais inconvenientes e ainda produzir bioenergia.

Ripoli (2002) desenvolveu modelos matemáticos relativos ao equacionamento dos balanços energético e econômico do palhiço de cana- de-açúcar. Para a validação dos modelos, o autor realizou ensaios de campo na Usina Santa Lídia, no município de Ribeirão Preto, SP. Por fim, com a aplicação dos modelos desenvolvidos, constatou-se que a substituição do bagaço pelo palhiço nas usinas de açúcar pode ser altamente vantajosa. $\mathrm{O}$ autor apresentou um desenvolvimento matemático cujo resultado final é a equação que fornece uma estimativa do 
número de pessoas que podem ser atendidas por energia elétrica proveniente da biomassa do palhiço de cana-de-açúcar. Ao recolher apenas 50\% de palhiço de toda área de cana da região Centro-Sul, pode-se produzir energia para nove milhões de pessoas de consumo de baixa renda. $\mathrm{O}$ bagaço na mesma região geraria energia para cinco milhões de pessoas nas mesmas circunstâncias.

Germek et al. (2014) ao avaliar o potencial de geração de energia do palhiço, desenvolveu equações para serem empregadas pelo setor sucroalcooleiro em função das características locais e regionais para avaliar se é vantajoso o aproveitamento do palhiço como fonte energética complementar ao bagaço. Por fim, as equações lineares desenvolvidas neste estudo mostraram que o potencial de incremento de energia de biomassa gerada pelo uso do palhiço adicional ao bagaço é da ordem de 5,59\% a 55,94\%, que depende de cada unidade industrial, das suas características próprias e do percentual de recolhimento adotado.

\subsubsection{Implicações da retirada do palhiço do campo}

Segundo Furlani Neto et al. (1997) a deposição e manutenção de palhiço sobre a superfície do solo, mesmo contribuindo com a sua conservação, podem causar problemas relacionados ao manejo da cultura. Alguns desses problemas podem ser citados: dificuldades durante as operações de cultivo e adubação da soca (AUDE et al.,1993), retardamento da brotação inicial da soqueira devido aos efeitos de sombreamento, da barreira física e da diminuição da temperatura do solo, e aumento das populações de pragas que se abrigam e se multiplicam sob o palhiço (MACEDO et al., 2003). Além disso, o grande volume de palhiço sobre a cana dificulta o seu perfilhamento, causando falhas na rebrota. Ávarez e Castro (1999) citam o aumento de pragas como a cigarrinha, as irregularidades da brotação da cana-deaçúcar e a queda de produtividade da cana como os pontos negativos da permanência do palhiço no solo. Em relação às pragas, o palhiço influencia na sua presença na área de plantio. Algumas pragas da cana-de-açúcar podem causar impactos significativos, apresentando também um efeito notável nos processos industriais por reduzir a qualidade da cana (RAVANELI et al., 2011). O período de maior atividade para os insetos coincide com os meses quentes e úmidos (outubro a abril no hemisfério sul). Assim, o palhiço funciona como um abrigo para essas pragas, além de auxiliar na manutenção do ambiente úmido do solo, propício para tais insetos. Em alguns casos, em regiões frias, a manutenção do palhiço no solo também pode dificultar a rebrota da cana-de-açúcar, reduzindo sua produtividade (CAMPOS 
et al., 2010), isso acontece porque a manutenção do palhiço reduz a temperatura do solo e atua como uma barreira física à brotação da cana-de-açúcar.

Por outro lado, de acordo com Carvalho et al. (2016), a permanência da biomassa do palhiço no solo fornece alguns benefícios ao ecossistema, como: biodiversidade para o solo, mais nutrientes, acúmulo de carbono, controle da erosão e das infestações de ervas daninhas. Outras vantagens de manter uma parte do palhiço no campo são as seguintes: maior retenção de água e, consequentemente, da umidade (responsável pelas propriedades físicas, químicas e biológicas), e, também, a estabilização dos constituintes do solo, melhorando suas características físicas e químicas, facilitando, assim, a aeração, infiltração de água e sua retenção. Em um estudo de simulação de chuvas, Silva et al. (2012) observaram que, nos lotes de cana-de-açúcar onde a cobertura total do solo foi mantida, a erosão foi reduzida em $92 \%$ em relação a uma situação de controle onde toda o palhiço foi removido. Utilizando a mesma abordagem, Sousa et al. (2012) apontou que a manutenção de palhiço de 7 t/ha poderiam potencialmente reduzir as perdas de solo em uma média de 85\%, em áreas com maior inclinação de terreno. No entanto, a manutenção de níveis de palhiço superiores a este não conduziu a uma diferença significativa nas perdas de solo em diferentes inclinações. Abrão (2012) verificou que a macrofauna do solo também foi fortemente influenciada pela quantidade de palhiço presente no campo, demonstrando maior densidade, riqueza e diversidade quando o solo estava coberto por mais de 7,6 t/ha de palhiço. Resultados semelhantes foram relatados por Abreu et al. (2012), que observou maior densidade de indivíduos quando mais de 5,1 t/ha de palhiço foi mantida na superfície do solo. A maior diversidade da macrofauna do solo pode ser atribuída a altos níveis de nutrientes no solo sob cultivo de cana-de-açúcar (FRANCO et al., 2016).

Dessa forma, segundo Santos et al. (2014) é preciso encontrar uma quantidade de equilíbrio para não prejudicar as características do solo e nem a viabilidade do palhiço para a cogeração. Segundo Carvalho et al. (2016), a tomada de decisão referente à quantidade de palhiço ideal que deve permanecer no solo está associada à quantidade mínima de palhiço que deve estar presente na área plantada e não à porcentagem de palhiço a ser retirado, visto que a variação de palhiço em cada plantação é grande. Os canaviais brasileiros produzem quantidades de palhiço que variam de 8 a 30 toneladas por hectare por ano (TRIVELIN et al., 2013; HASSUANI et al., 2005; VITTI et al., 2008).

Em geral, a literatura indica que a maior parte dos benefícios ambientais é alcançada quando pelo menos 7t/ha de palhiço seco são mantidos na superfície do solo (MARTINS FILHO et al.,2009). Para Hames et al. (2003) e Santos et al.(2014) a tomada de decisão sobre 
a remoção de palhiço deve englobar as condições de solo e clima vigentes em cada local pois a produção de palhiço nos campos de cana-de-açúcar variam de acordo com a variedade da cultura, condições climáticas e práticas de manejo do solo. Assim, análises integradas, que englobem os benefícios agronômicos, econômicos e ambientais devem ser priorizadas (CARVALHO et al., 2016). Dessa forma, os esforços de modelagem são de suma importância para avaliar as taxas de remoção de palhiço considerando os diversos indicadores envolvidos nesta equação complexa, de modo que uma taxa de recuperação de palhiço precisa poderia ser fornecida aos produtores e à indústria para uma maior sustentabilidade.

\subsubsection{Sistemas de recolhimento do palhiço}

Embora o uso de palhiço para cogeração de energia seja uma oportunidade para a indústria, nota-se que algumas dificuldades estão presentes no processo de seu aproveitamento. De acordo com Michelazzo e Braunbeck (2008), problemas logísticos e o seu alto custo de recolhimento são os principais entraves para a utilização dessa biomassa. As alternativas de recolhimento atualmente mais em uso são o transporte do palhiço junto com a cana picada colhida mecanicamente que se faz pelos sistemas de colheita integral ou parcial e o enfardamento do palhiço, realizado em operação posterior à colheita mecanizada da cana realizada convencionalmente. Porém, também existem outras alternativas menos utilizadas, como o sistema de colheita a granel, em que o palhiço é picado por uma forrageira e transportado a granel para a indústria. Este não será considerado no modelo do estudo devido à sua mínima utilização pelas usinas.

As alternativas de recolhimento do palhiço consideradas no presente estudo são detalhadas a seguir:

1) Sistema de colheita integral: A cana-de-açúcar é coletada juntamente com o palhiço, por meio do desligamento dos sistemas de limpeza da colhedora, sendo o material transportado à usina nos mesmos veículos utilizados na colheita convencional (INNOCENTE, 2011). Em seguida, o palhiço deve ser separado da cana. Uma das formas é por meio de uma estação de limpeza a seco. Nesse sistema, a limpeza da cana-de-açúcar é realizada por meio de uma forte corrente de ar que separa os colmos do palhiço. Segundo Germek (2005), essa limpeza deve ser feita, pois além de separar o palhiço da cana, o palhiço contém particulados de diferentes tamanhos e formas que causam redução na eficiência da combustão pela possibilidade de obstrução do sistema de alimentação das caldeiras. Assim, o sistema de limpeza a seco ajuda na redução de impurezas do palhiço, contribuindo para a diminuição do desgaste em 
equipamentos e maior aproveitamento do palhiço. A Figura 4 apresenta o sistema de limpeza a seco.

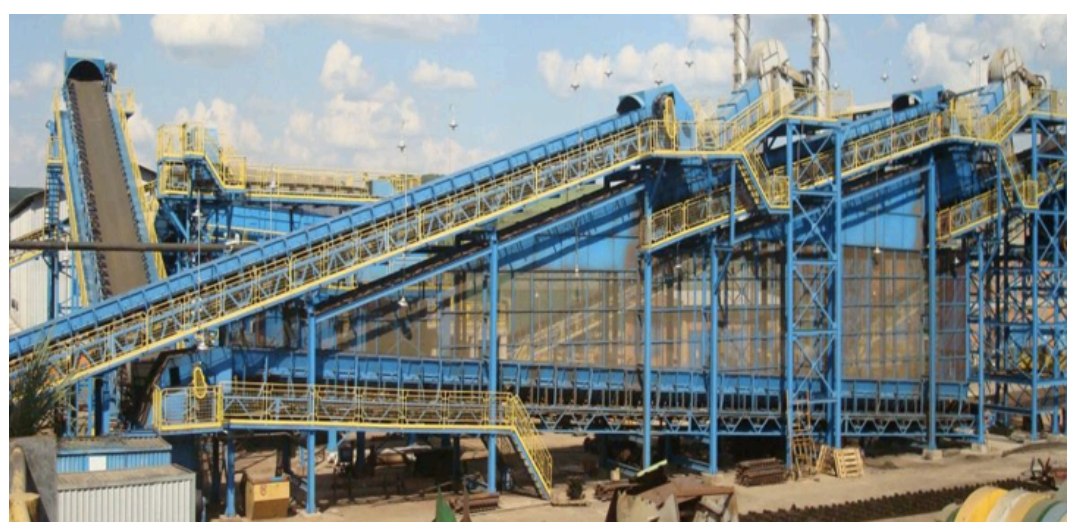

Figura 4: Sistema de limpeza a seco. Fonte: CTC(2017)

Como consequência da colheita integral, o palhiço juntamente com os rebolos comprometem a carga de viagem para a usina, devido à uma redução de densidade, requerendo uma maior infraestrutura de transporte. Hassuani et al. (2005) apresentam resultados em que a carga média transportada é reduzida a menos da metade nas condições de colheita integral.

Outra consequência da colheita integral, porém esta positiva, é a diminuição de perdas de cana devido ao desligamento do sistema de limpeza da colhedora. No sistema convencional, ao realizar a limpeza da cana, muitos rebolos chocam contra o extrator de limpeza e são jogados ao campo, causando perdas. Visto que na colheita integral o sistema de limpeza é desligado, as perdas são reduzidas. Além disso, o gasto de combustível neste sistema também é reduzido devido ao desligamento do sistema de limpeza (SILVA, 2011).

2) Sistema de recolhimento parcial do palhiço: Esta alternativa de recolhimento é bem semelhante à colheita integral no que se refere aos equipamentos utilizados e às operações. No entanto, na colheita parcial alcança-se níveis diferentes de biomassa remanescente no campo. De acordo com Hassuani et al. (2005), neste tipo de recolhimento do palhiço, o sistema secundário de limpeza da colhedora está desligado e o sistema primário trabalha com uma velocidade menor, assim, parte do palhiço é transportado junto com a cana e depois, na indústria, eles são separados em uma estação de limpeza a seco. É possível de certa forma dosar a quantidade de palhiço mantida no campo, por meio da regulagem do sistema de limpeza, visando atingir uma quantidade de palhiço sobre o solo para se obter os benefícios agronômicos, retirando-se o excedente para envio para a indústria para geração de energia 
(SILVA, 2011).

A colheita parcial do palhiço realizada desta maneira possibilita uma maior facilidade operacional visto que interfere menos na operação cotidiana na usina. Além disso, a densidade de carga é impactada diretamente pela diminuição da quantidade de palhiço, desta forma, em termos de transporte, as cargas transportadas para a usina têm uma maior densidade em comparação ao sistema de colheita integral.

Segundo Silva (2011), outro ponto positivo da colheita parcial é a eficiência de separação cana/palhiço. Neste tipo de colheita apenas as folhas verdes e folhas secas são transportados juntos com os colmos para a usina. Essa porção do palhiço é diferenciada dos colmos em termos de massa, ao contrário dos ponteiros, que possuem semelhança física com os rebolos de cana, e, uma vez que a separação na estação de limpeza ocorre por diferença física, a eficiência de separação é comprometida. A Figura 5 apresenta a efíciência de separação cana/palhiço no sistema de limpeza a seco para a colheita convencional (integral) e para a colheita parcial pós-chuva e no tempo seco.

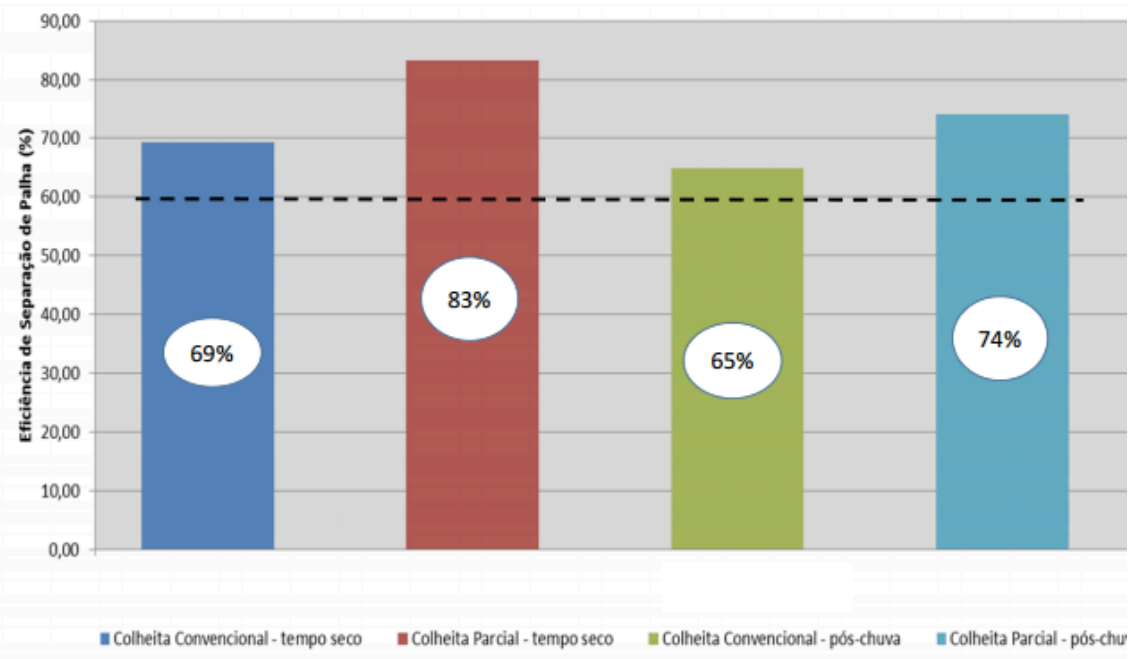

Figura 5: Eficiência de separação cana/palhiço no sistema de limpeza a seco. Fonte: CTC(2017)

A eficiência de separação do palhiço pelo sistema de limpeza a seco varia conforme o tipo de colheita e a umidade do palhiço. A Figura 5 mostra que a eficiência de separação pelo sistema parcial é melhor que na colheita integral, pois são coletadas menos impurezas. Além disso o tempo seco melhora a eficiência da separação, visto que a umidade interfere negativamente no processo. Isso acontece pois a parte de palhiço que fica na carga é a mais leve. Como a separação é feita por meios físicos, é mais fácil separar o palhiço mais leve dos rebolos de cana mais pesados.

3) Enfardamento: Durante a colheita de cana, o palhiço é separado dos colmos a partir de um 
sistema de ventilação composto por dois extratores localizados na colhedora de cana picada e os valores usuais de impurezas vegetais (palhiço) encontrados são entre 5 e $6 \%$, deixando a maior parte do palhiço no solo (PELLEGRINI, 2002). De acordo com Innocente (2011), o palhiço enfardado consiste em seu recolhimento, cerca de dez dias após a colheita, ou seja, existe um tempo para o palhiço secar. Depois disso, realiza-se o aleiramento desse palhiço, seguido do enfardamento e do transporte para a usina. A Figura 6 apresenta as etapas do processo de enfardamento.

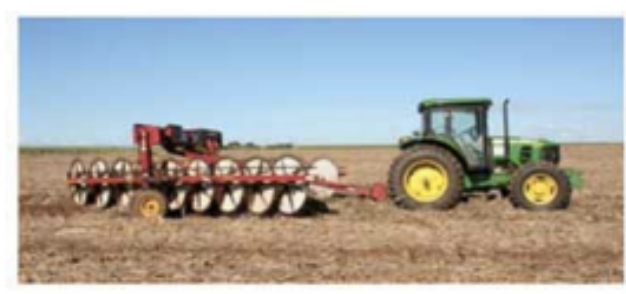

a) Aleiramento

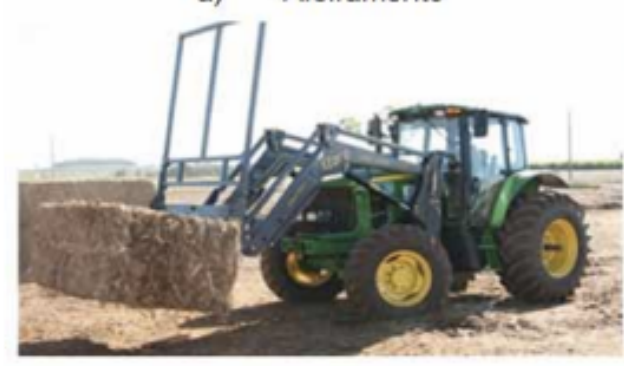

c) Carregamento

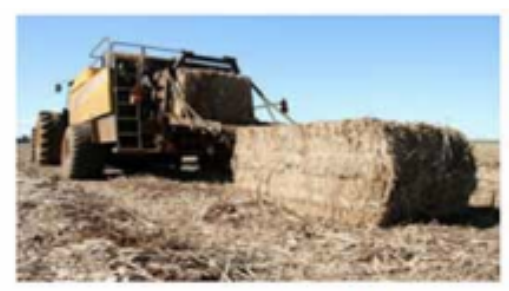

b) Enfardamento

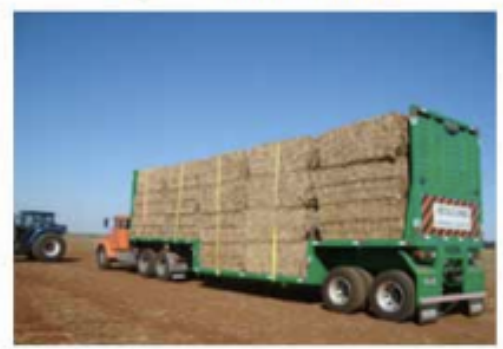

d) Transporte

Figura 6: Etapas do enfardamento. Fonte: Selegato (2012)

A etapa "a" corresponde ao aleiramento, que consiste no agrupamento do palhiço em leiras. Em seguida, na etapa "b" a enfardadora recolhe o palhiço contido na leira, compactando-o em fardos. Os fardos são depositados no solo à medida que são produzidos e o recolhimento é realizado pela carreta recolhedora, como mostra a etapa "c" e então são carregados nos equipamentos rodoviários que os transportarão até a usina (etapa "d"). Segundo o CTC (2017), este sistema apresenta uma maior eficiência logística e redução nos custos de operação, além de uma melhor relação entre os indicadores custo/benefício do palhiço.

A figura 7 apresenta as etapas e opções de sistema de recolhimento do palhiço. 


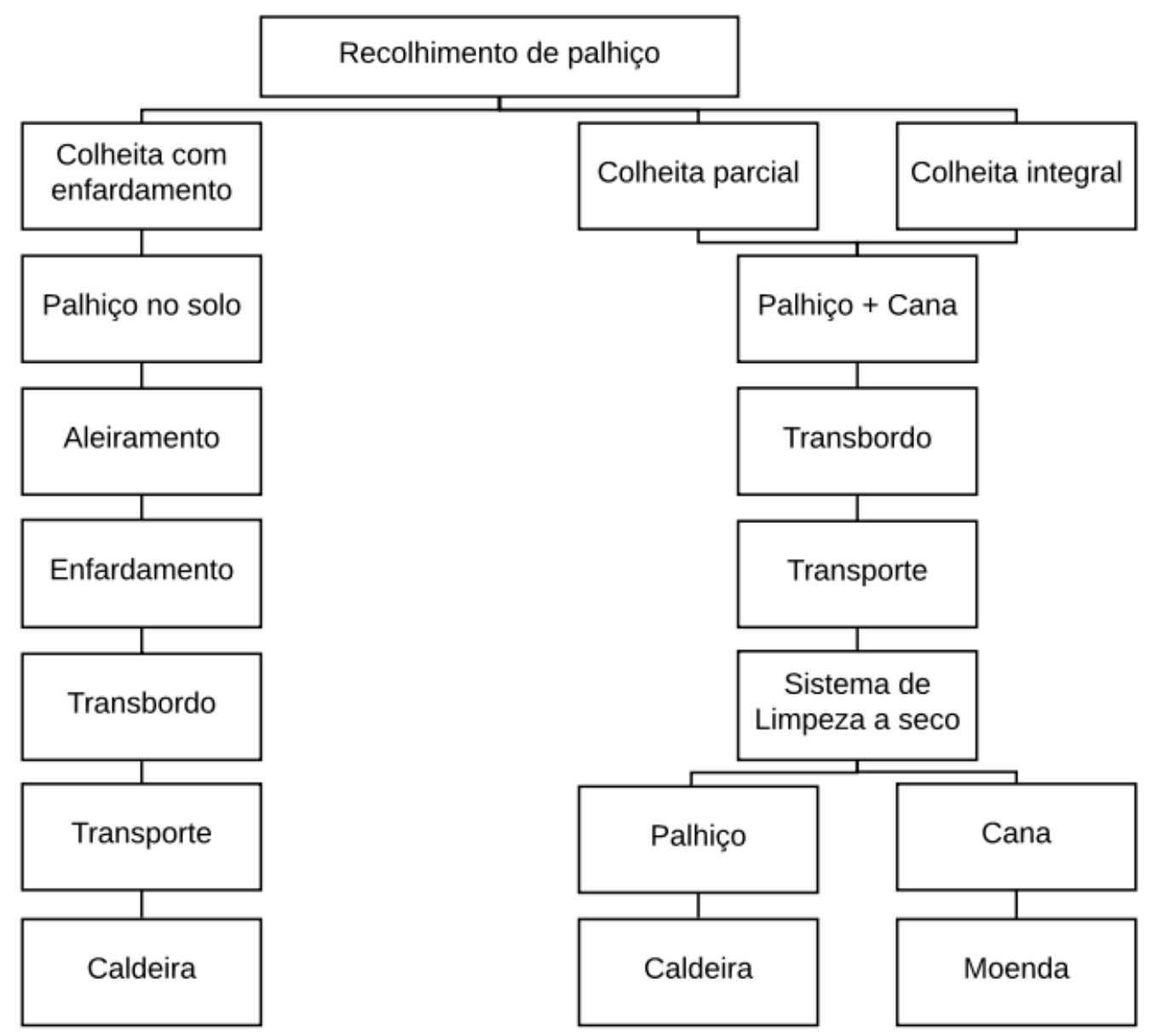

Figura 7: Alternativas e etapas do recolhimento de palhiço

Diversos estudos foram desenvolvidos para definir o melhor sistema de recolhimento deste material para ser empregado na cogeração de energia. Para Ripoli (2002) o sistema de recolhimento por enfardamento têm algumas desvantagens: emprega combustível nas operações de enleiramento, de recolhimento propriamente dito, de transporte e de descarregamento do palhiço e, além disso, produz compactação do solo e uma porcentagem de terra no material que irá afetar no teor de energia contida no palhiço. Por outro lado, os sistemas de colheita integral e parcial compactam menos o solo por utilizarem uma única passagem na operação de corte e colheita, evitando a agregação de terra no material a ser transportado. Entretanto, segundo Ripoli (2004) estes sistemas exigem a limpeza e prétratamento das impurezas de origem vegetal antes do processo de extração, junto à unidade industrial. O processo de limpeza tem baixa eficiência de separação e consumirá energia com o acionamento de motores elétricos.

Germek et al. (2014) mostraram que estudos desenvolvidos no grupo Cosan- SP tiveram como resultado que o melhor sistema é a colheita integral do canavial em termos de custos e eficiência energética. Segundo eles, para a adoção da sistemática de colheita integral 
existe a necessidade da instalação na unidade industrial de equipamentos de pré-limpeza já disponíveis comercialmente e ainda podem reduzir os custos das colhedoras por não necessitar de limpeza no campo e nem de transporte dedicado ao palhiço. Por outro lado, segundo Ripoli (2004), a estação de limpeza a seco é uma instalação grande, feita de forma customizada e cara, tanto quanto a aquisição como quanto a operação.

Cardoso et al. (2017) avaliaram os custos de recolhimento de palhiço considerando o sistema de recolhimento com fardos e colheita integral. Eles calcularam os benefícios que o recolhimento do palhiço com colheita integral pode ter com a "Lei da balança", lei que limita o peso bruto total combinado das atuais composições canavieiras, pois uma vez que o palhiço tem menor densidade, ele pode ocupar os espaços vazios no transporte. Os resultados mostraram que para o recolhimento de $50 \%$ do palhiço, a diferença de custos entre fardos e colheita integral é de $44 \%$, considerando a Lei da balança. Dessa forma, a Lei da Balança pode ter seu impacto no custo de transporte reduzido com o recolhimento de palhiço com colheita integral, e servir como incentivo para a utilização deste sistema.

Por outro lado, Smithers (2014) relata que os custos de levar o palhiço até a usina incluem custos de coleta do palhiço, separação do palhiço da cana, transporte (52\% do custo total) além de custos dos impactos ambientais, que equivalem a 43,2\% dos custos totais. Estes incluem a perda de nutrientes, custos com herbicidas para repor nutrientes e compactação do solo. Quando todos estes custos são levados em conta, Hassuani et al. (2005) conclui que a separação do palhiço e da cana no campo é $41 \%$ mais barata comparada ao sistema de colheita integral e parcial. A baixa densidade do transporte do sistema de colheita integral é a principal causa desse aumento de custo.

Esses estudos, em sua maioria, consideram o custo como o principal critério de análise. O presente estudo avalia vários critérios ao mesmo tempo, além do custo, levando em consideração a escolha do decisor, para cada uma das alternativas de recolhimento. Para compor os critérios relevantes para a análise de decisão, o Quadro 3 apresenta as principais características que diferenciam os principais sistemas de recolhimento do palhiço, sistema de colheita integral, parcial e enfardamento. 
Quadro 3: Diferenças dos sistemas de recolhimento integral, parcial e enfardamento

\begin{tabular}{|c|c|c|c|}
\hline Parâmetros & $\begin{array}{c}\text { Sistema de colheita } \\
\text { integral }\end{array}$ & $\begin{array}{c}\text { Sistema de colheita } \\
\text { parcial }\end{array}$ & Enfardamento \\
\hline Quantidade de colheitas & Uma colheita & Uma colheita & Duas colheitas \\
\hline Umidade do palhiço & $\begin{array}{l}\text { Palhiço recolhido } \\
\text { com maior umidade }\end{array}$ & $\begin{array}{l}\text { Palhiço recolhido } \\
\text { com maior umidade }\end{array}$ & $\begin{array}{l}\text { Palhiço recolhido } \\
\text { com menor umidade }\end{array}$ \\
\hline Sistema de limpeza & $\begin{array}{c}\text { Necessário sistema de } \\
\text { limpeza a seco }\end{array}$ & $\begin{array}{l}\text { Necessário sistema } \\
\text { de limpeza a seco }\end{array}$ & $\begin{array}{c}\text { Não necessita do } \\
\text { sistema de limpeza a } \\
\text { seco }\end{array}$ \\
\hline Densidade no transporte & $\begin{array}{l}\text { Menor densidade no } \\
\text { transporte }\end{array}$ & $\begin{array}{l}\text { Densidade } \\
\text { intermediária no } \\
\text { transporte }\end{array}$ & $\begin{array}{l}\text { Maior densidade no } \\
\text { transporte }\end{array}$ \\
\hline Consumo de combustível & $\begin{array}{l}\text { Menor gasto com } \\
\text { combustível }\end{array}$ & $\begin{array}{l}\text { Menor consumo de } \\
\text { combustível }\end{array}$ & $\begin{array}{l}\text { Alto consumo de } \\
\text { combustível }\end{array}$ \\
\hline Compactação do solo & $\begin{array}{l}\text { Compactação média } \\
\text { do solo }\end{array}$ & $\begin{array}{c}\text { Menor compactação } \\
\text { do solo }\end{array}$ & $\begin{array}{c}\text { Maior compactação } \\
\text { do solo }\end{array}$ \\
\hline $\begin{array}{c}\text { Palhiço remanescente no } \\
\text { solo após colheita }\end{array}$ & $\begin{array}{c}\text { 1,4 t/ha (Hassuani et } \\
\text { al., 2005) }\end{array}$ & $\begin{array}{c}7 \text { t/ha (Hassuani et } \\
\text { al., 2005) }\end{array}$ & $\begin{array}{c}16 \mathrm{t} / \mathrm{ha} \text { (Hassuani et } \\
\text { al., 2005) }\end{array}$ \\
\hline $\begin{array}{c}\text { Perda de rebolos no } \\
\text { transporte }\end{array}$ & $\begin{array}{c}1,4 \% \text { (Hassuani et al., } \\
2005)\end{array}$ & $\begin{array}{c}\text { 1,6\% (Hassuani et } \\
\text { al., 2005) }\end{array}$ & $\begin{array}{c}2,7 \% \text { (Hassuani et } \\
\text { al., 2005) }\end{array}$ \\
\hline
\end{tabular}

\subsection{Análise de decisão}

Análise de decisão é um esforço para aplicar conceitos da teoria da decisão de forma prática para abordar decisões que envolvem grande quantidade de incertezas e complexas compensações de preferências (HOWARD e MATHESON, 1984; KEENEY e RAIFFA, 1976; VON WINTERFELDT; EDWARDS e BARRON, 1986). A teoria da decisão está arraigada nos axiomas da teoria da probabilidade (BRADSTTAW e BOOSE, 1990) e da teoria da utilidade (VON NEUMANN e MORGENSTERN, 1953). A teoria da probabilidade define aquilo em que um decisor deve acreditar com base na evidência; a teoria da utilidade descreve o desejo do tomador de decisões e a teoria da decisão reúne as duas para sugerir o que o decisor deve fazer (RUSSELL e NORVIG, 2003). Baseado nesta teoria, o responsável pela decisão pode decidir de forma racional, apoiado nas preferências e desejos em contextos nos quais a incerteza e os objetivos conflitantes o deixam a decisão mais complexa. 
Alguns métodos se destacam como ferramentas de análise multicritério. Entre eles estão os métodos ELECTRE e PROMETHEE (GOMES; et al., 2004). Os métodos da família ELECTRE são chamados de métodos de sobreclassificação, que procuram eliminar alternativas dominadas devido aos pesos julgados pelo decisor (MOTA, 2005). Já o método PROMETHEE se destaca por utilizar as informações intercritério (importância entre os critérios) e intracritério (importância das alternativas dentro de cada critério). Já os métodos nos quais a teoria da utilidade multiatributo acha-se inserida, alicerçam-se na definição de uma função que designa um valor a cada alternativa, resultado de sua avaliação segundo cada critério. Tais métodos pressupõem ainda que não existe a incomparabilidade e que existe transitividade nas relações de preferências e de indiferença entre as alternativas (KEENEY e RAIFFA, 1976). Destacam-se a própria teoria da utilidade multiatributo, introduzida por Keeney e Raiffa (1976) e simplificada pelos métodos associados à ferramenta Simple MultiAttribute Ranking Technique (SMART), SMARTS e SMARTER (EDWARDS e BARRON, 1994), o AHP, que faz uso da construção de uma hierarquia de critérios, introduzido por Saaty (1980) e o método ANP (GOMES et al., 2004).

Esta pesquisa utiliza o método SMART como ferramenta para a tomada de decisão multicritério. Neste método, as funções de utilidade são capazes de incorporar as tolerâncias ao risco dos decisores envolvidos, para avaliar as consequências de um conjunto de alternativas (KEENEY e WINTERFELDT, 2009). Esse processo permite criar uma nova escala denominada de "escala de utilidade". O processo de escolha é então realizado com base na nova escala que agrega os aspectos de incerteza e preferência inerente ao problema de decisão (GOMES et al., 2002). A tomada de decisão, na maioria das vezes, é de nível estratégico, como nesta pesquisa, e envolve a consideração de mais de um critério. Problemas como esses, em que os resultados são caracterizados por dois ou mais critérios num mesmo problema, muitos destes conflitantes, são manipulados pela teoria da utilidade multiatributos (Multiple Attribute Utility Theory - MAUT). O conceito essencial dessa teoria é o da compensação, em que o decisor deve encontrar uma função de utilidade multiatributo para cada um dos diferentes atributos ou critérios (MOTA, 2005). Dessa forma, curvas de utilidade para cada critério geralmente são obtidas para representar a conduta com relação ao risco dos decisores. Segundo Ensslin et al. (2001), as funções de utilidade são aplicadas para transformar os valores quantitativos e qualitativos associados aos critérios de cada alternativa em uma escala de dimensão comum, com o obejtivo de se ter uma função de utilidade global, dada para cada alternativa. Isso é possível por meio da adição das utilidades dos critérios envolvidos. Esta função consiste, simplesmente, em uma média ponderada das utilidades 
individuais (GOMES et al., 2002; KEENEYe RAIFFA, 1976), levando em consideração cada alternativa. Assim, tem-se.

Seja $a(a=1,2, \ldots, A)$ o índice que identifica as alternativas e $i(i=1,2, \ldots, I)$ o índice que identifica os critérios, então a função de utilidade aditiva tem a forma:

$$
U(a)=\sum_{i=1}^{I} k_{i} u_{i}\left(x_{i}(a)\right)
$$

Onde, $U(a)$ é o valor global da função utilidade da alternativa $a ; x_{i}(a)$ é o desempenho da alternativa $a$ em relação ao critério $i$; $u_{i}($.$) é a função de utilidade parcial da$ alternativa $a$ em relação ao critério $i$; e finalmente $k_{i}$ é o peso do critério $i$, que se refere ao grau de relevância do critério com relação ao objetivo geral.

\subsubsection{Compensações de preferências na escolha das alternativas para o recolhimento do palhiço: uma análise multicritério}

Este tópico apresenta as alternativas de recolhimento do palhiço e os principais critérios que compõem a árvore de decisão multicritério. Os critérios e as alternativas são levantados a partir da literatura e validados pelos decisores das indústrias. As alternativas são os cursos alternativos de ação para atingir os objetivos propostos. São consideradas para a pesquisa as alternativas de colheita integral, colheita parcial e enfardamento.

Já os critérios se referem aos principais fatores que demonstram influenciar na decisão do tipo de colheita e transporte do palhiço no campo para a indústria. Segundo Pierossi e Fagundes (2013), os principais pontos a serem considerados na retirada do palhiço do campo são: custo de transporte, umidade do palhiço no momento do transporte, produtividade de energia gerada a partir do palhiço e o desempenho na remoção de terra e na separação da cana e do palhiço na instalação industrial.

Segundo Hassuani et al. (2005), a densidade de carga é impactada negativamente pelo aumento do teor de impureza vegetal, ou seja, folha, palhiço, ponteiros e raíz, representando um importante fator na composição de custos desta operação. A densidade da mistura cana picada e palhiço cai cerca de $1 / 3$ a $1 / 4$ quando se transporta cargas com 10 a $15 \%$ de impurezas vegetais. Outro aspecto que deve ser considerado é a umidade do teor de palhiço, a umidade aumenta o peso do palhiço no transporte além de dificultar a limpeza das impurezas no sistema de limpeza a seco. No sistema de colheita integral e parcial o palhiço possui umidade em torno de 35 a 40\%, enquanto que o palhiço enfardado a umidade é de aproximadamente $15 \%$, pois ele é realizado dias depois da colheita, exatamente para garantir 
a secagem do palhiço (PIEROSSI e FAGUNDES, 2013). Quanto às impurezas minerais, que constituem terras e sais minerais presentes no palhiço, elas também são fatores críticos no processo, por isso torna-se necessária a limpeza do palhiço para alcançar valores abaixo de $2 \%$ de impurezas minerais. Segundo levantamentos de campo efetuados por Ripoli (2004), o teor de impurezas minerais encontrado no palhiço enfardado é de 6,43\%.

Outro ponto a ser considerado é o desempenho da separação cana/palhiço. Na colheita integral e parcial esse fator é medido pela eficiência da estação de limpeza a seco, pois o custo deve ser calculado em função da quantidade de palhiço separado na unidade industrial e não em função da quantidade de palhiço transportado. Estações de limpeza com maiores eficiências fazem com que o custo total do palhiço seja menor quando comparado às unidades menos eficientes, além disso, as caldeiras trabalham de modo mais eficaz quando a quantidade de impurezas é mínima (GERMEK, 2005). Já em relação ao enfardamento, a eficiência de separação cana/palhiço depende do desempenho dos ventiladores da colhedora de cana, que ventilam o material mais leve (palhiço) para o solo ao colher a cana-de-açúcar (RIPOLI, 2004).

Prado (2007) também aponta como um aspecto relevante do processo da cogeração com o palhiço, a maior possibilidade de geração de material particulado para a atmosfera devido às impurezas presentes nessa biomassa o que significa maior custo de investimento para a caldeira e os equipamentos para remoção de material particulado como a estação de limpeza à seco (PIEROSSI e FAGUNDES, 2013). Este custo de investimento, quando comparado com novas usinas termelétricas e gás natural, que necessitam montar toda a unidade de geração, o setor sucroalcooleiro apresenta a vantagem de necessitar apenas de expansão do sistema de geração. Além disso, Redígolo (2014) destaca que é estimado um período de 24 meses para a construção de uma central de cogeração em uma usina sucroalcooleira, o que representa um curto período em relação à novas instalações para produção de energia. O investimento nesse setor também prevê menores riscos de imprevistos e problemas reduzidos durante a construção, além da disponibilidade de tecnologia nacional para a execução do projeto. Hassuani et al., (2005) afirmam que o investimento que deve ser feito pela usina é definido de acordo com a tecnologia a ser utilizada. Quando se considera o sistema de enfardamento para recolhimento do palhiço, deve-se investir em máquinas enfardadoras, trituradores e sistema de transporte para recolhimento dos fardos, enquanto que para a colheita integral e parcial, deve ser adquirido o sistema de limpeza à seco e uma frota adicional de caminhões para transportar o palhiço junto com a cana.

Cabe ressaltar os custos operacionais: custos anuais responsáveis pela operação e 
manutenção dos insumos e maquinários. Dentre eles se destacam os custos com transporte, mão-de-obra, consumo de energia e custos de manutenção dos equipamentos agrícolas e industriais para a cogeração. Para Smithers (2014), a grande dificuldade para o aproveitamento do palhiço é o custo gerado ao sistema de transporte, no que diz respeito principalmente aos gastos com combustível. O consumo de energia também deve ser considerado, visto que, para Ripoli (2004), os sistemas de colheita integral e parcial que utilizam a estação de limpeza e pré-tratamento das impurezas consome muita energia com o acionamento de motores elétricos, mas economiza em diesel por fazer a colheita do palhiço juntamente com a cana. Já em relação aos custos com mão-de-obra, eles são maiores para o enfardamento, pois duas colheitas são necessárias, sendo empregada muita mão-de-obra nas operações de transporte em geral e carregamento e descarregamento dos fardos. Referente aos custos de manutenção, para a atividade de recolhimento de palhiço é necessária a mobilização de um intenso maquinário que acarreta altos custos de manutenção. Para a colheita integral e parcial esses custos são relativamente estão relacionados principalmente aos veículos de colheita e transbordo e à estação de limpeza a seco. Já para o enfardamento, os custos de manutenção de equipamentos estão ligados sobretudo à manutenção da enfardadora, da enleiradora, da carreta recolhedora e de toda a frota de veículos dedicados ao transporte de fardos (MICHELAZZO e BRAUNBECK, 2008).

Além dos custos de investimentos e operacionais, a receita da comercialização de energia a partir do palhiço também é um critério importante a ser considerado nesta tomada de decisão, pois esse valor depende do preço da energia e da produtividade de energia gerada por tonelada de palhiço, que está intimamente ligada às alternativas de recolhimento de palhiço. Segundo Souza e Azevedo (2006), definir o valor esperado da receita é essencial para as decisões de cogeração de energia, visto que o preço da energia está incluso neste cálculo e é um fator crítico para as usinas por ser muito volátil. Este fato pode ser ilustrado por um estudo realizado por Furlan et al. (2013). Ao comparar três cenários diferentes, uma biorrefinaria flexível (capaz de alternar a produção de etanol de segunda geração e eletricidade), uma usina que gera etanol de primeira e segunda geração e uma usina que produz etanol e energia, eles notaram que a receita apresentada depende fundamentalmente do cenário econômico (preço da energia) e da produtividade do processo.

\subsection{2 Árvore de decisão baseada em valor e probabilidades}


Árvores de decisão são conhecidas por auxiliar os gestores no processo de decisão quando existem possibilidades variadas de curso de ação, como no caso de variação do preço de energia que será avaliado nesta dissertação. A árvore de decisão baseada em valor e probabilidades proveem uma estrutura efetiva na qual é possível identificar opções e investigar os possíveis resultados de escolher alguma dessas opções (QUINLAN, 1989). Silva et al. (2008) ressaltam que o método de árvore de decisão utiliza informações que se referem às probabilidades de determinado evento ocorrer. Para isto, o método incorpora aspectos de risco e incerteza na análise de alternativas, a medida que o preço da energia varia substanciamente. Essa característica faz com que o método de árvore de decisão seja considerado superior aos métodos tradicionais, pois tende a conduzir a escolhas certas por propiciar melhores condições ao tomador de decisões de visualizar os riscos (CASAROTTO FILHO, KOPITTKE, 2010). No caso desta dissertação, a árvore irá auxiliar o decisor na avaliação do valor esperado da receita tendo em vista as alternativas de recolhimento do palhiço.

Segundo Galesne et al. (1999), são necessárias três etapas para a elaboração da árvore de decisão: (i) previsão de todas as consequências possíveis que cada decisão fundamental pode trazer; (ii) atribuição de probabilidades às diferentes consequências decorridas das decisões iniciais e; (iii) avaliação das alternativas em direção a uma solução ótima.

Deste modo, o primeiro passo para a construção da árvore consiste em considerar todas as alternativas importantes, pois um erro recorrente entre os manipuladores da árvore de decisão é ignorar estas alternativas e chegar a conclusões errôneas. Sendo assim, somente quando todas as alternativas de decisão forem exploradas, a organização poderá maximizar o resultado favorável almejado (CASAROTTO FILHO, KOPITTKE, 2000). De acordo com Kliemann Neto (2010), os nós de decisão na árvore de valor representam as decisões a ser tomadas pelo decisor e são geralmente identificados por um quadrado, no modelo desta dissertação este nós são representados pelas opções de recolhimento do palhiço.

Em seguida, é necessário eliciar a previsão dos acontecimentos incertos possíveis de cada decisão. Segundo Azevedo et al. (2013) os nós de incerteza são identificados por um círculo e são apresentados na árvore de decisão como o preço da energia no mercado.

Os ramos que resultam do nó de decisão representam os possíveis resultados de um determinado curso de ação e o ramo seguinte será determinado, não pelo tomador de decisão, mas por circunstâncias que estão além do controle dele. Os ramos que emanam de um círculo são, portanto, rotulados com probabilidades que representam a estimativa sobre a probabilidade de que um ramo específico seja seguido. Dessa forma, a segunda etapa para 
construção da árvore está relacionada à atribuição de probabilidades aos preços da energia no mercado.

Por fim, a última condição para a aplicação da árvore refere-se à avaliação dos resultados relacionados às alternativas existentes. 


\section{METODOLOGIA}

Neste capítulo discutem-se os modelos e informações utilizadas para alcançar os objetivos propostos no estudo.

Para se alcançar o objetivo geral de desenvolvimento de um modelo genérico para as decisões de recolhimento de palhiço de cana-de-açúcar, esta dissertação procura primeiramente definir os critérios relevantes para as alternativas de recolhimento de palhiço. De posse dos dados e informações obtidos é possível elaborar o modelo genérico baseado em uma estrutura hierárquica de objetivos para o recolhimento do palhiço. Porém um dos objetivos desta estrutura, valor esperado da receita, varia conforme o preço da energia no mercado. Portanto, uma análise baseada no valor esperado da receita considerando as alternativas de recolhimento de palhiço é feita usando árvore de valor e probabilidades. Posteriomente, o valor esperado da receita constitui, juntamente com os demais objetivos, a estrutura hierárquica de objetivos. Nesta dissertação, os dados são baseados em usinas sucroalcooleiras que moem aproximadamente 3 milhões de toneladas de cana por safra.

\subsection{Escolha da abordagem multicritério}

Devido aos desafios econômicos e das operações de recolhimento do palhiço e comercialização da energia gerada a partir dessa biomassa, muitos critérios devem ser considerados (RIPOLI, 2004), e alguns métodos na literatura podem ser escolhidos tendo em vista esses critérios. Segundo Gomes et al., (2004) escolher um método multicritério envolve vários fatores como as características do problema, do contexto considerado, e da estrutura de preferências do decisor. Por outro lado, estudos comparativos entre os diferentes métodos de apoio à decisão multicritério mostram que não existem metodologias que podem ser apontadas como melhores em relação às outras em qualquer situação (FIGUEIRA et al., 2005), e assim os métodos de apoio à decisão podem representar diferentes respostas para o mesmo problema (OZERNOY, 1992). Segundo Ozernoy (1992), a escolha de um método não adequado pode resultar na sugestão de uma alternativa que possa não ser justificada. Por isso é importante identificar qual método é mais adequado, considerando paralelamente o contexto e o tipo de problema tratado.

Opta-se então pelo uso de métodos analíticos da escola americana. Como definido por Gomes et al., (2002), estes algoritmos não permitem incomparabilidades entre as alternativas (o decisor deve ser capaz de escolher) e garantem a existência de transitividade. A escolha 
pela ferramenta SMART se deve também às suas principais aplicações serem referentes à assuntos ligados ao meio ambiente, transporte, logística em geral e problemas de manuseio de carga (VELASQUEZ e HESTER, 2013); ou seja, temas que envolvem esta pesquisa. Aguezzoul (2014) realizou uma revisão de literatura sobre critérios e métodos para problemas logísticos por meio de artigos publicados entre 1994 e 2013 em importantes bases de dados. Foram categorizados cinco grupos, os quais foram chamados: abordagem Multi Criteria Decision Making (MCDM), abordagem estatística, inteligência artificial, programação matemática e os métodos combinados ou híbridos. Os autores tiveram como resultados que as abordagens MCDM são amplamente utilizadas para os problemas logísticos (82\% dos casos).

A técnica Simple Multi-atribute Rating Technique (SMART) foi divulgada por Edwards em 1971 e é uma das ferramentas da abordagem Multi Criteria Descision Making (MCDM) (GOODWIN e WRIGHT, 2005). Outro fator que contribui para a escolha da ferramenta SMART para esse estudo é o fato que os tomadores de decisão sem auxílio de um método estruturado tendem a comprometer alguns objetivos em caso de problemas de decisão que envolvem uma série de objetivos, como no caso desta pesquisa. Isso pode levar à seleção de opções que funcionam bem em apenas um objetivo, ou a rejeição de opções relativamente atraentes porque seu bom desempenho em vários objetivos não é permitido para compensar o mau desempenho em outros. Dessa forma, o SMART é utilizado quando o decisor é confrontado com um problema relativamente complexo, com muita informação para lidar simultaneamente, para que o tomador de decisão seja forçado a usar estratégias mentais simplificadas, ou heurísticas, para chegar a uma escolha. Essa razão, juntamente com a velocidade relativa com que o método pode ser aplicado, além do fato da simplicidade tanto das respostas necessárias do decisor e a maneira em que estas respostas são analisadas, favorece o uso do SMART como ferramenta para esta pesquisa.

\subsection{Estrutura hierárquica de objetivos}

A abordagem multicritério é utilizada para a determinação da melhor alternativa de recolhimento de palhiço a partir de critérios quantitativos e qualitativos. O Quadro 4 apresenta as etapas e os respectivos objetivos e métodos utilizados nesta pesquisa. 
Quadro 4: Etapas da análise multicritério

\begin{tabular}{|c|c|c|c|}
\hline & Etapas & Objetivo & Métodos \\
\hline 1 & $\begin{array}{l}\text { Entendimento do } \\
\text { problema }\end{array}$ & $\begin{array}{c}\text { Alinhamento sobre a } \\
\text { percepção dos decisores em } \\
\text { relação ao problema a ser } \\
\text { resolvido }\end{array}$ & $\begin{array}{c}\text { Entrevista com decisores estratégicos } \\
\text { envolvidos no problema }\end{array}$ \\
\hline 2 & Definição dos critérios & $\begin{array}{l}\text { Construção da estrutura } \\
\text { hierárquica de objetivos e } \\
\text { definição dos critérios para } \\
\text { mensuração dos objetivos }\end{array}$ & $\begin{array}{l}\text { Apoio na literatura, bem como entrevista } \\
\text { e visitas para determinar os fatores } \\
\text { relevantes (Keeney e Winterfeldt, 2009) }\end{array}$ \\
\hline 3 & $\begin{array}{l}\text { Definição das } \\
\text { alternativas }\end{array}$ & Geração das alternativas & $\begin{array}{c}\text { Revisão da literatura, entrevistas e } \\
\text { visitas }\end{array}$ \\
\hline 4 & $\begin{array}{l}\text { Avaliação das } \\
\text { alternativas para cada } \\
\text { critério }\end{array}$ & $\begin{array}{l}\text { Elaboração das curvas de } \\
\text { utilidade para cada critério }\end{array}$ & $\begin{array}{l}\text { Método do equivalente certo para a } \\
\text { determinação das curvas de utilidade dos } \\
\text { critérios (Goodwin e Wright, 2004). } \\
\text { Para o critério “valor esperado da } \\
\text { receita” é utilizada a árvore de valor e } \\
\text { probabilidades (Goodwin e Wright, } \\
\text { 2004). }\end{array}$ \\
\hline 5 & $\begin{array}{l}\text { Hierarquização dos } \\
\text { critérios }\end{array}$ & $\begin{array}{l}\text { Preferências do decisor em } \\
\text { relação ao conjunto de } \\
\text { critérios }\end{array}$ & $\begin{array}{c}\text { Método SMART para determinação da } \\
\text { hierarquia dos critérios (Goodwin e } \\
\text { Wright, 2004). }\end{array}$ \\
\hline 6 & $\begin{array}{l}\text { Avaliação das } \\
\text { alternativas }\end{array}$ & $\begin{array}{l}\text { Valor da utilidade de cada } \\
\text { alternativa e o valor global }\end{array}$ & $\begin{array}{l}\text { Aplicação do modelo de utilidade global } \\
\text { em função de pesos definidos e as } \\
\text { funções de utilidade de cada critério } \\
\text { (Loken, Botterud e Holen, 2009) }\end{array}$ \\
\hline 7 & $\begin{array}{c}\text { Análise de } \\
\text { sensibilidade }\end{array}$ & $\begin{array}{l}\text { Verificação da aderência da } \\
\text { solução obtida. }\end{array}$ & $\begin{array}{c}\text { Variação nos pesos dos critérios gerais; } \\
\text { utilização da ferramenta ROC para } \\
\text { hierarquização dos critérios; Análise de } \\
\text { Monte Carlo para variação do preço da } \\
\text { energia. }\end{array}$ \\
\hline 8 & $\begin{array}{c}\text { Definição da } \\
\text { alternativa com } \\
\text { melhor desempenho }\end{array}$ & $\begin{array}{l}\text { Geração da melhor } \\
\text { alternativa }\end{array}$ & $\begin{array}{c}\text { Definição da alternativa pelo software } \\
\text { utilizado }\end{array}$ \\
\hline
\end{tabular}


As etapas e métodos apresentados no Quadro 4 são explicados detalhadamente nos próximos itens.

\section{Entendimento do problema, definição dos critérios e das alternativas}

As etapas de 1, 2 e 3, de construção do modelo genérico, ou seja, o entendimento do problema, identificação dos critérios e alternativas são realizadas a partir da literatura, participação em eventos do tema e confirmados por meio das visitas às usinas. Nestas etapas, os entrevistados são questionados individualmente por meio de entrevistas semiestruturadas que auxiliam no entendimento de assuntos gerais relacionados ao recolhimento de palhiço e cogeração de energia. Na visão de Gil (2002), a entrevista semiestruturada é guiada por relação de pontos de interesse que o entrevistador vai explorando ao longo de seu curso. As entrevistas são realizadas com indivíduos da organização que conhecem profundamente a rotina organizacional e validada com opiniões de outros funcionários das usinas. $\mathrm{O}$ roteiro da entrevista semiestruturada (Apêndice A) aborda primeiramente uma caracterização do respondente e em seguida assuntos gerais ligados aos temas de recolhimento e cogeração de energia a partir do palhiço:

- Caracterização do entrevistado

- Detalhamento sobre o sistema de recolhimento de palhiço e cogeração de energia, funcionamento, investimentos;

- Principais fatores considerados para a decisão de recolhimento de palhiço;

- Custos determinantes para a viabilidade dos projetos de recolhimento de palhiço e cogeração com o palhiço;

- Custos operacionais relevantes para o recolhimento de palhiço;

- Principais dificuldades enfrentadas pelas usinas para a cogeração com o palhiço;

- Comercialização dos excedentes de energia;

- Fatores que interferem na decisão de produzir e vender energia;

- Estoque de palhiço.

Nesta etapa, após as visitas às usinas, participação em eventos e pesquisa de literatura, é possível delinear o problema e identificar os principais trade offs entre cada critério e as alternativas de recolhimento de palhiço. 
$\mathrm{Na}$ etapa 4 os critérios podem ser classificados como qualitativos ou quantitativos (GOODWIN e WRIGHT , 2004). Os critérios qualitativos referem-se àqueles que estão dotados sempre de alguma subjetividade. Estes critérios podem ser quantificáveis por meio de um esforço para encontrar atributos quantificáveis relacionados ao critério. $\mathrm{O}$ atributo "qualidade do palhiço", por exemplo, pode ser quantificável por meio do teor de impurezas do palhiço. Depois desta quantificação dos critérios, curvas de utilidade para cada critério são obtidas para representar a conduta com relação ao risco dos decisores. Segundo Ensslin et al. (2001), as funções de utilidade são aplicadas para transformar os valores (quantitativos e qualitativos) associados aos critérios de cada alternativa em uma escala de dimensão comum. Assim, a função de utilidade deve representar a preferência dos decisores. Sua obtenção é realizada por meio do método do "equivalente certo" que exige do decisor a pensar em termos de apostas (SANAYEI et al., 2008; GOODWIN e WRIGHT, 2005; LOKEN et al., 2009). Este método é sintetizado na Figura 8 por meio de um fluxograma e ilustrado no Apêndice B.

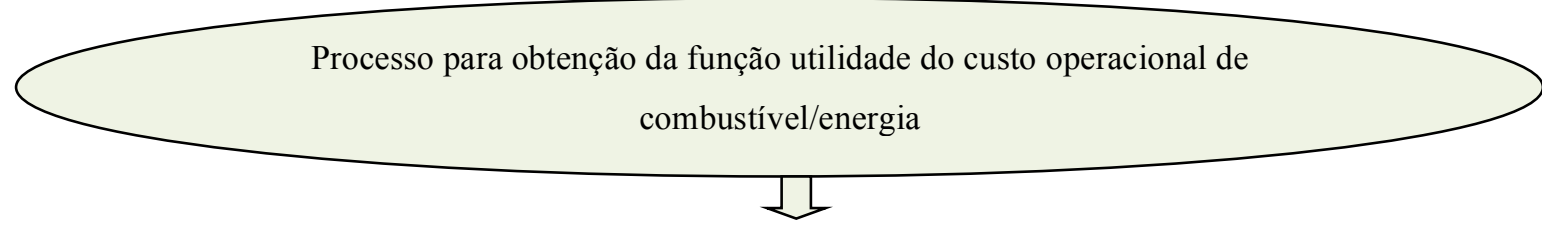

Analista: Dado os custos anuais de combustível e energia. Supor que um planejamento ótimo implique em $50 \%$ desse valor (lim. Inf.) e uma péssima alternativa provoque um aumento de $50 \%$

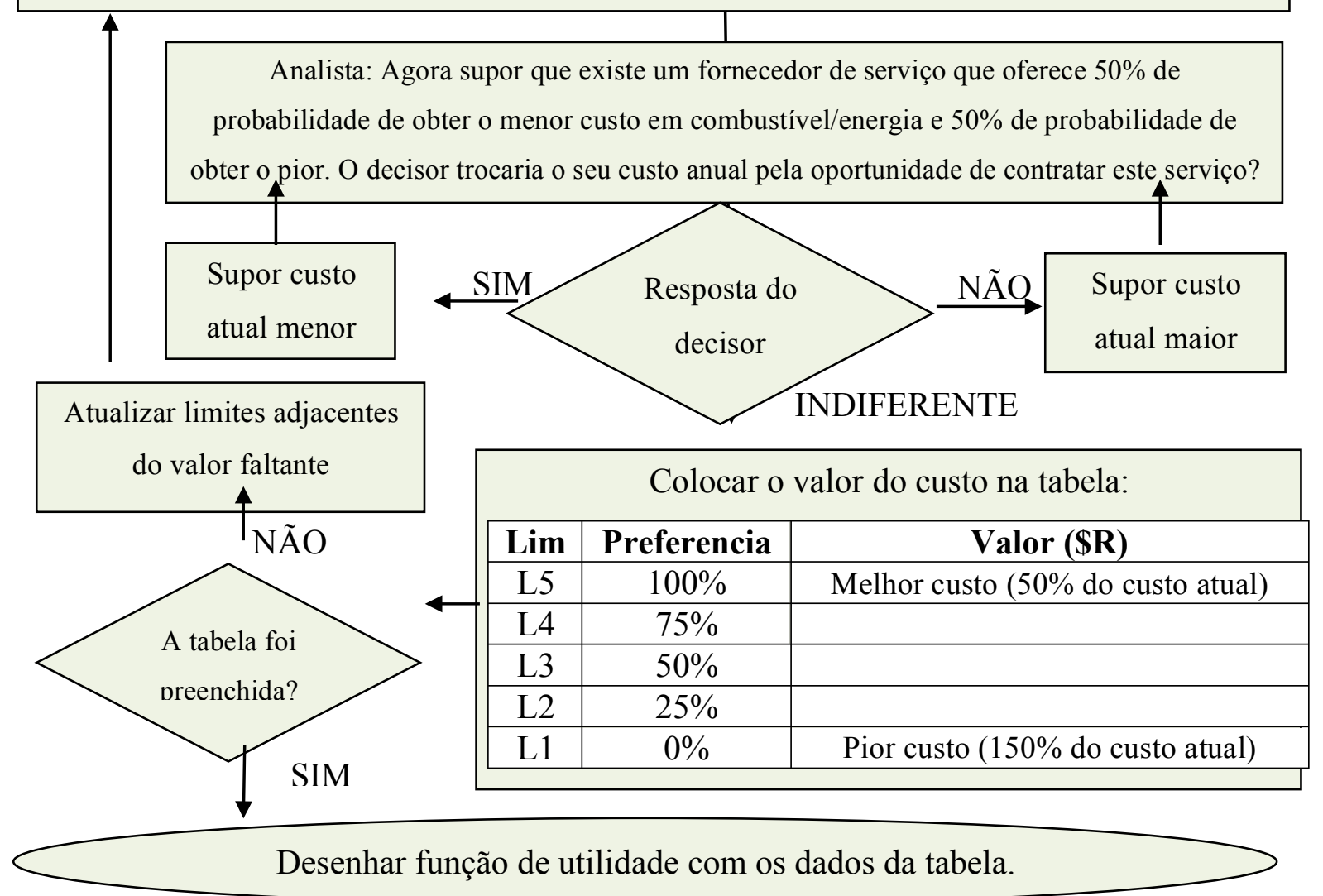

Figura 8: : Fluxograma para obtenção das curvas de utilidade 
A Figura 8 mostra as etapas para a construção da curva de utilidade para o critério "custo operacional de combustível/energia". Para isso, o analista supõe uma loteria em que o decisor tem $50 \%$ de chance de ter um custo operacional de combustível/energia ótimo (50\% do custo atual) e $50 \%$ de probabilidade de ter o pior custo ( $150 \%$ do custo atual). Se o decisor responder que trocaria o seu custo atual pela oportunidade de apostar nessa loteria, o analista supõe um custo atual menor. Se o respondente não trocar seu custo atual para jogar nessa loteria, o analista supõe um custo maior. Essas suposições devem ocorrer até o momento em que o analista for indiferente em jogar na loteria. Neste ponto, esse custo atual deve ser utilizado para estabelecer os limites superior e inferior da curva de utilidade, sendo o limite superior, ou seja, de utilidade 100, representado pelo menor custo (50\% do custo atual estabelecido), e o limite inferior, de utilidade 0 , representado pelo pior custo ( $150 \%$ do custo atual estabelecido). Feito isso, os dados com suas unidades reais coletados nas usinas são transformados em utilidades de acordo com a função utilidade de cada critério

Diferente dos outros critérios, para o critério "valor esperado da receita" é elaborada uma árvore de valor a fim de analisar a receita da comercialização do excedente de energia com o palhiço de cana considerando as alternativas de recolhimento do palhiço e os preços da energia no mercado. Assim, por meio do valor esperado da receita de cada alternativa de recolhimento, é então possível atribuir utilidades para esses valores. A árvore de valor, no entanto, carece de um aspecto importante para a tomada de decisão: a incorporação dos riscos e das incertezas associadas aos investimentos. Essas incertezas são inseridas no modelo a partir das probabilidades de ocorrência dos preços da energia.

Para a construção da árvore, é necessária a definição dos nós de incerteza do modelo e suas probabilidades, que neste caso se referem aos preços que a energia elétrica pode alcançar no período de análise e às probabilidades de ocorrência destes preços. Para que sejam estimadas as probabilidades de ocorrência em cada ramo da árvore de decisão, esta etapa considera a realização prévia de uma pesquisa no histórico de preços de energia no mercado spot. Estes preços são fornecidos pela Câmara de Comercialização de Energia Elétrica (CCEE) que realiza mensalmente o cálculo da média mensal do Preço de Liquidação das Diferenças (PLD). Esta pesquisa considera o período de 4 anos (2014 a 2017) da região Sudeste/Centro-oeste por nela estar situada a maioria das usinas sucroalcooleiras do país. O Quadro 5 apresenta o PLD mensal para este período. 
Quadro 5: PLD médio (R\$) no período de jul./2016 a jun./2017 nas regiões SE e CO. Fonte: CCEE

\begin{tabular}{ccccc}
\hline Meses/ Ano & $\mathbf{2 0 1 4}$ & $\mathbf{2 0 1 5}$ & $\mathbf{2 0 1 6}$ & $\mathbf{2 0 1 7}$ \\
\hline Janeiro & 378 & 388 & 35 & 121 \\
Fevereiro & 822 & 388 & 30 & 128 \\
Março & 822 & 388 & 37 & 216 \\
Abril & 822 & 388 & 49 & 371 \\
Maio & 806 & 387 & 75 & 411 \\
Junho & 412 & 372 & 61 & 124 \\
Julho & 592 & 240 & 83 & 280 \\
Agosto & 709 & 145 & 115 & 505 \\
Setembro & 728 & 227 & 149 & 521 \\
Outubro & 776 & 212 & 200 & 533 \\
Novembro & 804 & 202 & 166 & 425 \\
Dezembro & 601 & 116 & 122 & 235 \\
\hline
\end{tabular}

Alguns parâmetros em relação a esse conjunto de números são apresentados no Quadro 6 a fim de dividir esses dados em classes e intervalos para então, ser possível estimar a probabilidade de ocorrência dos preços da energia.

Quadro 6: Parâmetros referentes aos dados do PLD de 2014 a 2017

\begin{tabular}{cc}
\hline Amplitude & 792,0 \\
\hline Raiz quadrada da quantidade de dados & 6,9 \\
Primeira estimativa para classe & 114,3 \\
Intervalo definido & 100,0 \\
\hline
\end{tabular}

Definido o número de classes e seus intervalos, o Quadro 7 apresenta os limites inferiores e superiores de cada classe, o ponto médio de cada classe, o número de ocorrências e a frequência do PLD entre esses limites. Esses dados são estabelecidos para se levantar um histograma para avaliação do comportamento do preço da energia em 4 anos. Assim, trabalhase com os preços médios da energia, agrupados em classes de frequência, e as respectivas probabilidades de ocorrência. 
Quadro 7: Características referente aos dados do PLD de 2014 a 2017

\begin{tabular}{cccccc}
\hline Classes & Limite inferior & Limite superior & Ponto médio & Ocorrências & Frequência \\
\hline 1 & 0 & 100 & 50 & 7 & $14,6 \%$ \\
2 & 100 & 200 & 150 & 10 & $20,8 \%$ \\
3 & 200 & 300 & 250 & 7 & $14,6 \%$ \\
4 & 300 & 400 & 350 & 8 & $16,7 \%$ \\
5 & 400 & 500 & 450 & 3 & $6,3 \%$ \\
6 & 500 & 600 & 550 & 4 & $8,3 \%$ \\
7 & 600 & 700 & 650 & 1 & $2,1 \%$ \\
8 & 700 & 800 & 750 & 3 & $6,3 \%$ \\
9 & 800 & 900 & 850 & 5 & $10,4 \%$ \\
\hline
\end{tabular}

Dessa forma, o modelo se estrutura em 9 faixas de preços de energia e considera o valor do ponto médio de cada classe. Para estimar as probabilidades é utilizada a frequência de ocorrência dos preços da energia dessas classes. Assim, a árvore baseada em valor e probabilidades para se definir o valor esperado da receita de cada alternativa de recolhimento de palhiço apresenta a estrutura da Figura 9: 


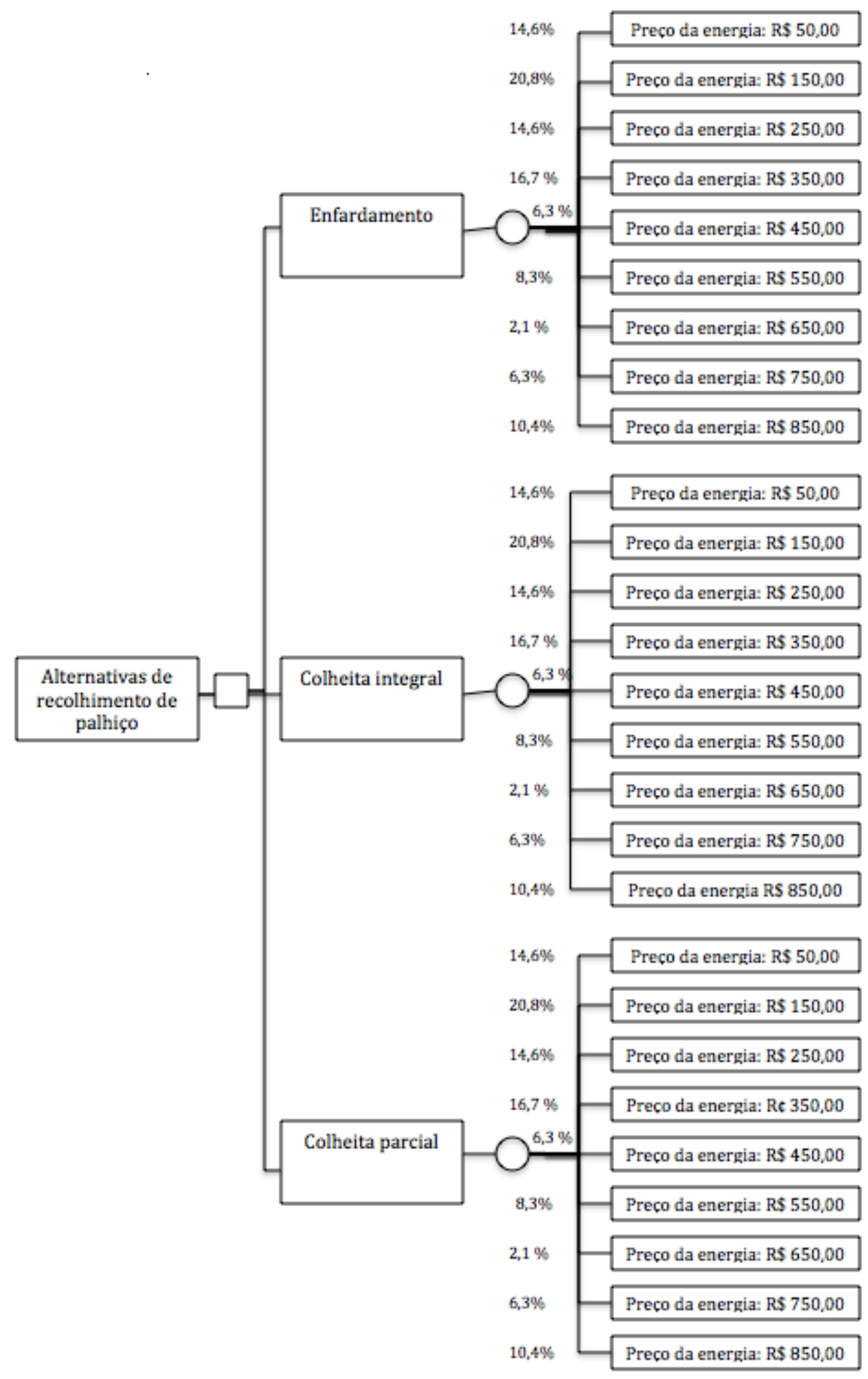

Figura 9: Estrutura da árvore de valor e probabilidades 
É então calculado o valor esperado da receita por meio da multiplicação da receita de cada ramo por sua respectiva probabilidade. Ao final do processo é possível obter o Valor esperado de cada alternativa de recolhimento de palhiço que representará o critério "valor esperado da receita" na estrutura hierárquica de objetivos', para então definir suas utilidades.

\section{Hierarquização dos critérios}

A etapa 5 consiste na definição das ponderações ou pesos para os critérios reflete a importância desses para o decisor no problema a ser solucionado. Assim, a atribuição de ponderações indica as preferências do decisor em relação ao conjunto de critérios. Muitos métodos estão disponíveis para ponderação de critérios e é extremamente importante conhecer as técnicas de atribuições de ponderações de pesos para escolher a mais adequada ao contexto. Segundo GOMES et al. (2002) os seis principais métodos de atribuição de pesos aos critérios são: Trade-off Weighting, Direct Rating, Método SMART, Swing Weighting, Rank Centroid (ROC) e AHP. Estes métodos são detalhados no Apêndice C, e os métodos utilizados nesta dissertação são apresentados na sequência. Nesta pesquisa são utilizados os métodos SMART e ROC, no entanto o método ROC é utilizado somente na fase de análise de sensibilidade.

O método SMART foi escolhido como ferramenta de ponderação devido ao seu amplo uso na literatura e simplicidade que se exige nas respostas do decisor, bem como pela maneira que estas respostas são analisadas. Neste método, os critérios são ordenados de forma decrescente sendo atribuído o valor 10 para o critério considerado menos importante. Os critérios restantes são avaliados em relação a este critério e os valores atribuídos devem ser maiores do que 10 e proporcionais à preferência. Depois, os pesos são calculados a partir da normalização da pontuação em relação ao total de pontos atribuídos (GOODWIN e WRIGHT, 2005). O Quadro 8 exemplifica a técnica.

Quadro 8: Atribuição de pesos com o método SMART. Fonte: Goodwin e Wright, 2005

\begin{tabular}{lcc}
\hline Critério A (mais importante) & 100 & $100 / 235=0,425532$ \\
Critério B & 70 & $70 / 235=0297872$ \\
Critério C & 30 & $30 / 235=0,127660$ \\
Critério D & 25 & $25 / 235=0,106383$ \\
Critério E (menos importante) & 10 & $10 / 235=0,04255$ \\
Somatório & 235 & \\
\hline
\end{tabular}


Desta forma, como resultado desta etapa é obtida uma hierarquia ou ordenação de critérios, indicando o grau em que cada um é importante com relação ao problema.

Para análise de sensibilidade utilizou-se a ferramenta ROC. Nesta técnica, os pesos são obtidos diretamente a partir da ordem de importância dos atributos e através de valores prédefinidos, chamados pesos ROC (BARRON E BARRET, 1996). A ideia chave é simples: se nada fosse sabido sobre os pesos, exceto sua soma, definida como 1 por convenção, então o conjunto das possíveis ponderações, não negativas, seria qualquer um que tivesse essa soma. O cálculo dos pesos ROC tem uma forma computacional conveniente, dado pela Equação (1):

$$
w_{k}=(1 / K) \sum_{i=k}^{K}\left(\frac{1}{i}\right)
$$

Onde $w_{k}$ é o valor peso ROC dos critérios de ordem $k$ e sabe-se que $w_{1} \geq w_{2} \geq \cdots \geq$ $w_{K},\left(w_{1}\right.$ é o atributo mais preferido e $w_{K}$ o menos preferido), então:

$$
\begin{gathered}
w_{1}=(1+1 / 2+1 / 3+\cdots+1 / K) / K \\
w_{2}=(0+1 / 2+1 / 3+\cdots+1 / K) / K \\
w_{3}=(0+0+1 / 3+\cdots+1 / K) / K \\
\vdots \\
w_{K}=(0+0+0+\cdots+1 / K) / K
\end{gathered}
$$

Os valores $w_{k}$ são sempre os mesmos para qualquer conjunto diferente de critérios. $\mathrm{O}$ Quadro 9 apresenta esses valores calculados quando se trabalha de 2 até 8 critérios.

Quadro 9: Pesos ROC de acordo com o número de atributos. Fonte: Edwards e Barron (1994)

\begin{tabular}{cccccccc}
\hline & \multicolumn{8}{c}{ Número de critérios } \\
Designação & $\mathbf{8}$ & $\mathbf{7}$ & $\mathbf{6}$ & $\mathbf{5}$ & $\mathbf{4}$ & $\mathbf{3}$ & $\mathbf{2}$ \\
\hline$w_{1}$ & 0,3397 & 0,3704 & 0,4083 & 0,4567 & 0,5208 & 0,6111 & 0,7500 \\
$w_{2}$ & 0,2147 & 0,2276 & 0,2417 & 0,2567 & 0,2708 & 0,2778 & 0,2500 \\
$w_{3}$ & 0,1522 & 0,1561 & 0,1583 & 0,1567 & 0,1458 & 0,1111 & \\
$w_{4}$ & 0,1106 & 0,1085 & 0,1085 & 0,0900 & 0,0625 & & \\
$w_{5}$ & 0,0793 & 0,0728 & 0,0611 & 0,0400 & & & \\
$w_{6}$ & 0,0543 & 0,0442 & 0,0278 & & & & \\
$w_{7}$ & 0,0335 & 0,0204 & & & & & \\
$w_{8}$ & 0,0156 & & & & & & \\
\hline
\end{tabular}


Por meio das funções de utilidade e as ponderações definidas pelo decisor para cada critério é possível obter um valor de utilidade global para cada alternativa (Etapa 6). Este valor fundamenta-se na função de utilidade multicritério (apresentada na seção 2.4), e definida na forma aditiva pela Equação (2) por Loken et al., (2009).

$$
U(a)=\sum_{i=1}^{I} k_{i} u_{i}\left(x_{i}(a)\right)
$$

$\mathrm{Na}$ Equação 2, a representa a alternativa avaliada, $U(a)$ é o valor global da função utilidade da alternativa $a$; $i$ representa os critérios do problema; $x_{i}(a)$ é o desempenho da alternativa a em relação ao atributo do critério $i ; u_{i}($.$) é a função de utilidade parcial do$ critério $i$ e finalmente $k_{i}$ é a ponderação ou preferência do critério $i$, que se refere ao grau de importância relativa. A alternativa com maior valor nesta função pode ser então definida como solução provisória.

\section{Análise de sensibilidade}

Segundo Belton e Stewart (2002), a análise de sensibilidade (Etapa 7) permite verificar se as conclusões preliminares são suficientemente robustas, ou se são muito sensíveis a determinadas mudanças nas variáveis do modelo. Tais mudanças devem ser conduzidas para verificar o impacto de uma possível falta de informação ou, mesmo, até fornecer uma perspectiva diferente ao problema.

Dessa forma, são realizadas as seguintes análises de sensibilidade nesta pesquisa:

1) Variação na ponderação dos critérios gerais: Nesta análise é considerada a variação dos pesos dos critérios gerais. É feita a oscilação do peso desses critérios de tal forma que sua utilidade varie de 0 a 100 . Desta forma, é possível analisar as soluções do modelo frente às alterações nos pesos dos critérios.

2) Método Rank Centroid (ROC) para ponderação dos pesos dos critérios: A utilização da ferramenta Rank Centroid (ROC) é motivada para verificar se métodos mais simples para a ponderação dos critérios podem fornecer os mesmos resultados. Além disso, a mudança no método de ponderação dos critérios é útil no sentido de verificar quão confiável é a solução com melhor desempenho, ou se alguma pequena alteração nos pesos dos critérios podem exercer uma influência crítica na avaliação geral do modelo. 
3) Análise de Monte Carlo para variação no preço da energia elétrica: Dado que o preço da energia muda dinamicamente e influencia um dos critérios de maior peso (valor esperado da receita) dentro da estrutura hierárquica, a análise de Monte Carlo estabelece uma distribuição de probabilidade para a variável "preço da energia" e simula essa variável um número significativo de vezes para que a frequência relativa dos resultados sobre a alternativa de recolhimento de palhiço convirja para a probabilidade com confiabilidade desejada. O critério de simulação de Monte Carlo utiliza da técnica de amostragem aleatória, onde alguns parâmetros considerados mais sensíveis são tratados como variáveis aleatórias com distribuição de probabilidade estabelecida. A Lei dos Grandes Números assegura que a frequência relativa de ocorrência de um possível resultado $\mathrm{X}$ de uma variável aleatória converge para a probabilidade de ocorrência do resultado $\mathrm{X}$ à medida que é aumentado o número de repetições do experimento ao qual a variável aleatória está associada. Dessa forma, ao invés de trabalhar com poucos valores estimados para o preço da energia, trabalha-se com uma distribuição de probabilidades dos valores para esta variável e com base nas simulações pode-se simular muitos possíveis valores para o "valor esperado da receita" e então encontrar a alternativa de recolhimento de palhiço sugerida para cada uma dessas medidas.

\section{Determinar a alternativa recomendada}

Após todas estas fases, pode-se descobrir o quão bem cada alternativa se aproxima do objetivo global. No final desta etapa, a alternativa com melhor desempenho global é então definida (Etapa 8).

\subsection{Coleta e análise de dados}

Esta seção apresenta como foi realizada a coleta e análise dos dados, tendo como base 5 usinas do setor sucroalcooleiro, as quais foram escolhidas para a aplicação do modelo multicritério. Procurou-se trabalhar com um grupo de usinas com características similares entre si, representativas do setor, cujas características principais são apresentadas no Quadro 10. 
Quadro 10: Características das usinas estudadas

\begin{tabular}{cc}
\hline Perfil da empresa & Dados \\
\hline Receita & Aproximadamente 400 milhões de reais \\
Número de funcionários & Aproximadamente 3.000 funcionários \\
Quantidade de cana moída por safra & Superior a 3 milhões de toneladas \\
\hline
\end{tabular}

A coleta de dados para o entendimento do problema, definição dos critérios e alternativas do modelo foi realizada por meio de entrevistas semiestruturadas (Apêndice A) com gestores e operadores das áreas envolvidas no recolhimento de palhiço e cogeração de energia dessas 5 usinas. Ao longo das entrevistas, além das respostas dos decisores, foram realizadas observações diretas dos processos de cogeração de energia para uma melhor ambientação com o problema de pesquisa. Também foram obtidos arquivos como: relatórios, apresentações e arquivos internos das empresas. Estes documentos apresentam estudos e dados sobre o recolhimento de palhiço e, de uma forma mais ampla, sobre a cogeração de energia a partir dessa biomassa. Com base nessas informações foi possível delinear e definir o problema, bem como comprovar a necessidade de estudo sobre as alternativas de recolhimento do palhiço, devido ao grau de complexidade dessa decisão para as usinas.

Para o desenhos das curvas de utilidade (Apêndice B), ponderação de critérios (Apêndice D) e análises de sensibilidade, os dados foram coletados por meio de questionários e entrevistas aplicadas aos decisores estratégicos envolvidos no problema.

Os gestores das organizações que fizeram parte da pesquisa, seja por meio de entrevistas, reuniões e visitas técnicas e que ajudaram na definição do problema têm o seguinte perfil (Quadro 11).

Quadro 11: Perfil dos decisores

\begin{tabular}{cc}
\hline Perfil & Características \\
\hline Idade & Entre 35 e 50 anos \\
Cargo & Gerente industrial; Gerente operacional; Especialistas em geração de \\
energia; Coordenador industrial e operacional
\end{tabular}


Esses decisores acreditam que um modelo, composto por critérios bem definidos e considerando as alternativas usuais de recolhimento de palhiço com suas respectivas informações e dados para seu funcionamento, pode auxiliar as empresas para o melhor desempenho do sistema.

Todos os dados de saída das etapas são executados no software Visual Interactive Sensitivity Analysis (V.I.S.A.) proposto por Valerie Belton (Belton e Stewart, 2002). O V.I.S.A. é um programa computacional de apoio à decisão desenvolvido pela SIMUL8 (www.simul8.com/visa). Os critérios e alternativas representados na estrutura hierárquica de objetivos constituem dados de entrada no software, assim como os pesos e utilidades, que também são modelados a fim de encontrar uma solução viável para o problema. 


\section{RESULTADOS E DISCUSSÕES}

Esta seção objetiva apresentar o modelo genérico de tomada de decisão sobre as alternativas de recolhimento do palhiço com base nas etapas do Quadro 4, utilizando dados de usinas do setor sucroalcooleiro.

\subsection{Entendimento do problema}

Com capacidade de moagem de aproximadamente 3 milhões de toneladas de cana, as usinas típicas do setor sucroalcooleiro produzem açúcar, etanol, e energia. Essas usinas têm capacidade de geração em média de 200.000 a 300.000 MWh de energia por safra, e, geralmente, o consumo de energia elétrica é da ordem de $30 \mathrm{kWh} / \mathrm{t}$.cana, o que sugere um consumo de aproximadamente $90.000 \mathrm{MWh}$ por safra.

As usinas convencionais são autossuficientes em energia para seus processos e a comercialização do excedente é feita de acordo com as regras do mercado. Parte da energia pode ser vendida em um contrato regulado pelo governo, de longo prazo (20 anos) para concessionárias de energia, e outra parte pode ser vendida no mercado livre, onde a venda é feita com qualquer consumidor livre ou comercializadora ou até mesmo a liquidação fica livre no mercado de curto prazo na Câmara de comercialização de energia elétrica.

Essas usinas, em geral, produzem energia limpa e renovável a partir do bagaço e algumas delas também aproveitam a biomassa do palhiço para cogerar energia. No entanto, elas enxergam possibilidades de melhoria na eficiência energética devido principalmente à maior utilização do palhiço para cogeração e à geração de energia também no período de entressafra. Porém, a maior dificuldade apontada pelas usinas para a venda de excedentes de energia é a falta de previsibilidade do preço da energia para novos projetos, sendo este o fator mais importante para a decisão de utilizar o palhiço para a cogeração, pois, como o preço do recolhimento do palhiço é alto, o valor de venda de energia deve compensar esse gasto.

\subsection{Definição dos critérios}

Estes critérios são as variáveis relevantes para o problema, que quando agrupados de forma estruturada representam a estrutura hierárquica de objetivos do problema a ser resolvido. Segundo Keeney (1996) a decisão deve ser baseada no "pensamento de valor" e não no "pensamento das alternativas". O autor explica que no pensamento em "valor" é necessário 
que os decisores se questionem sobre os objetivos a serem buscados, para depois criar as alternativas que servirão para agregar tais valores. Os critérios são definidos a partir da revisão de literatura (seção 2.4) e são confirmados por meio dos questionamentos aos tomadores de decisão. Os critérios que compõem a estrutura hierárquica são definidos no Quadro 12. 
Quadro 12: Descrição dos critérios

\begin{tabular}{|c|c|c|}
\hline Critérios & $\begin{array}{l}\text { Indicadores } \\
\text { [unidades] }\end{array}$ & Descrição \\
\hline \multicolumn{3}{|l|}{ Custos de investimentos } \\
\hline Custo da enfardadora & Custo $[\mathrm{R} \$]$ & $\begin{array}{l}\text { Custo de aquisição da máquina que compacta o } \\
\text { palhiço em fardos. }\end{array}$ \\
\hline Custo da enleiradora & Custo $[\mathrm{R} \$]$ & $\begin{array}{l}\text { Custo de aquisição da máquina que agrupa o palhiço } \\
\text { em leiras. }\end{array}$ \\
\hline $\begin{array}{l}\text { Custo dos transportes de } \\
\text { fardos }\end{array}$ & Custo $[\mathrm{R} \$]$ & $\begin{array}{l}\text { Custo de aquisição dos carregamentos que transportam } \\
\text { os fardos até a usina. }\end{array}$ \\
\hline $\begin{array}{l}\text { Custo do sistema de } \\
\text { limpeza a seco }\end{array}$ & Custo [R\$] & $\begin{array}{l}\text { Custo de aquisição da estrutura e máquinas que fazem } \\
\text { a limpeza do palhiço e separação da cana. }\end{array}$ \\
\hline $\begin{array}{l}\text { Custo de outros } \\
\text { equipamentos }\end{array}$ & Custo $[\mathrm{R} \$]$ & $\begin{array}{l}\text { Custo de outros equipamentos necessários, de apoio e } \\
\text { transporte como tratores, conjunto semirreboque, } \\
\text { cavalo mecânico. }\end{array}$ \\
\hline \multicolumn{3}{|l|}{ Custos operacionais } \\
\hline Combustível / Energia & Custo $[\mathrm{R} \$]$ & $\begin{array}{l}\text { Custos anuais relacionados ao consumo de } \\
\text { combustível e energia. }\end{array}$ \\
\hline Mão-de-obra & Custo [R\$] & $\begin{array}{l}\text { Custos anuais gastos com mão-de-obra necessária para } \\
\text { os processos de recolhimento e cogeração de energia a } \\
\text { partir do palhiço }\end{array}$ \\
\hline Manutenção & Custo $[\mathrm{R} \$]$ & $\begin{array}{l}\text { Custos anuais relacionados à manutenção do } \\
\text { maquinário agrícola e industrial. }\end{array}$ \\
\hline $\begin{array}{l}\text { Outros custos } \\
\text { operacionais }\end{array}$ & Custo [R\$] & $\begin{array}{l}\text { Custos anuais relacionados a operações menores ou } \\
\text { eventuais. }\end{array}$ \\
\hline \multicolumn{3}{|l|}{ Variáveis agroindustriais } \\
\hline Umidade/ Densidade & Porcentagem [\%] & $\begin{array}{l}\text { Relacionado ao aumento de peso do palhiço no } \\
\text { transporte e a dificuldade de limpeza das impurezas. }\end{array}$ \\
\hline Qualidade do palhiço & Porcentagem [\%] & $\begin{array}{l}\text { Mensurada de acordo com o teor de impurezas } \\
\text { minerais. As impurezas prejudicam a eficiência de } \\
\text { cogeração de energia. }\end{array}$ \\
\hline $\begin{array}{l}\text { Eficiência de separação } \\
\text { cana/palhiço }\end{array}$ & Porcentagem [\%] & $\begin{array}{l}\text { Medida pela eficiência da estação de limpeza a seco } \\
\text { (para as colheitas integral e parcial) ou pelos } \\
\text { ventiladores da colhedora de cana (para o } \\
\text { enfardamento) }\end{array}$ \\
\hline $\begin{array}{l}\text { Produtividade da } \\
\text { cogeração }\end{array}$ & $\begin{array}{c}\text { MWh/tonelada de } \\
\text { palhiço }\end{array}$ & $\begin{array}{l}\text { Relacionada a energia produzida por tonelada de } \\
\text { palhiço }\end{array}$ \\
\hline $\begin{array}{l}\text { Valor esperado da } \\
\text { Receita }\end{array}$ & Receita [R\$] & $\begin{array}{l}\text { Receita anual da comercialização da energia. } \\
\text { Relacionada com o preço da energia no mercado e } \\
\text { com a produtividade de energia. Este é o único critério } \\
\text { que foi construído a partir de um modelo de árvore de } \\
\text { valor e probabilidades. }\end{array}$ \\
\hline
\end{tabular}


Após a definição dos critérios, é necessário agrupá-los em fatores (critérios de primeiro nível ou gerais) para ajudar o decisor organizar suas ideias quando muitos critérios estão disponíveis. No modelo são criados os critérios gerais “custos", "variáveis agroindustriais" e "valor esperado da receita". Depois, a estrutura é completada adicionando os subcritérios aos níveis superiores até formar a árvore de decisão.

Como resultado desta etapa, é obtida o conjunto de critérios que formam a estrutura hierárquica de objetivos apresentada pela Figura 10.

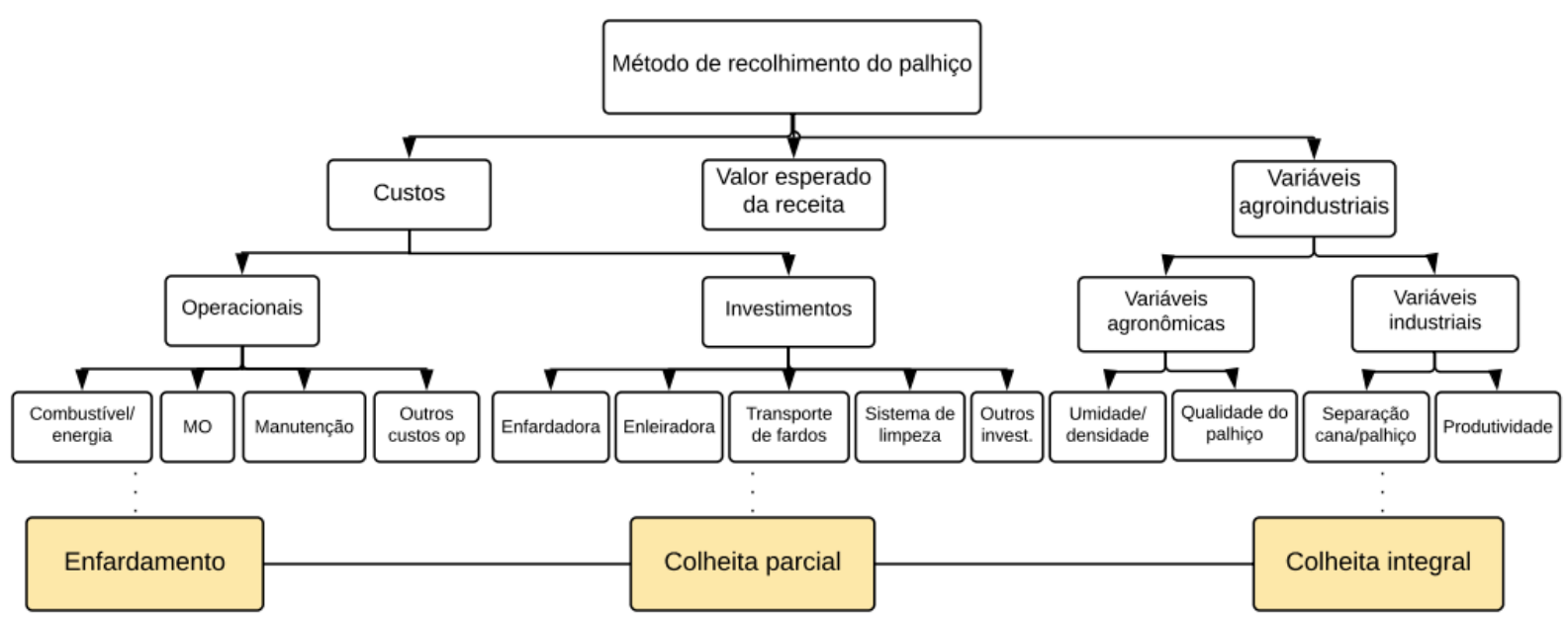

Figura 10: Estrutura hierárquica de objetivos

\subsection{Determinação das alternativas}

Essas soluções são estimadas a partir do contexto da pesquisa, como a revisão de literatura (principalmente o tópico 2.3.2, que se trata dos métodos de recolhimento do palhiço), participação em eventos sobre o tema, visitas e entrevistas com os decisores. Dessa forma são definidos três cursos de ação para o modelo multicritério para a decisão da alternativa de recolhimento com o palhiço de cana-de-açúcar: enfardamento, colheita integral e colheita parcial.

\subsection{Avaliação das alternativas para cada critério}

Esta etapa é a que demanda maior participação dos decisores. Ela consiste em definir a utilidade de cada critério considerando a aversão ao risco e as preferências intrínsecas dos decisores. 
Para cada um dos critérios, curvas de utilidade são desenhadas. Para o desenho dessas curvas são consideradas as médias das avaliações dos decisores. Estas funções permitem medir a preferência dos decisores de uma alternativa sobre outra e em relação a cada critério. As curvas são desenhadas por meio do método da certeza equivalente detalhado na Figura 8 da seção 3.2 e exemplificado no Apêndice B.

Assim, a partir de inquisições descritas na Figura 8, a curva de utilidade para o critério "Custo operacional de combustível/energia" é desenhada (Figura 11). Estas curvas são definidas nesta dissertação como curvas de utilidade de caráter linear para facilitar o julgamento dos decisores. O Quadro 13 apresenta os valores de custo e a sua utilidade equivalente, bem como a função de utilidade aproximada em função do custo.

Quadro 13: Utilidades do Custo de combustível

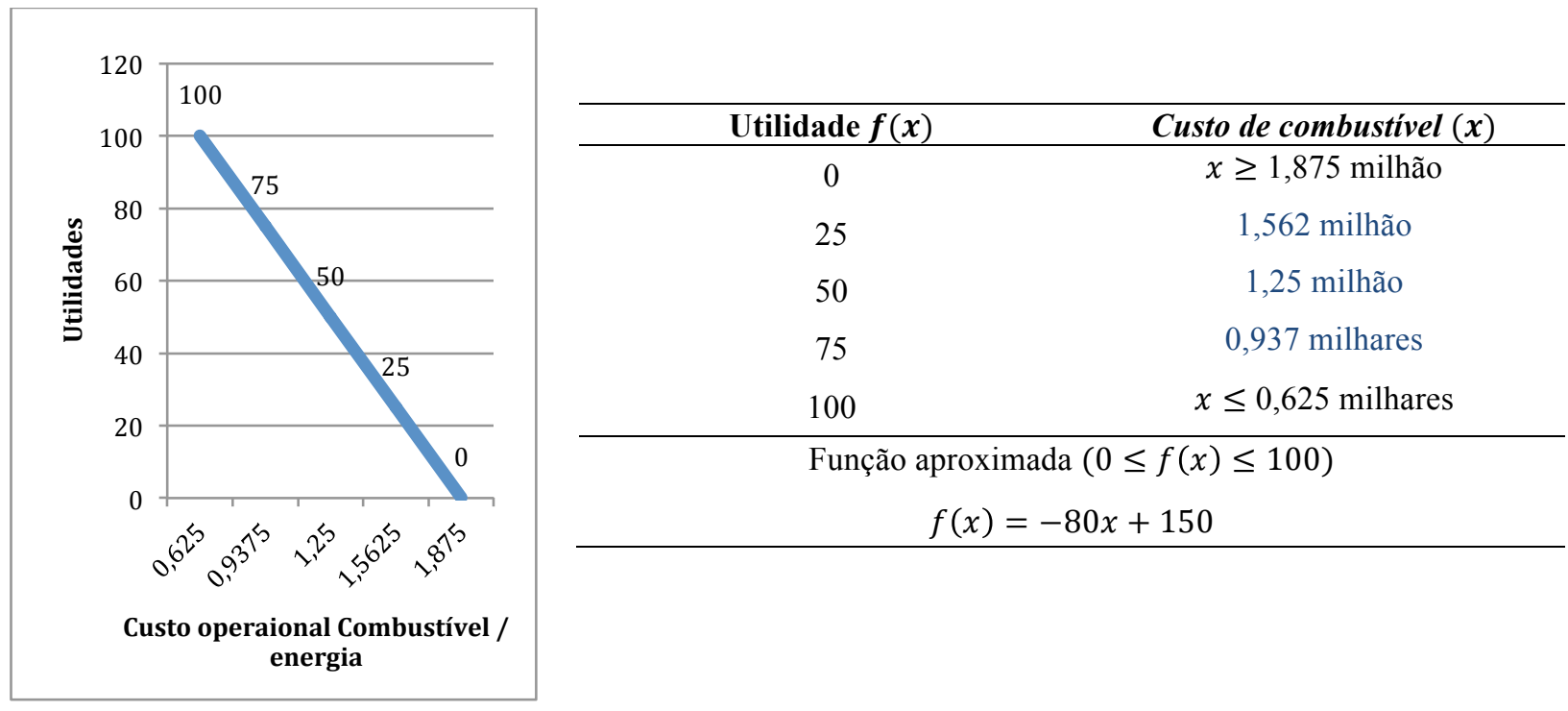

Figura 11: Função de utilidade do Custo combustível

As demais Figuras (12-24) e Quadros (14-26) são construídos a partir de inquisições semelhantes ao da Figura 11. 
Quadro 14: Utilidades do custo mão-de-obra

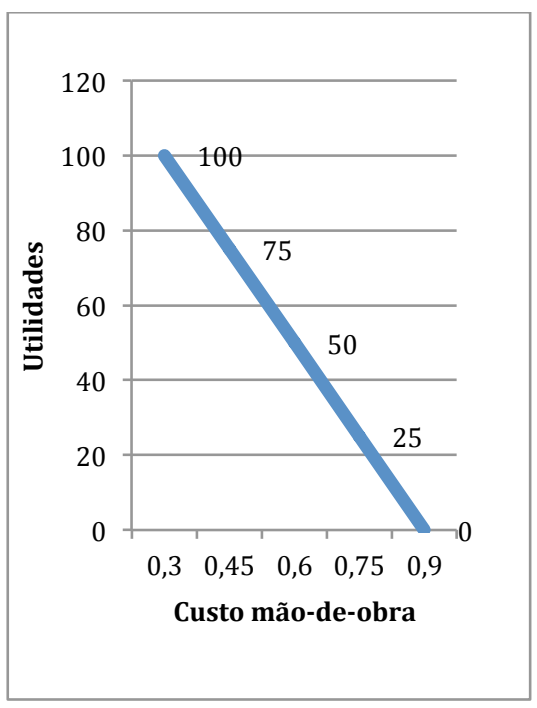

\begin{tabular}{cc}
\hline Utilidade $\boldsymbol{f}(\boldsymbol{x})$ & Custo de mão-de-obra $(\boldsymbol{x})$ \\
\hline 0 & $x \geq 0,9$ milhares \\
25 & 0,75 milhares \\
50 & 0,6 milhares \\
75 & 0,45 milhares \\
100 & $x \leq 0,3$ milhares
\end{tabular}

Função aproximada $(0 \leq f(x) \leq 100)$

$f(X)=-166,6 x+150$

Figura 12: Função utilidade do Custo mão-de-obra

Quadro 15: Utilidade do custo de manutenção

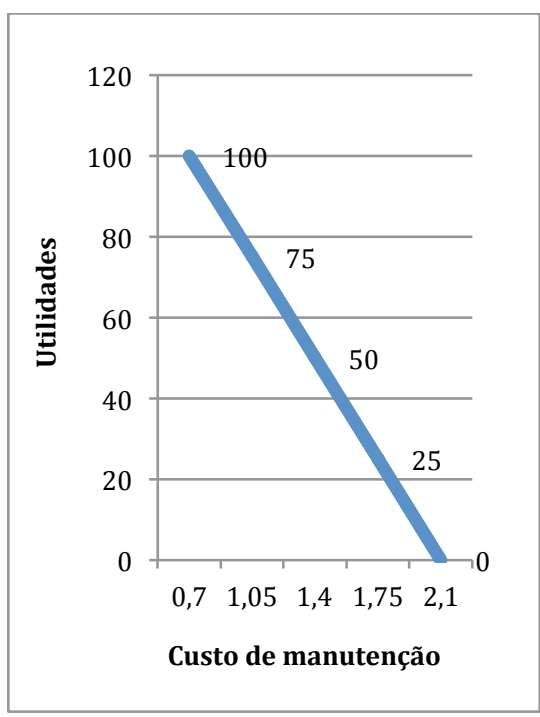

\begin{tabular}{cc}
\hline Utilidade $\boldsymbol{f}(\boldsymbol{x})$ & Custo de mão-de-obra $(\boldsymbol{x})$ \\
\hline 0 & $x \geq 2,1$ milhões \\
25 & 1,75 milhão \\
50 & 1,4 milhão \\
75 & 1,05 milhão \\
100 & $x \leq 0,7$ milhares
\end{tabular}

Função aproximada $(0 \leq f(x) \leq 100)$

$f(X)=-71,43 x+150$

Figura 13: Função utilidade do Custo manutenção 
Quadro 16: Utilidade dos outros custos operacionais

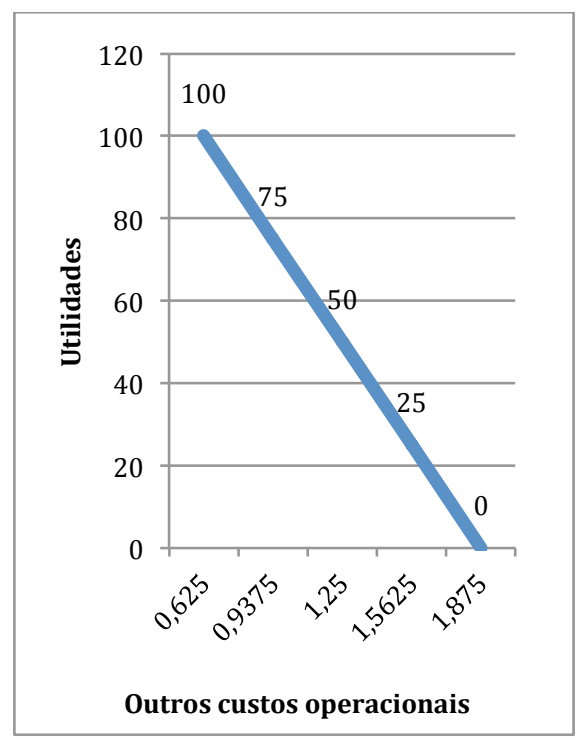

\begin{tabular}{cc}
\hline Utilidade $\boldsymbol{f}(\boldsymbol{x})$ & Outros custos operacionais $(\boldsymbol{x})$ \\
\hline 0 & $x \geq 1,875$ milhão \\
25 & 1,5625 milhão \\
50 & 1,25 milhão \\
75 & 0,9375 milhares \\
100 & $x \leq 0,625$ milhares
\end{tabular}

Função aproximada $(0 \leq f(x) \leq 100)$

$f(X)=-80 x+150$

Figura 14: Função utilidade dos outros custos operacionais

Quadro 17: Utilidade do custo enfardadora

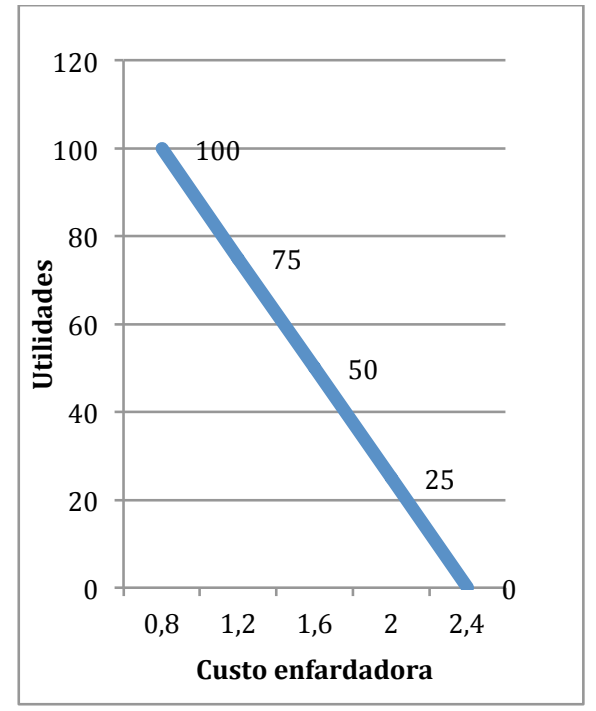

\begin{tabular}{cc}
\hline Utilidade $\boldsymbol{f}(\boldsymbol{x})$ & Custo enfardadora $(\boldsymbol{x})$ \\
\hline 0 & $x \geq 2,4$ milhões \\
25 & 2 milhões \\
50 & 1,6 milhão \\
75 & 1,2 milhão \\
100 & $x \leq 0,8$ milhares \\
\hline
\end{tabular}

Função aproximada $(0 \leq f(x) \leq 100)$

$$
f(X)=-62,5 x+150
$$

Figura 15: Função utilidadde do custo enfardadora 
Quadro 18: Utilidades do custo enleiradora

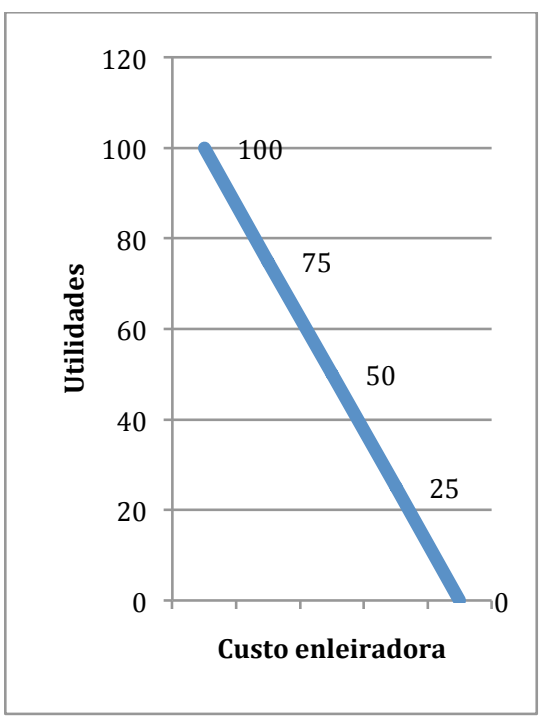

\begin{tabular}{cc}
\hline Utilidade $\boldsymbol{f}(\boldsymbol{x})$ & Custo enleiradora $(\boldsymbol{x})$ \\
\hline 0 & $x \geq 0,375$ milhares \\
25 & 0,3125 milhares \\
50 & 0,25 milhares \\
75 & 0,1875 milhares \\
100 & $x \leq 0,125$ milhares
\end{tabular}

Função aproximada $(0 \leq f(x) \leq 100)$

$$
f(X)=-400 x+150
$$

Figura 16: Função utilidade do custo enleiradora

Quadro 19: Utilidades do custo transporte de fardos

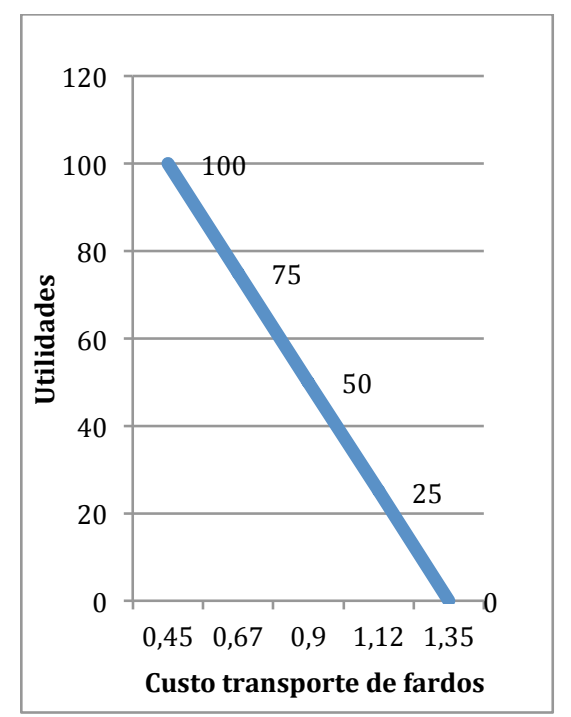

\begin{tabular}{cc}
\hline Utilidade $\boldsymbol{f}(\boldsymbol{x})$ & Custo transporte de fardos $(\boldsymbol{x})$ \\
\hline 0 & $x \geq 1,35$ milhão \\
25 & 1,12 milhão \\
50 & 0,9 milhares \\
75 & 0,67 milhares \\
100 & $x \leq 0,45$ milhares \\
\hline \multicolumn{2}{c}{ Função aproximada $(0 \leq f(x) \leq 100)$} \\
\multicolumn{2}{c}{$f(X)=-111,1 x+150$}
\end{tabular}

Figura 17: Função utilidade do custo transporte de fardos 
Quadro 20: Utilidades do custo do sistema de limpeza

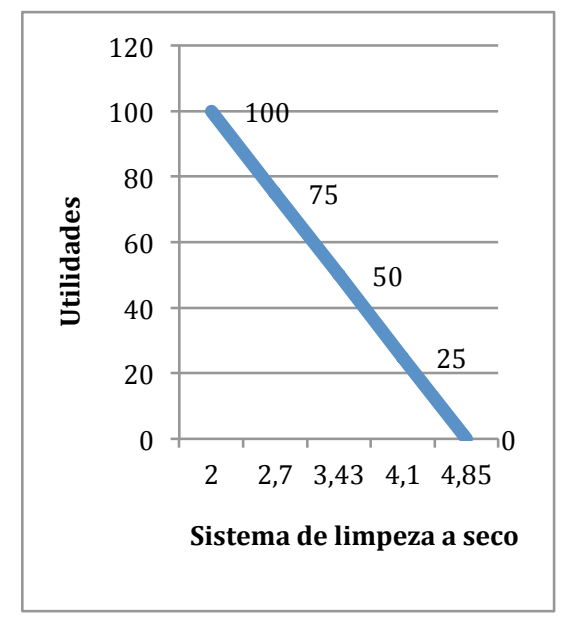

\begin{tabular}{cc}
\hline Utilidade $\boldsymbol{f}(\boldsymbol{x})$ & Custo sistema de limpeza $(\boldsymbol{x})$ \\
\hline 0 & $x \geq 4,85$ milhões \\
25 & 4,1 milhões \\
50 & 3,43 milhões \\
75 & 2,7 milhões \\
100 & $x \leq 2$ milhões \\
\hline Função aproximada $(0 \leq f(x) \leq 100)$ \\
\\
\end{tabular}

Figura 18: Função utilidade do custo do sistema de limpeza a seco

Quadro 21: Utilidades dos outros custos de investimentos

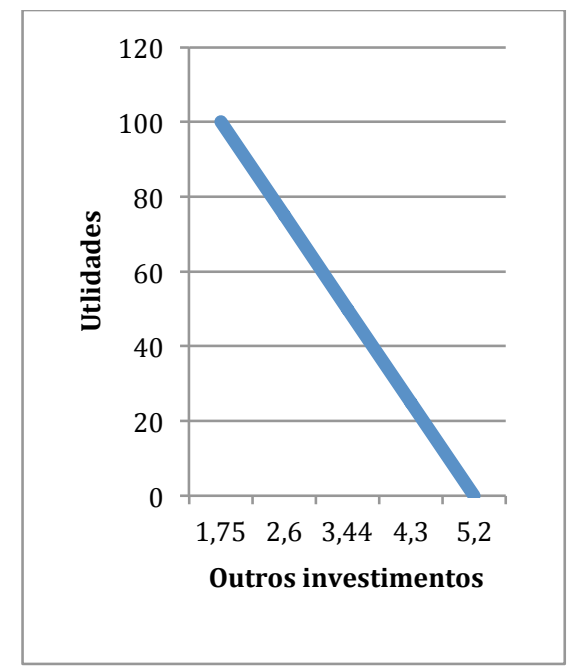

\begin{tabular}{cc}
\hline Utilidade $\boldsymbol{f}(\boldsymbol{x})$ & Outros investimentos $(\boldsymbol{x})$ \\
\hline 0 & $x \geq 5,2$ milhões \\
25 & 4,3 milhões \\
50 & 3,44 milhões \\
75 & 2,6 milhões \\
100 & $x \leq 1,75$ milhão \\
\hline Função aproximada $(0 \leq f(x) \leq 100)$ \\
\\
$\quad f(x)=-29 x+150$
\end{tabular}

Figura 19: Função utilidade dos outros custos de investimento 
Quadro 22: Utilidades da umidade

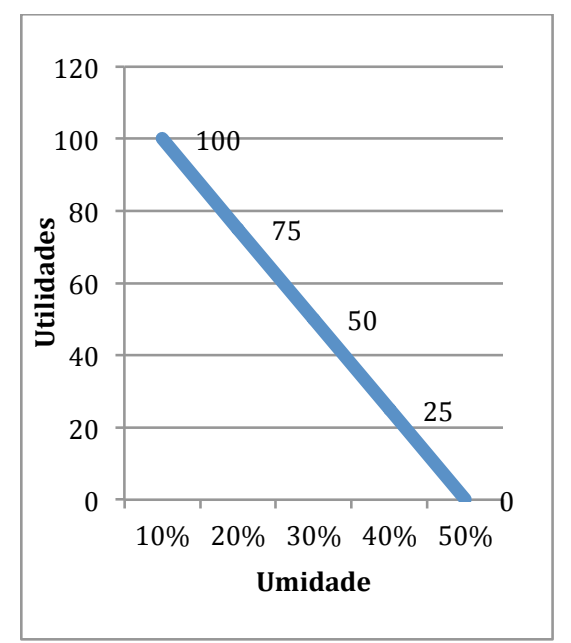

\begin{tabular}{cc}
\hline Utilidade $\boldsymbol{f}(\boldsymbol{x})$ & Umidade $(\boldsymbol{x})$ \\
\hline 0 & $x \geq 50 \%$ \\
25 & $40 \%$ \\
50 & $30 \%$ \\
75 & $20 \%$ \\
100 & $x \leq 10 \%$ \\
\hline \multicolumn{2}{c}{ Função aproximada $(0 \leq f(x) \leq 100)$} \\
\multicolumn{2}{c}{$f(X)=-250 x+125$} \\
\hline
\end{tabular}

Figura 20: Função utilidade da umidade

Quadro 23: Utilidades da produtividade

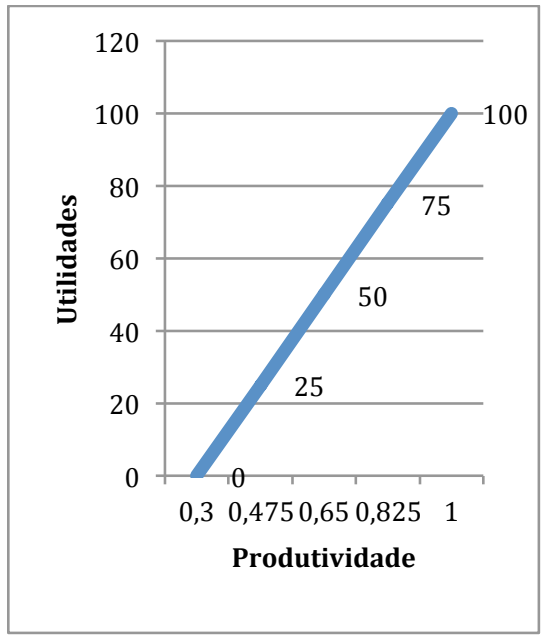

\begin{tabular}{cc}
\hline Utilidade $\boldsymbol{f}(\boldsymbol{x})$ & Produtividade $(\boldsymbol{x})$ \\
\hline 0 & $x \leq 0,3 \mathrm{MWh} / \mathrm{t}$ palhiço \\
25 & $0,475 \mathrm{MWh} / \mathrm{t}$ palhiço \\
50 & $0,65 \mathrm{MWh} / \mathrm{t}$ palhiço \\
75 & $0,825 \mathrm{MWh} / \mathrm{t}$ palhiço \\
100 & $x \geq 1 \mathrm{MWh} / \mathrm{t}$ palhiço \\
\hline Função aproximada $(0 \leq f(x) \leq 100)$ \\
\multicolumn{2}{c}{$f(X)=142,86 x-42,86$}
\end{tabular}

Figura 21: Função utilidade da produtividade 
Quadro 24: Utilidades do teor de impureza

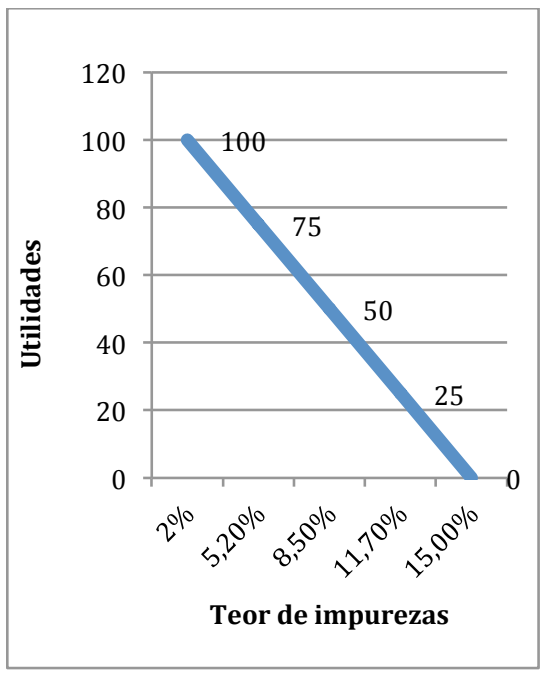

\begin{tabular}{cc}
\hline Utilidade $\boldsymbol{f}(\boldsymbol{x})$ & Teor de impurezas $(\boldsymbol{x})$ \\
\hline 0 & $x \geq 15 \%$ \\
25 & $11,7 \%$ \\
50 & $8,5 \%$ \\
75 & $5,2 \%$ \\
100 & $x \leq 2 \%$ \\
\hline Função aproximada $(0 \leq f(x) \leq 100)$ \\
\multicolumn{2}{c}{$f(X)=-769,2 x+115,38$}
\end{tabular}

Figura 22: Função utilidade do teor de impurezas

Quadro 25: Utilidades da eficiência de separação cana/palhiço

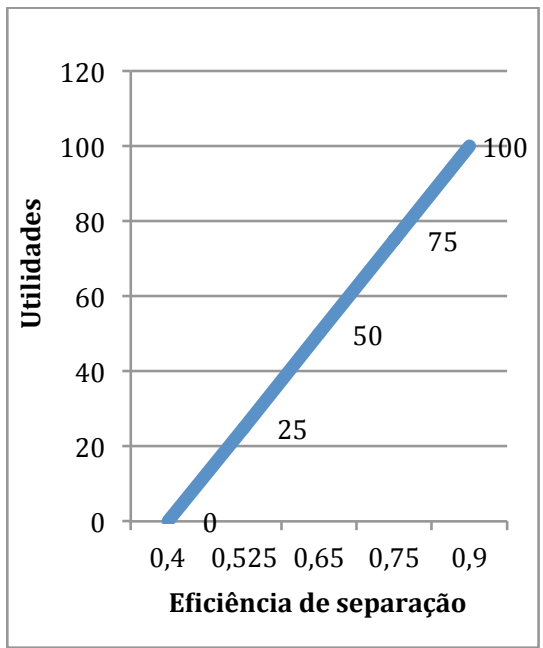

\begin{tabular}{cc}
\hline Utilidade $\boldsymbol{f}(\boldsymbol{x})$ & $\begin{array}{c}\text { Eficiência de separação } \\
\text { cana/palhiço(x) }\end{array}$ \\
\hline 0 & $x \leq 40 \%$ \\
25 & $52,5 \%$ \\
50 & $65 \%$ \\
75 & $75 \%$ \\
100 & $x \geq 90 \%$ \\
\hline \multicolumn{2}{c}{$f(X)=200 x-80$} \\
\hline
\end{tabular}

Figura 23: Função utilidade da eficiência de separação cana/palhiço 


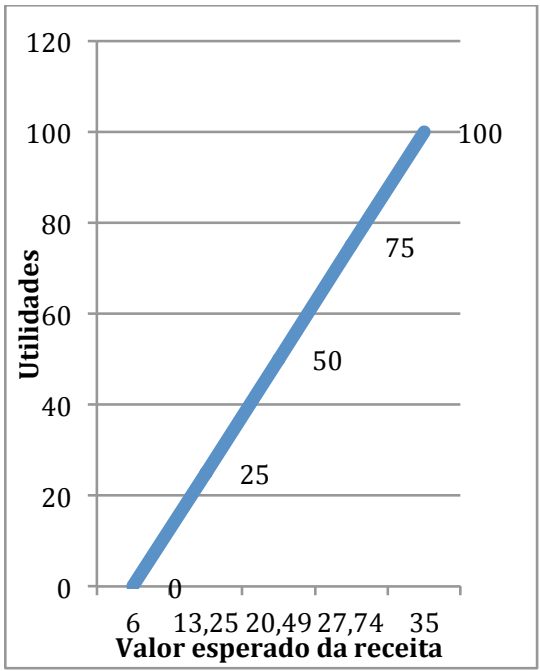

\begin{tabular}{cc}
\hline Utilidade $\boldsymbol{f}(\boldsymbol{x})$ & Valor esperado da receita $(\boldsymbol{x})$ \\
\hline 0 & $x \leq 6$ \\
25 & 13,25 milhões \\
50 & 20,49 milhões \\
75 & 27,74 milhões \\
100 & $x \geq 35$ milhões \\
\hline Função aproximada $(0 \leq f(x) \leq 100)$ \\
\multicolumn{2}{c}{$f(X)=3,45 x-20,7$} \\
\hline
\end{tabular}

Figura 24: Função utilidade do valor esperado da receita

\subsubsection{Cálculo do valor esperado da receita das alternativas de recolhimento de palhiço}

Por meio da árvore de valor é possível calcular o valor esperado da receita para cada alternativa de recolhimento de palhiço considerando os possíveis preços da energia no mercado e suas probabilidades.

As usinas típicas do setor geram em média $0,8 \mathrm{MWh}$ de energia por tonelada de palhiço a partir da operação de enfardamento. Para a colheita integral e parcial, essa produtividade cai para 0,7 MWh de energia por tonelada de palhiço. Elas produzem em média 100.000 toneladas de palhiço anuais, escala ideal para uma unidade de processamento de fardos e de colheita integral. Já para a colheita parcial seria recolhida metade dessa quantidade de palhiço, 50.000 toneladas, pois boa parte do palhiço disponível no campo permanece no solo durante a colheita da cana ao ser ligado um dos sistemas de ventiladores da colhedora.

Calcula-se a partir desses dados, o valor esperado da receita por safra para as três alternativas de recolhimento de palhiço (enfardamento, colheita integral e colheita parcial) considerando as probabilidadades e a média dos preços da energia dos anos de 2014 a 2017.

\section{1) Enfardamento}

Produção de excedente de energia: 0,8 MWh/t x 100.000t = 80.000 MWh 
Quadro 27: Cálculo do valor esperado da receita para a alternativa de enfardamento

\begin{tabular}{llll}
\hline $\begin{array}{l}\text { Preço da energia } \\
(\mathbf{R} \$ \mathbf{M W h})\end{array}$ & $\begin{array}{l}\text { Produção de } \\
\text { excedente (MWh) }\end{array}$ & Receita (R\$) & E (Receita) \\
\hline 50,00 & 80.000 & 4.000 .000 & 584.000 \\
150,00 & 80.000 & 12.000 .000 & 2.496 .000 \\
\hline 250,00 & 80.000 & 20.000 .000 & 2.920 .000 \\
350,00 & 80.000 & 28.000 .000 & 4.676 .000 \\
450,00 & 80.000 & 36.000 .000 & 2.268 .000 \\
\hline 550,00 & 80.000 & 44.000 .000 & 3.652 .000 \\
650,00 & 80.000 & 52.000 .000 & 1.092 .000 \\
750,00 & 80.000 & 60.000 .000 & 3.780 .000 \\
\hline 850,00 & 80.000 & 68.000 .000 & 7.072 .000 \\
\hline Total & & & 28.540 .000 \\
\hline
\end{tabular}

\section{2) Colheita integral}

Produção de excedente de energia: 0,7 MWh/t x 100.000t $=70.000 \mathrm{MWh}$

Quadro 28: Cálculo do valor esperado da receita para a alternativa de colheita integral

\begin{tabular}{llll}
\hline $\begin{array}{l}\text { Preço da energia } \\
\text { (R\$) }\end{array}$ & $\begin{array}{l}\text { Produção de } \\
\text { excedente (MWh) }\end{array}$ & Receita (R\$) & (E) Receita \\
\hline 50,00 & 70.000 & 3.500 .000 & 511.000 \\
150,00 & 70.000 & 10.500 .000 & 2.184 .000 \\
\hline 250,00 & 70.000 & 17.500 .000 & 2.555 .000 \\
\hline 350,00 & 70.000 & 24.500 .000 & 4.091 .500 \\
450,00 & 70.000 & 31.500 .000 & 1.984 .500 \\
\hline 550,00 & 70.000 & 38.500 .000 & 3.195 .500 \\
\hline 650,00 & 70.000 & 45.500 .000 & 955.500 \\
\hline 750,00 & 70.000 & 52.500 .000 & 3.307 .500 \\
\hline 850,00 & 70.000 & 59.500 .000 & 6.188 .000 \\
\hline Total & & & 24.972 .500 \\
\hline
\end{tabular}




\section{3) Colheita parcial}

Produção de excedente de energia: 0,7 MWh/t x 50.000t = 35.000 MWh

Quadro 29: Cálculo do valor esperado da receita para a alternativa de colheita parcial

\begin{tabular}{llll}
\hline $\begin{array}{l}\text { Preço da energia } \\
(\mathbf{R})\end{array}$ & $\begin{array}{l}\text { Produção de } \\
\text { excedente }(\mathbf{M W h})\end{array}$ & Receita (R\$) & (E) Receita \\
\hline 50,00 & 35.000 & 1.750 .000 & 255.500 \\
150,00 & 35.000 & 5.250 .000 & 1.092 .000 \\
250,00 & 35.000 & 8.750 .000 & 1.277 .500 \\
350,00 & 35.000 & 12.250 .000 & 2.045 .750 \\
450,00 & 35.000 & 15.750 .000 & 992.250 \\
550,00 & 35.000 & 19.250 .000 & 1.597 .750 \\
650,00 & 35.000 & 22.750 .000 & 477.750 \\
750,00 & 35.000 & 26.250 .000 & 1.653 .750 \\
850,00 & 35.000 & 29.750 .000 & 3.094 .000 \\
Total & & & 12.486 .250 \\
\hline
\end{tabular}

Estão explícitos na árvore de valor e probabilidades na Figura 25 os valores esperados da receita de cada ramo e o valor esperado de cada alternativa de recolhimento de palhiço. 


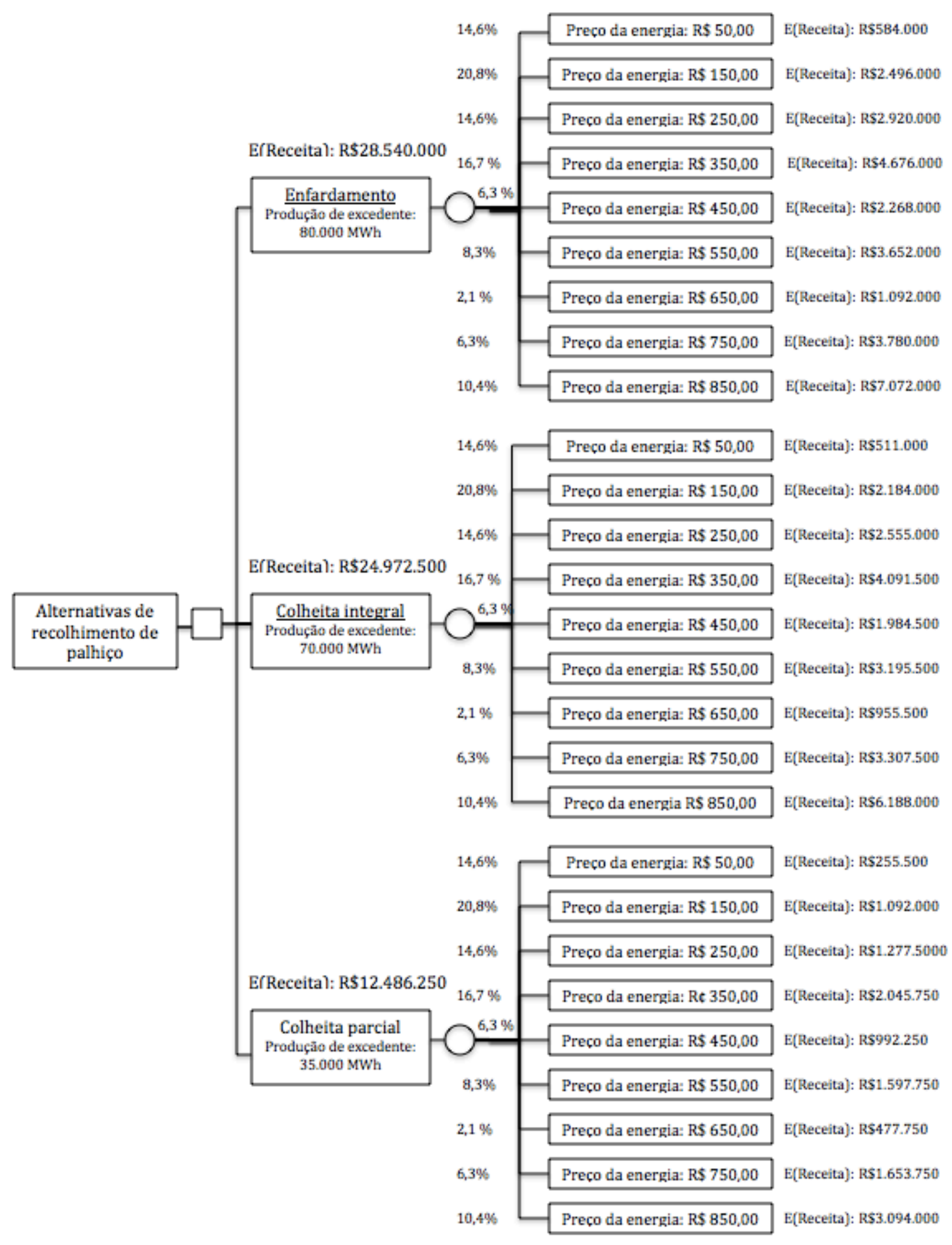

Figura 25: árvore baseada em valor e probabilidades

Portanto, o valor esperado da receita para a alternativa de enfardamento da usina do estudo é R \$ 28.540.000, para a colheita integral o valor encontrado é de R\$24.972.500 e para a colheita parcial R\$ 12.486.250, como apresentado na Quadro 30: 
Quadro 30: Valor esperado da receita da venda de energia

\begin{tabular}{cc}
\hline Alternativas de recolhimento de palhiço & Valor esperado da receita: E (Receita) \\
\hline Enfardamento & $\mathrm{R} \$ 28.540 .000$ \\
Colheita integral & $\mathrm{R} \$ 24.972 .500$ \\
Colheita parcial & $\mathrm{R} \$ 12.486 .250$ \\
\hline
\end{tabular}

\subsection{Hierarquização dos critérios}

Essa etapa visa obter a ordem de classificação dos critérios. Essa ponderação foi realizada através do método SMART. Os Quadros 31 a 37 resumem os resultados para os julgamentos dos decisores. Uma média desses julgamentos foi utilizada.

Quadro 31: Julgamentos para os critérios gerais

\begin{tabular}{ccc}
\hline Critérios & Julgamento & Pesos \\
\hline Custos & 20 & 0,4 \\
Valor esperado da receita & 20 & 0,4 \\
Variáveis agroindustriais & 10 & 0,2 \\
Total & 50 & 1,0 \\
\hline
\end{tabular}

Do Quadro 31, observa-se a preferência do custo e receita em relação às variáveis agroindustriais. Pois para os decisores, um baixo custo e uma alta receita em geral podem garantir um bom desempenho das variáveis agroindustriais. Desta forma, para os respondentes, os custos representam $40 \%$ do desempenho do sistema de cogeração e venda de excedentes de energia com o palhiço de cana, enquanto o valor esperado da receita também é julgado com uma ponderação de $40 \%$ e as variáveis agroindustriais com $20 \%$.

Quadro 32: Julgamentos para os critérios de Custo

\begin{tabular}{ccc}
\hline Critérios & Julgamento & Pesos \\
\hline Custos operacionais & 15 & 0,6 \\
Custos de investimento & 10 & 0,4 \\
Total & 25 & 1,0 \\
\hline
\end{tabular}

Para os custos envolvidos, as ponderações do Quadro 32 mostram a relevância dada pelos decisores para os custos operacionais, com $60 \%$ de preferência. Segundo os respondentes baixos custos operacionais garantem o retorno à usina ano a ano. Por outro lado, 
custos operacionais constantemente baixos comprometem o bom funcionamento do sistema. Ao julgar os custos de investimento com ponderação de $40 \%$, os decidores afirmam que um bom investimento de fato é o primeiro passo para alavancar o negócio, porém o investimento insatisfatório pode ser recuperado a longo prazo.

Quadro 33: Julgamentos para os critérios de Variáveis agroindustriais

\begin{tabular}{ccc}
\hline Critérios & Julgamento & Pesos \\
\hline Variáveis agronômicas & 10 & 0,5 \\
Variáveis industriais & 10 & 0,5 \\
Total & 20 & 1,0 \\
\hline
\end{tabular}

Com base na ponderação das variáveis agroindustriais, os decisores destacam uma igual importância para as variáveis agronômicas e industriais, cada uma com peso de 50\%.

Quadro 34: Julgamento para os critérios de Custos operacionais

\begin{tabular}{ccc}
\hline Critérios & Julgamento & Pesos \\
\hline Custo de combustível/ & 20 & 0,31 \\
energia & 15 & 0,23 \\
Custo de mão-de-obra & 20 & 0,30 \\
Custo de manutenção & 10 & 0,16 \\
Outros custos operacionais & 65 & 1,00 \\
\hline Total & 65
\end{tabular}

Segundo a ponderação dos decisores, baixos custos operacionais de combustível e manutenção dos equipamentos representam um bom desempenho do sistema em pelo menos $61 \%$ das vezes. Isto indica que os decisores estão dispostos a dar maior valor para aquelas soluções que forneçam um melhor desempenho nas operações básicas do transporte em procura de garantir a eficácia e eficiência. Além disso, esses critérios estão associados a atividades de alto custo para a cogeração de energia a partir do palhiço. Por outro lado, os custos com mão-de-obra e outros custos operacionais foram considerados de menor relevância. 
Quadro 35: Julgamento para os critérios de Custos de investimentos

\begin{tabular}{ccc}
\hline Critérios & Julgamento & Pesos \\
\hline Custo da enfardadora & 30 & 0,230 \\
Custo da enleiradora & 10 & 0,077 \\
Custo de transporte de fardos & 35 & 0,270 \\
Custo do sistema de limpeza & 40 & 0,300 \\
seco & & \\
Outros custos de investimento & 15 & 0,123 \\
Total & 130 & 1,000 \\
\hline
\end{tabular}

Relativo aos custos de investimento, o critério de sistema de limpeza a seco teve maior prioridade, com 40\%. Isso ocorreu pois este sistema, além de ter um alto custo de investimento, é fundamental para a cogeração a partir do recolhimento integral de palhiço e a maioria das usinas não possui. Seguidos desse critério, o transporte de fardos e a enfardadora tiveram uma preferência de $35 \%$ e $30 \%$, respectivamente, pois são máquinas de alto custo para o sistema. Com uma menor prioridada dada pelos decisores, ficaram os critérios de custo da enleiradora e outros custos investimentos.

Quadro 36: Julgamentos para os critérios de Variáveis agronômicas

\begin{tabular}{ccc}
\hline Critérios & Julgamento & Pesos \\
\hline Umidade & 10 & 0,44 \\
Qualidade do palhiço & 12,5 & 0,56 \\
Total & 22,5 & 1,00 \\
\hline
\end{tabular}

Em relação aos julgamentos das variáveis agronômicas, os decisores ressaltaram a importância da qualidade do palhiço (56\%), ou seja, do baixo teor de impurezas presentes na biomassa. Esse julgamento se deve ao fato do alto teor de impurezas prejudicar a alimentação das caldeiras bem como interferir na produtividade de energia. Por outro lado, ainda com um grande valor, os decisores julgaram a umidade do palhiço com 44\% de importância. 
Quadro 37: Julgamentos para os critérios de Variáveis industriais

\begin{tabular}{lcc}
\hline \multicolumn{1}{c}{ Critérios } & Julgamento & Pesos \\
\hline Eficiência de separação & 10 & 0,4 \\
cana-palhiço & & \\
Produtividade de cogeração & 15 & 0,6 \\
Total & 25 & 1,0 \\
\hline
\end{tabular}

Referente às variáveis industriais, os decisores avaliaram a produtividade de cogeração de energia com maior pontuação, $60 \%$ da sua preferência. Foi dada a importância de $40 \%$ à eficiência de separação cana/palhiço.

Assim, pode ser concluído que os decisores dão maior preferência para aquelas soluções de baixo custo (principalmente custos operacionais) e maior valor esperado de receita, no entanto critérios de variáveis agroindustriais (como a qualidade do palhiço e produtividade de energia elétrica) também têm alto grau de influência na decisão final. Sendo assim, a decisão de escolha entre as alternativas de recolhimento de palhiço não é motivada unicamente em relevância aos custos relevantes. A Figura 26 apresenta a estrutura hierárquica de objetivos com os pesos incorporados. 


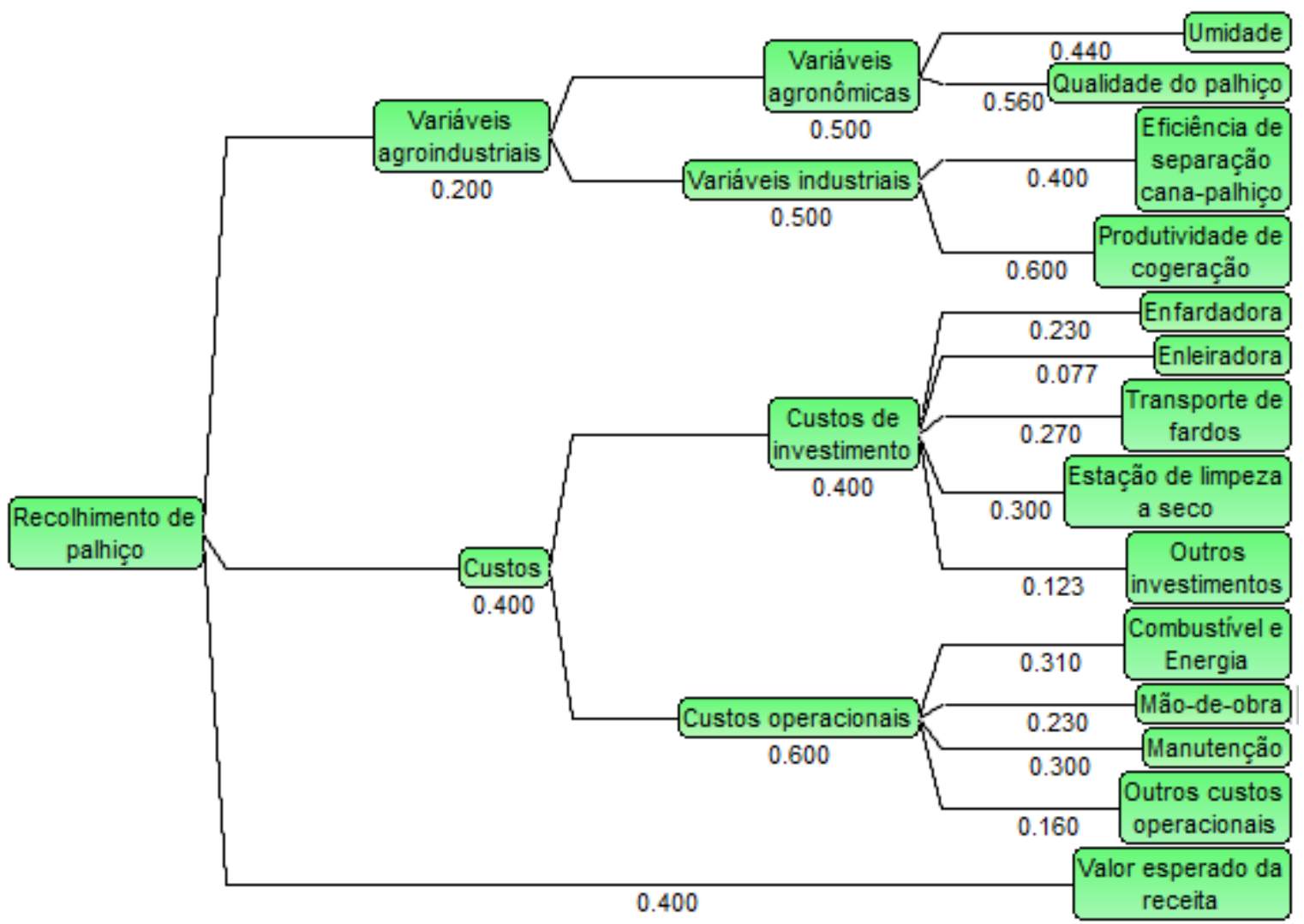

Figura 26: Estrutura hierárquica de objetivos com pesos integrados

\subsection{Avaliação das alternativas}

Após a construção da árvore de decisão, a incorporação dos pesos e respectivas funções de utilidade dos critérios, é realizada a avaliação das alternativas.

A Figura 27 representa a avaliação de utilidade geral para as alternativas consideradas. Esta avaliação está fundamentada na função de utilidade multiatributo global (apresentada na seção 2.4). Os resultados são fornecidos em uma escala de 0 a 100\%, indicando a porcentagem em que a alternativa se desempenha com relação a todos os critérios.

Os resultados indicam as alternativas de enfardamento e colheita integral com o mesmo desempenho. Ambas atingindo $64 \%$ do objetivo geral. Entende-se que o modelo escolheu essas soluções como as mais adequadas para o objetivo de maximizar o desempenho de recolhimento de palhiço com relação às prioridades e aversão ao risco dos tomadores de decisão. O modelo apresenta a colheita parcial com 54\% de utilidade. 


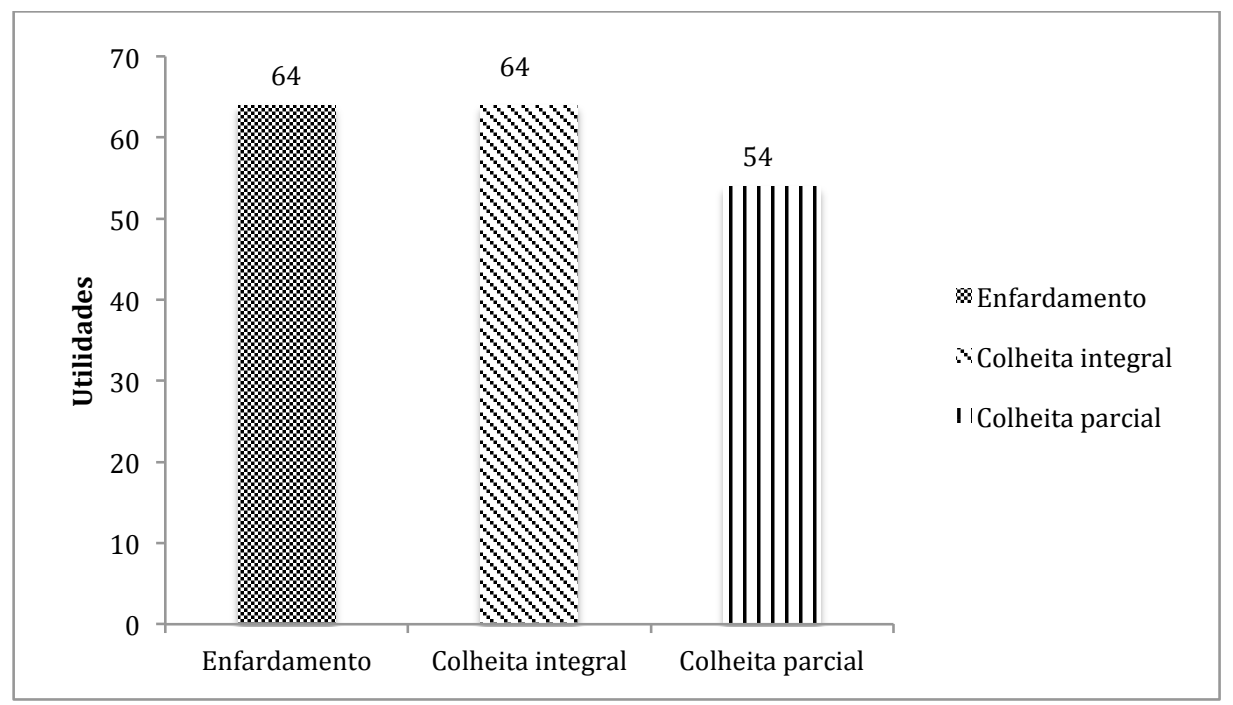

Figura 27: Avaliação geral das alternativas

A Figura 28 apresenta as utilidades para os critérios "custo" e "variáveis agroindustriais". Observa-se que enquanto a alternativa de colheita parcial apresenta o melhor desempenho para o critério "custo", a alternativa de enfardamento tem a maior utilidade para as "variáveis agroindustriais". No entanto, o enfardamento tem a pior preferência para os "custos". Já a alternativa de colheita integral teve um desempenho mediano tanto para o critério "custos" quanto para as "variáveis agroindustriais".

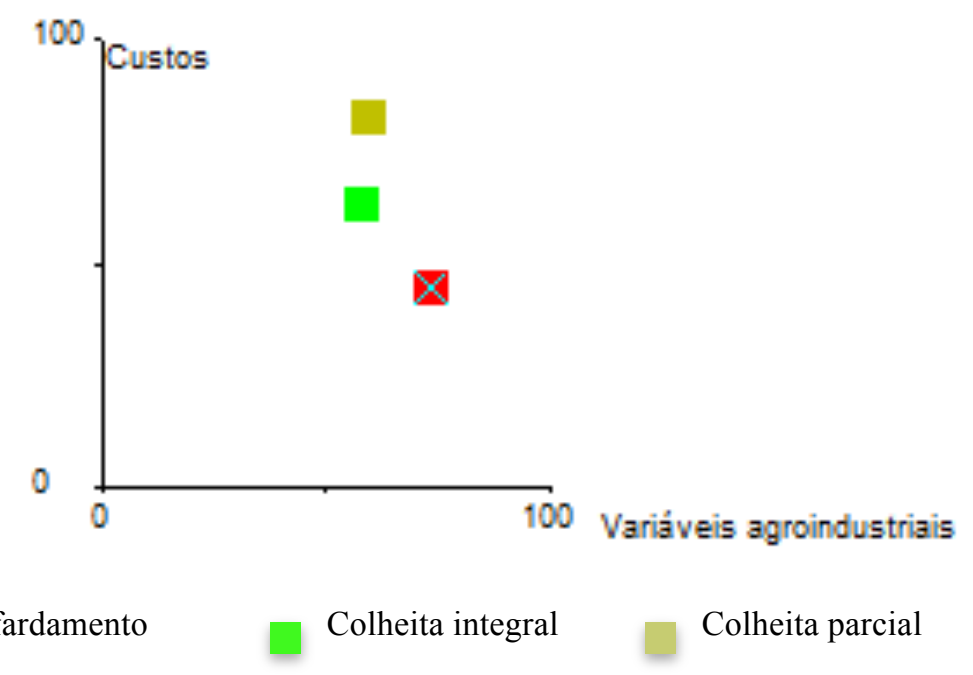

Figura 28: Avaliação custos x variáveis agroindustriais

A Figura 29 apresenta as utilidades para os critérios "custo" e "valor esperado da receita". Observa-se que enquanto a alternativa colheita parcial apresenta o melhor desempenho para o "custo", apresenta também o pior desempenho para "valor esperado da 
receita". Por outro lado, enquanto a alternativa de enfardamento tem a melhor preferência para o critério "valor esperado da receita", ela também tem o pior desempenho para os custos. Isso é explicado pelo fato que muitas aquisições devem ser feitas pelas usinas para o bom funcionamento da alternativa de enfardamento de palhiço, porém sua produtividade de energia é maior, resultando em uma maior receita. Já a colheita integral apresentou resultados com um desempenho intermediário para os "custo" e uma alta utilidade para o "valor esperado da receita".

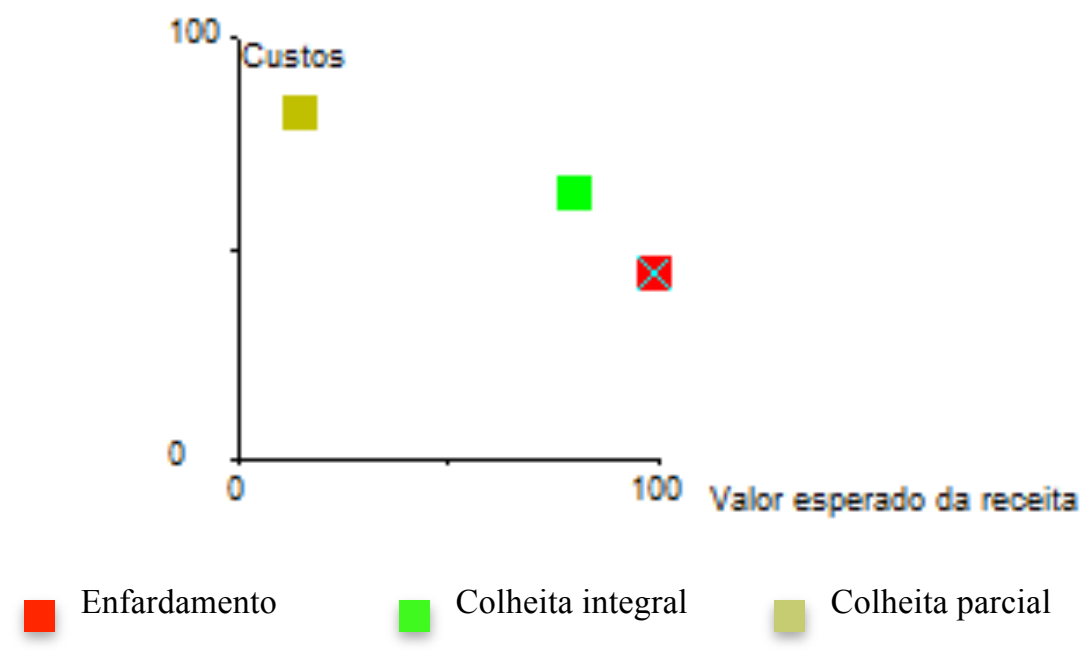

Figura 29: Avaliação valor esperado da receita x custos

O pior desempenho do enfardamento para os custos pode ser ilustrado pela Figura 30 que apresenta o comportamento das alternativas de desempenho para o critério "custos". A Figura 30 mostra que o enfardamento atinge $44 \%$ do objetivo geral de custos. A Figura 31 apresenta os custos operacionais, que tem uma utilidade menor para o enfardamento por necessitar de uma maior quantidade de mão-de-obra, além de ter um maior consumo de combustíveis pelos veículos que operam e ter mais gastos com manutenção de veículos. A Figura 32 apresenta os custos de investimentos e mostra uma menor utilidade para o enfardamento, com um desempenho semelhante para a colheita integral e parcial. Isso acontece pois um maior número de equipamentos e veículos devem ser adquiridos pela usina para a colheita com enfardamento e praticamente os mesmos investimentos devem ser feitos para a colheita integral e parcial, sendo um pouco menor a quantidade de frota investida para a colheita parcial. 


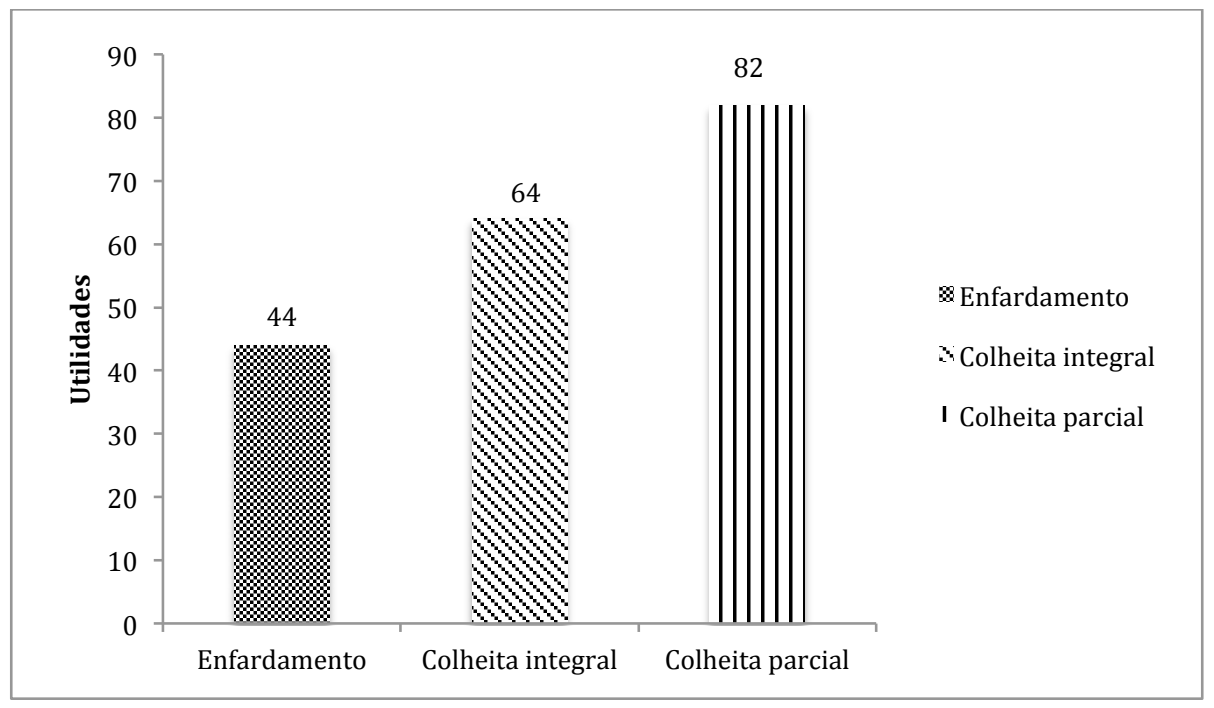

Figura 30: Avaliação do critério "custo"

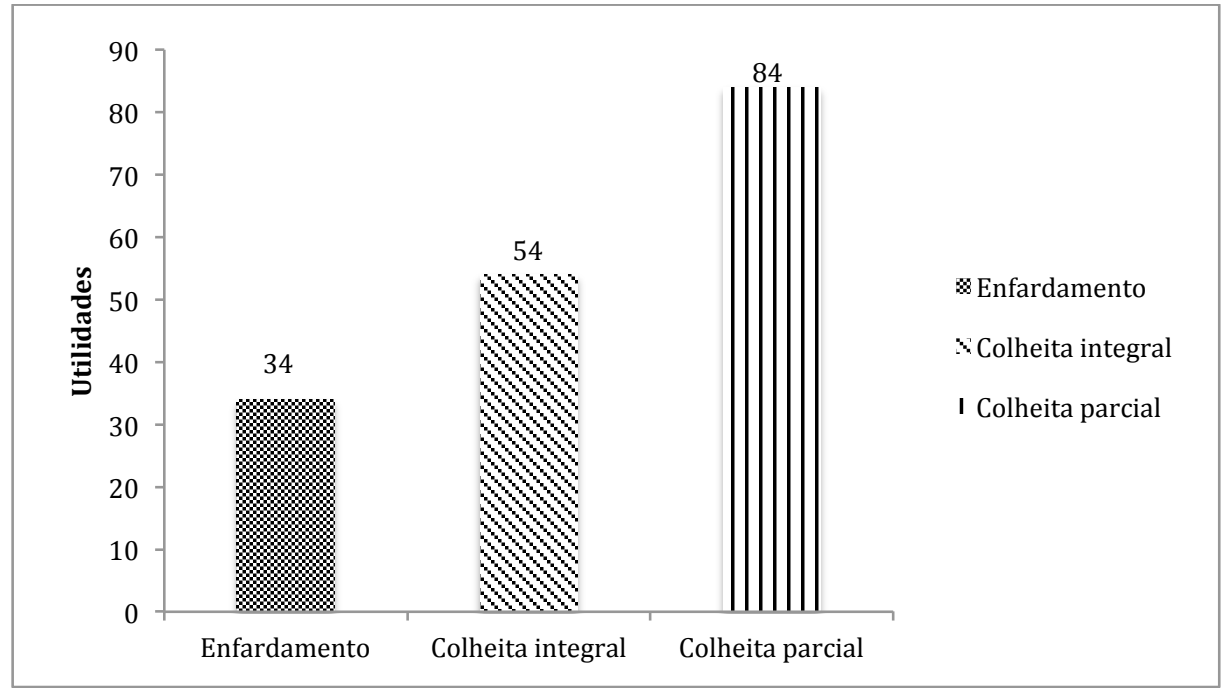

Figura 31: Avaliação do critério "custo operacional”

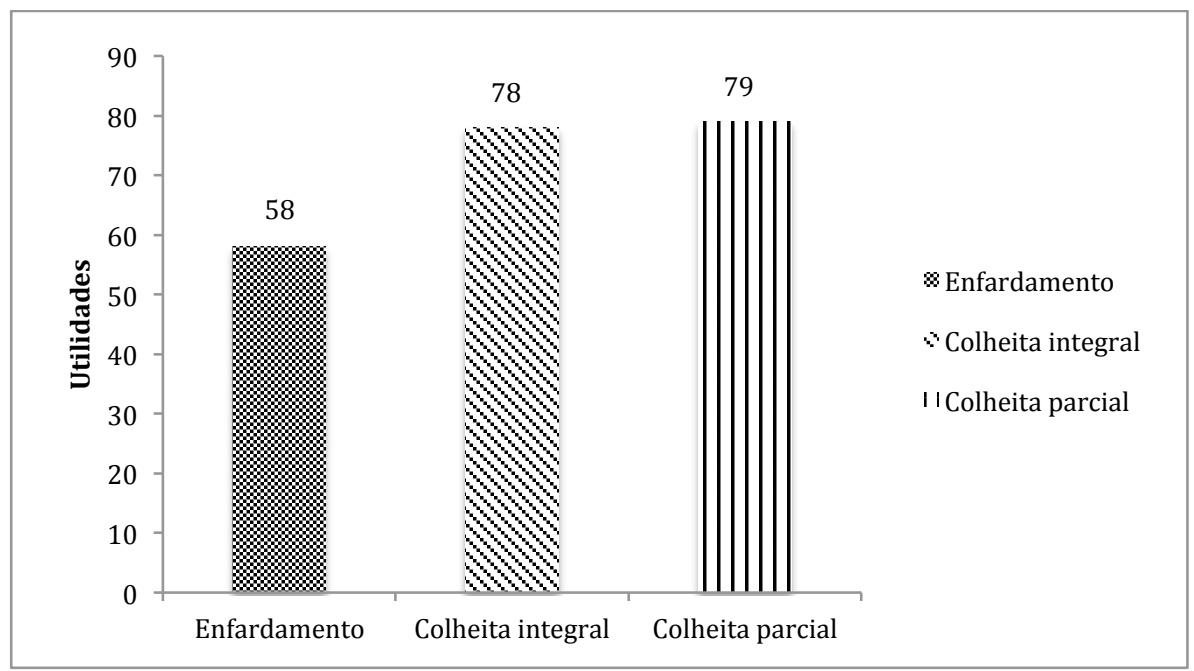

Figura 32: Avaliação do critério "custo de investimento" 
Em relação às "variáveis agroindustriais", os resultados mostram que a alternativa de enfardamento tem um melhor desempenho ao analisar o critério geral apresentado pela Figura 33 e os seus subcritérios, "variáveis agronômicas" e "variáveis industriais", apresentados pelas figuras 34 e 35, respectivamente. Um desempenho relativamente maior é observado na alternativa de colheita parcial em relação à alternativa de colheita integral, isso se deve ao subcritério "Eficiência de separação cana/palhiço" que tem uma utilidade maior para essa alternativa devido ao fato do palhiço recolhido de forma parcial possuir uma menor quantidade de impurezas. As Figuras 33, 34 e 35 apresentam o desempenho das alternativas de recolhimento considerando as variáveis agroindustriais.

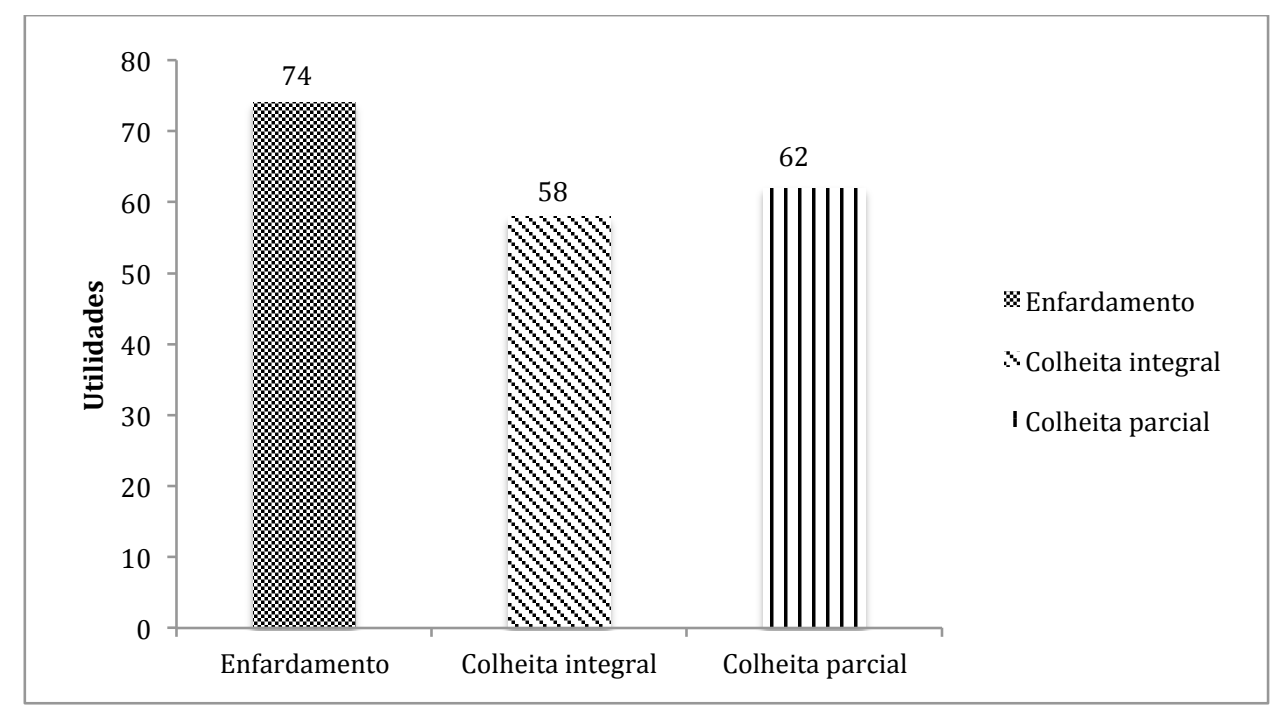

Figura 33: Avaliação do critério "variáveis agroindustriais"

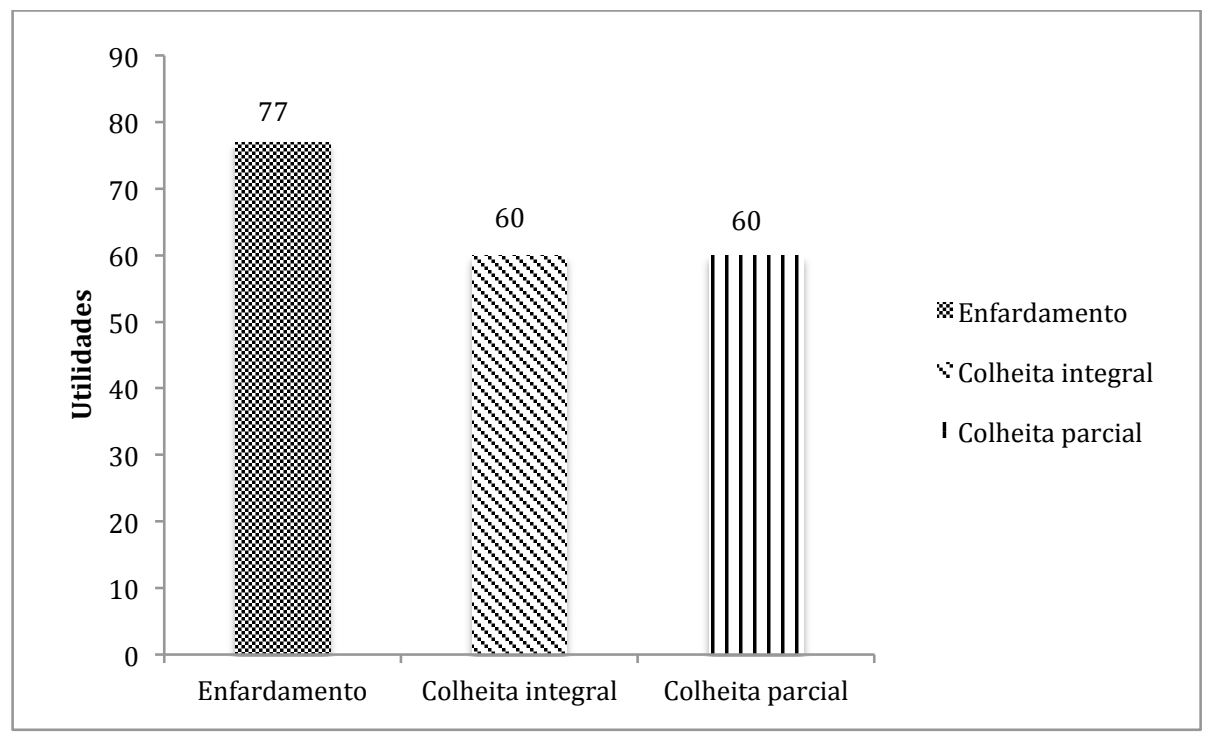

Figura 34: Avaliação do critério "variáveis agronômicas" 


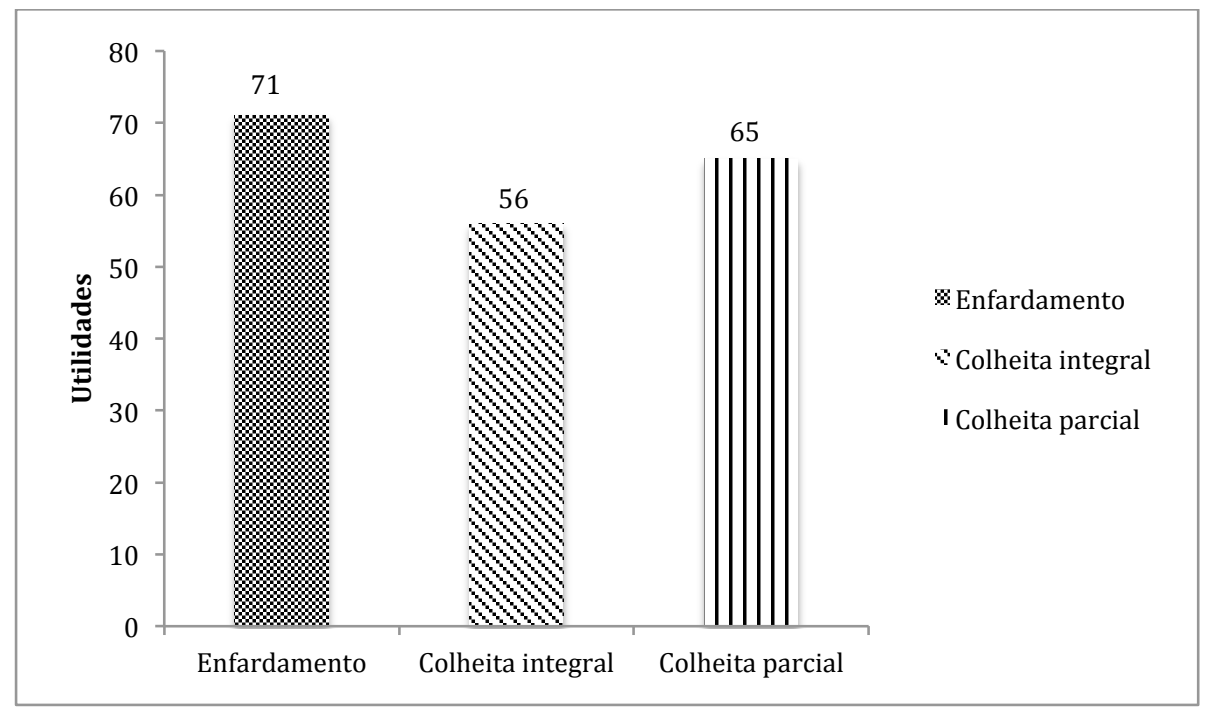

Figura 35: Avaliação do critério "variáveis industriais"

Ao se comparar os resultados do modelo para o recolhimento de palhiço considerando apenas o critério "valor esperado da receita", nota-se uma grande discrepância entre as alternativas de recolhimento. O enfardamento apresenta uma utilidade de $78 \%$, enquanto a colheita integral atinge $66 \%$ do objetivo geral e a colheita parcial apenas $22 \%$. Isso se deve ao fato da produtividade de energia produzida pelo enfardamento ser maior e também devido à quantidade de palhiço recolhido pela colheita parcial ser metade das outras alternativas. A Figura 36 mostra esses resultados.

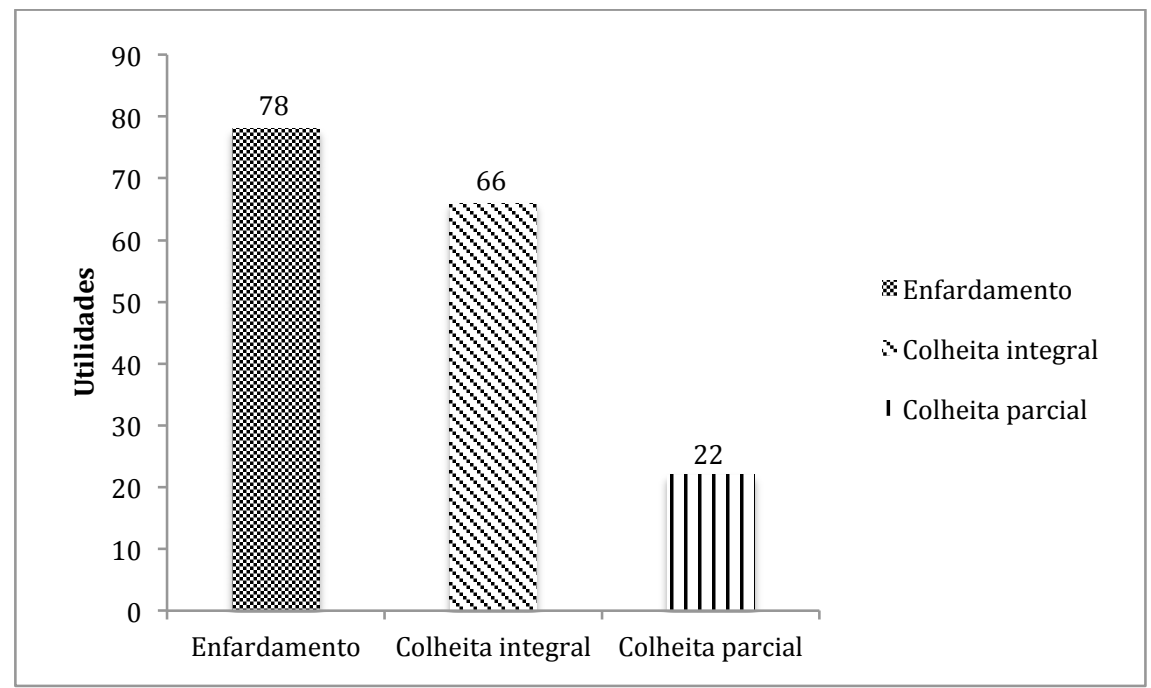

Figura 36: Avaliação do critério "valor esperado da receita"

\subsection{Análise de sensibilidade}


Esta etapa consiste em realizar variações nas preferências ou funções de utilidade dos critérios para analisar o desempenho da solução provisória. Caso a solução provisória continue sendo sugerida pelo modelo decisório, disse-se que a solução é robusta ou que tem alto grau de aderência. Consideram-se as seguintes análises de sensibilidade:

1) Variação na ponderação dos critérios;

2) Uso do método Rank Centroid (ROC) para ponderação dos pesos dos critérios;

3) Aplicação da análise de Monte Carlo para variação no preço da energia.

\subsubsection{Variação na ponderação dos critérios}

Para essa análise de sensibilidade, foi considerada a variação do peso de cada critério geral da estrutura hierárquica de objetivos frente a considerar os outros critérios como tendo peso iguais entre eles. Primeiro foi feita a oscilação do critério "variáveis agroindustriais", em seguida a variação do critério "custos" e depois essa alteração foi realizada para o critério de "valor esperado da receita".

A Figura 37 apresenta o comportamento das soluções frente a mudanças na preferência do critério de primeiro nível "variáveis agroindustriais". Nesta análise de sensibilidade considerou-se que os pesos dos outros critérios "custos" e "valor esperado da receita" ficassem iguais entre eles. Observa-se assim, que quando o peso do critério "variáveis agroindustriais" é 0 a alternativa sugerida é a de colheita integral e em segundo lugar a opção de enfardamento é a escolhida. Nota-se que a medida que o peso das "variáveis agroindustriais" aumenta até $20 \%$ a alternativa escolhida continua sendo a de colheita integral, mas quando peso das variáveis agroindustriais é maior que $20 \%$ a alternativa com maior preferência torna-se a de enfardamento. Isso significa que as alternativas de "colheita integral" e "enfardamento" apresentam todo o intervalo de preferência, mantendo-se assim as soluções sugeridas pelo modelo. 


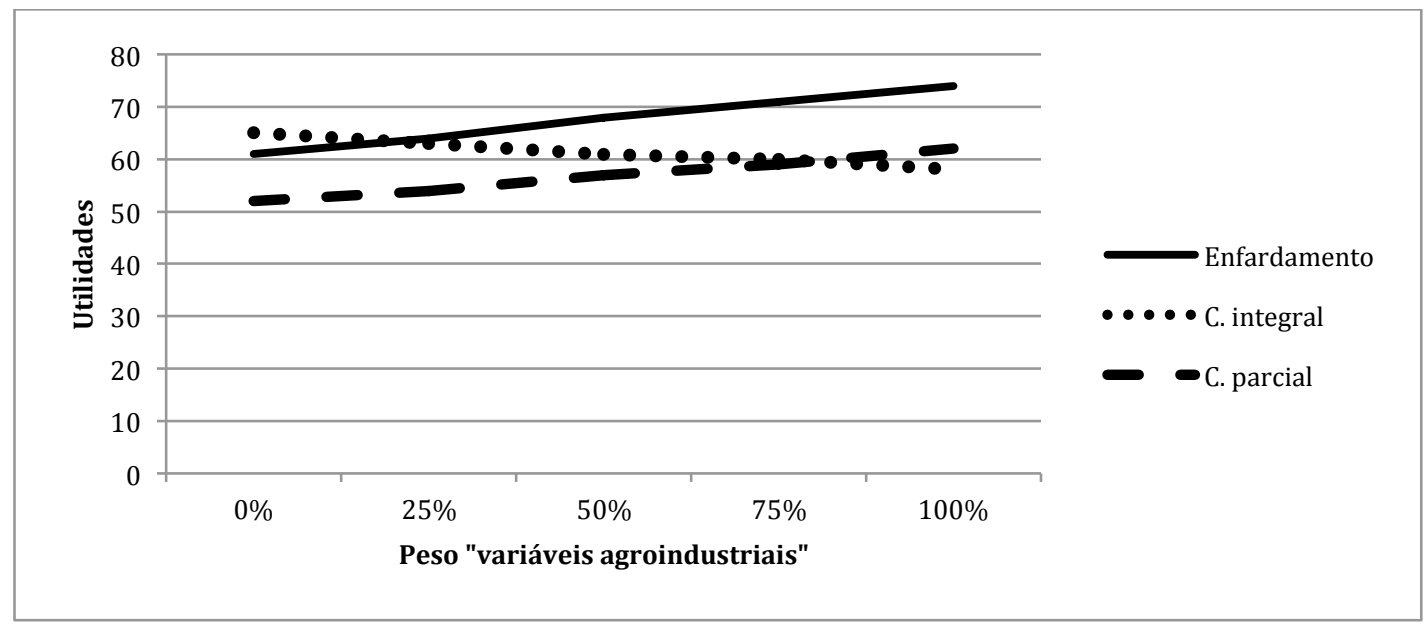

Figura 37: Anâlise de sensibilidade para variação dos pesos do critério "variáveis agroindustriais"

A Figura 38 apresenta a variação do critério "custos". Observa-se que quando o peso deste critério varia de 0 a $40 \%$ a solução escolhida é a de enfardamento e em segundo lugar a alternativa de colheita integral. Quando os "custos" tem uma variação entre 40\% e 53\% a opção sugerida pelo modelo é a de colheita integral. E, à medida que o peso dos "custos" varia de $53 \%$ a $100 \%$, a solução sugerida é a de colheita parcial. Isso acontece pois as alternativas de enfardamento e colheita integral têm um custo maior tanto de investimento quanto operacional.

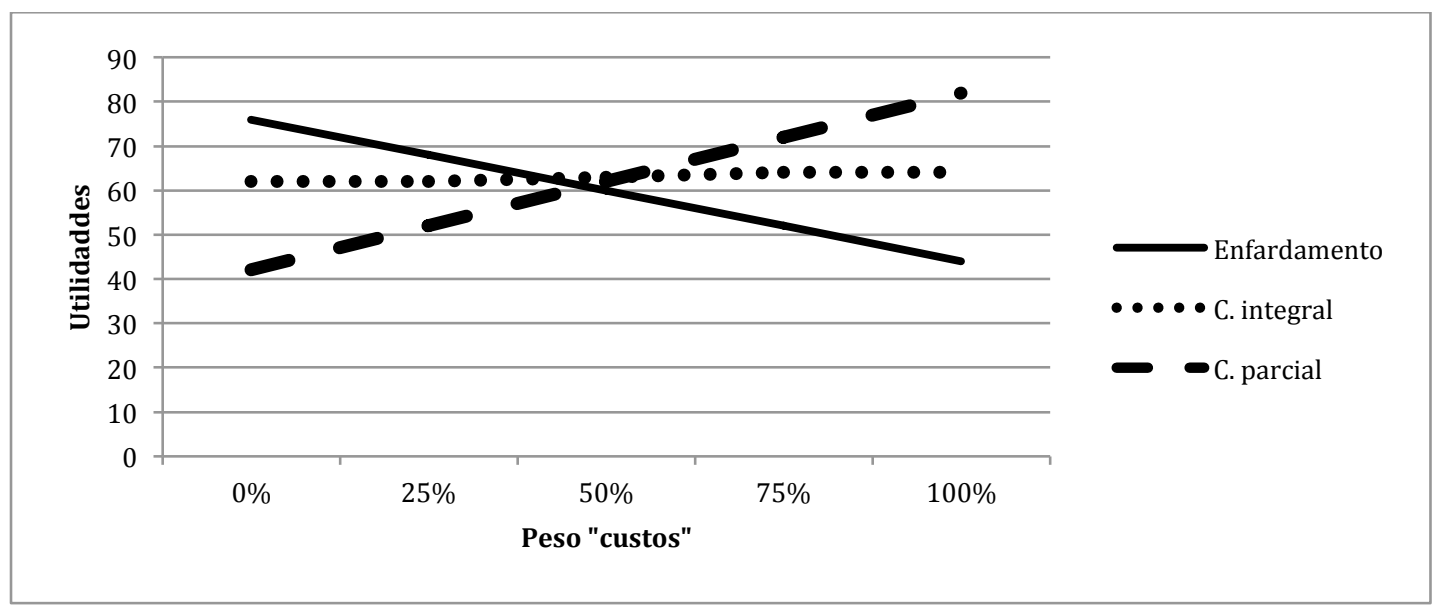

Figura 38: Análise de sensibilidade para variação dos pesos do critério "custos"

A Figura 39 apresenta o resultado da utilidade quando se varia o critério "valor esperado da receita" e mantém os valores das "variáveis agroindustriais" e "custos" iguais entre eles. Nota-se que a media que a utilidade do critério "valor esperado da receita" aumenta de $20 \%$ a $100 \%$, as alternativas de enfardamento e colheita integral se consolidam as 
preferidas, sendo que a utilidade do enfardamento é sempre maior para a variação deste critério, pois o enfardamento tem uma maior produtividade, gerando uma maior receita para um mesmo valor de preço de energia. Portanto, as alternativas provisórias "enfardamento" e "colheita integral" apresentam um amplo intervalo de preferência.

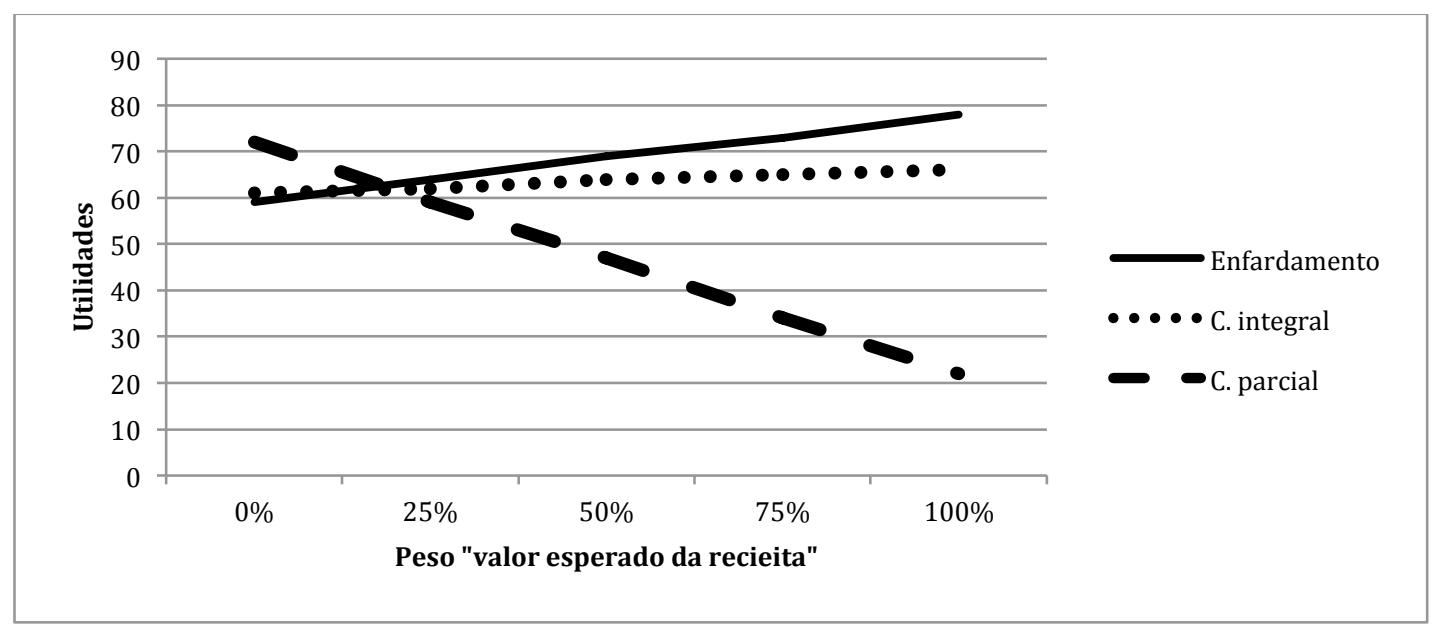

Figura 39: Análise de sensibilidade para variação dos pesos do critério "valor esperado da receita"

Assim, conclui-se que são necessárias grandes mudanças nas preferências dos decisores nos pesos dos critérios para tornar outra solução escolhida. Apenas na variação do critério "custos" as alternativas da solução provisória não foram escolhidas. Mesmo o critério “custos" tendo um peso considerável, ao levar em conta os outros critérios "variáveis agroindustriais" e "valor esperado da receita" com as preferências reais do decisor, as soluções sugeridas são o enfardamento e a colheita integral.

\subsubsection{Método Rank Centroid (ROC) para ponderação dos critérios}

A motivação pela implementação desta técnica é verificar se métodos mais simples para ponderação de critérios fornecem a mesma ordem de preferência entre as alternativas.

O Quadro 38 apresenta os valores calculados a partir da distribuição de pesos ROC, descrita na seção 3.2, e uma comparação com os pesos calculados pelo método SMART de ponderação. 
Quadro 38: Comparação dos pesos SMART e ROC

\begin{tabular}{|c|c|c|}
\hline Critérios & Pesos SMART & Pesos ROC \\
\hline Custos & 0,400 & 0,440 \\
\hline Custos de investimento & 0,400 & 0,2500 \\
\hline Enfardadora & 0,230 & 0,15767 \\
\hline Enleiradora & 0,077 & 0,0400 \\
\hline Transporte de fardos & 0,270 & 0,2567 \\
\hline Sistema de limpeza & 0,300 & 0,4567 \\
\hline Outros custos de investimentos & 0,123 & 0,0900 \\
\hline Custos operacionais & 0,600 & 0,7500 \\
\hline Combustível/Energia & 0,310 & 0,5208 \\
\hline Mão-de-obra & 0,230 & 0,1458 \\
\hline Manutenção & 0,300 & 0,2778 \\
\hline Outros custos operacionais & 0,160 & 0,0625 \\
\hline Variáveis agroindustriais & $\mathbf{0 , 2 0 0}$ & 0,1200 \\
\hline Variáveis agronômicas & 0,500 & 0,5000 \\
\hline Umidade & 0,440 & 0,2500 \\
\hline Qualidade do palhiço & 0,560 & 0,7500 \\
\hline Variáveis industriais & 0,500 & 0,5000 \\
\hline Produtividade de energia & 0,600 & 0,7500 \\
\hline Eficiência de separação & 0,400 & 0,2500 \\
\hline Valor esperado da receita & 0,400 & 0,4400 \\
\hline
\end{tabular}

No Quadro 38, pode-se notar que os decidores, no SMART, não têm uma preferência entre as variáveis agronômicas e industriais. Desse modo, diante da dificuldade de atribuir os pesos de 0,75 e 0,25 para esses critérios da forma em que se faz pelo método ROC quando se tem 2 critérios, foi utilizada uma fórmula adaptada do ROC para critérios de mesma ponderação.

Fórmula ROC :

$$
\mathrm{w} 1=(1+1 / 2+1 / 3+\ldots .1 / \mathrm{k}) / \mathrm{k}
$$

Fórmula adaptada para critérios de pesos iguais:

$$
\text { w1 e w2 }=(1 / 2+1 / 2) / 2=0,5
$$

O mesmo vale para os critérios gerais "valor esperado da receita" e "custos". Foi utilizada a fórmula do método ROC, porém com adaptação para critérios de mesma ponderação, como apresentado: 
Fórmula ROC :

$$
\mathrm{w} 1=(1+1 / 2+1 / 3+\ldots .1 / \mathrm{k}) / \mathrm{k}
$$

Fórmula adaptada para critérios de pesos iguais:

$$
\begin{aligned}
\text { w1 e w2 } & =(1 / 2+1 / 2+1 / 3) / 3=0,44 \\
\text { w3 } & =(0+0+1 / 3) / 3=0,12
\end{aligned}
$$

Dessa forma, foram estabelecidos os pesos 0,44 para "custos", 0,44 para o "valor esperado da receita" e 0,12 para as variáveis agroindustriais.

A Figura 40 apresenta o desempenho das alternativas em função dos pesos ROC.

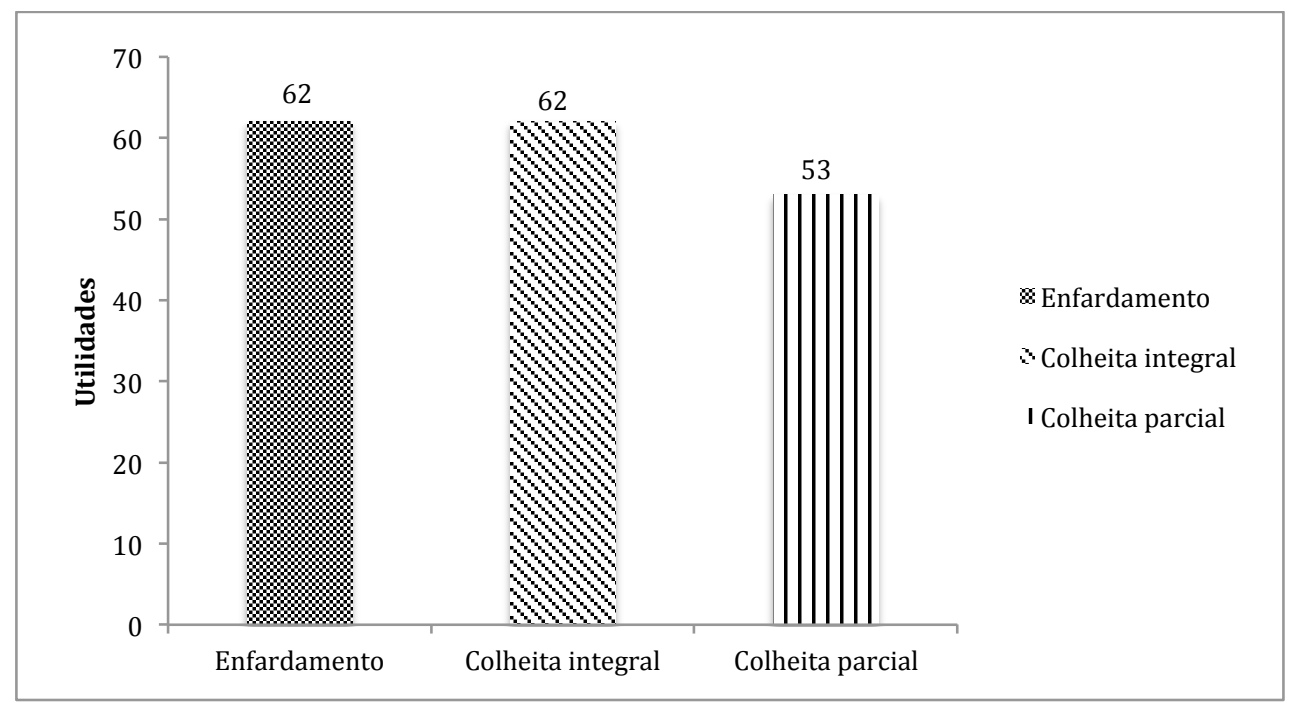

Figura 40: Desempenho das alternativas por meio dos pesos ROC

Observa-se que a solução de enfardamento e colheita integral continuam sendo as alternativas escolhidas pelo modelo com utilidades iguais de $62 \%$, ou seja atendem $62 \%$ dos objetivos. Com a utilização dos pesos ROC, o desempenho do enfardamento e colheita integral teve um decréscimo mínimo, passando de $64 \%$ na ferramenta SMART para $62 \%$ de utilidade utilizando a ponderação ROC. Já a alternativa de colheita parcial atingiu 53\% do objetivo geral, apenas um decréscimo de $1 \%$ do resultado obtido pelo método SMART de ponderação. Dessa forma, os resultados indicam uma ótima aderência da solução provisória frente a mudanças na técnica de ponderação utilizada, pois os pesos ROC forneceram uma classificação de alternativas similar à obtida com o SMART.

\subsubsection{Análise de Monte Carlo para variação no preço da energia}


O critério "valor esperado da receita" para avaliação das alternativas de recolhimento de palhiço utiliza informações futuras como a produção de excedente de energia e o preço da energia. Essas estimativas podem ser incorretas, e até certo ponto a imprecisão está principalmente na projeção econômica do preço da energia por ser muito volátil e depender de fatores externos. Neste caso, a análise de sensibilidade pelo método de Monte Carlo pode permitir conhecer qual a variação do "valor esperado da receita" e a alterntaiva de recolhimento de palhiço sugerida quando o parâmetro de preço da energia varia.

Para isso, é utilizado o histograma gerado com os dados históricos do PLD de 4 anos, e 200 dados aleatórios são gerados por meio do uso do software Microsoft Excel de acordo com a distribuição empírica. De modo geral, o histograma representa as probabilidades e valores remunerados da energia já observados. Assim, como já se possui o histórico de 4 anos do PLD, a distribuição empírica se mostra a mais adequada para a geração dos números aleatórios, pois reflete a porcentagem de vezes que se espera que um evento aleatório aconteça caso se repitam as mesmas condições históricas.

Definido o número de classes e seus intervalos, o Quadro 39 apresenta os limites inferiores e superiores de cada classe, o número de ocorrências e a frequência do PLD entre esses limites.

Quadro 39: Limites inferior e superior, número de ocorrências e frequência dos dados de PLD

\begin{tabular}{cccccccc}
\hline Classes & $\begin{array}{c}\text { Limite } \\
\text { inferior }\end{array}$ & $\begin{array}{c}\text { Limite } \\
\text { superior }\end{array}$ & Ocorrências & $\begin{array}{c}\text { Frequên- } \\
\text { cia }\end{array}$ & $\begin{array}{c}\text { Frequência } \\
\text { acumulada }\end{array}$ & $\begin{array}{c}\text { Limite } \\
\text { inferior }\end{array}$ & $\begin{array}{c}\text { Limite } \\
\text { superior }\end{array}$ \\
\hline 1 & 0 & 100 & 7 & $14,6 \%$ & $14,6 \%$ & 0 & $14,6 \%$ \\
2 & 100 & 200 & 10 & $20,8 \%$ & $35,4 \%$ & $14,6 \%$ & $35,4 \%$ \\
3 & 200 & 300 & 7 & $14,6 \%$ & $50 \%$ & $35,4 \%$ & $50 \%$ \\
4 & 300 & 400 & 8 & $16,7 \%$ & $66,7 \%$ & $50 \%$ & $66,7 \%$ \\
5 & 400 & 500 & 3 & $6,3 \%$ & $72,9 \%$ & $66,7 \%$ & $72,9 \%$ \\
6 & 500 & 600 & 4 & $8,3 \%$ & $81,3 \%$ & $72,9 \%$ & $81,3 \%$ \\
7 & 600 & 700 & 1 & $2,1 \%$ & $83,3 \%$ & $81,3 \%$ & $83,3 \%$ \\
8 & 700 & 800 & 3 & $6,3 \%$ & $89,6 \%$ & $83,3 \%$ & $89,6 \%$ \\
9 & 800 & 900 & 5 & $10,4 \%$ & $100,0 \%$ & $89,6 \%$ & $100,0 \%$ \\
\hline
\end{tabular}

Após a determinação desses parâmetros, são gerados 200 números aleatórios entre 0 e 1. Pelo Excel, cada número gerado é então nivelado em relação à sua posição entre o percentual dos limites inferior e superior e então é estabelecido o seu PLD correspondente.

A partir da simulação aleatória de preços da energia, é possível então calcular as receitas e, posteriormente, analisar as utilidades para cada opção de recolhimento de palhiço juntamente com os demais critérios. Assim, são obtidas as alternativas sugeridas pelo modelo genérico para cada preço de energia. O Apêndice E apresenta os cálculos dessas medidas. 
A partir da simulação de 200 números aleatórios do preço de energia, os resultados mostram que quando o preço da energia estiver até $\mathrm{R} \$ 162,00$ a alternativa escolhida é a de colheita parcial. Isso acontece pois preços de energia baixos refletem em uma receita menor e consequentemente em baixas utilidades para as alternativas (frequentemente utilidade 0). Dessa forma, uma menor interferência por parte do critério "valor esperado da receita" é verificada no modelo, assim os critérios de custo e variáveis agroindustriais, os quais a opção de colheita parcial tem um bom desempenho, apresentam uma força maior neste caso.

Para os preços de energia entre $\mathrm{R} \$ 163,00$ e $\mathrm{R} \$ 183,00$, o modelo considera uma utililidade semelhante para a colheita integral e parcial. Entre os preços de $\mathrm{R} \$ 184,00$ e $\mathrm{R} \$ 301,00$ a alternativa com maior preferência é a de colheita integral. Adicionalmente, se o preço da energia for de $\mathrm{R} \$ 302,00$ a $\mathrm{R} \$ 452,00$, as alternativas de recolhimento com fardos e colheita integral têm preferência no modelo. Mas se o PLD estiver entre R\$453,00 e R\$821 a alternativa escolhida é a de colheita integral. Isso ocorre pois preços de energia elevados geram altas receitas e refletem em utilidades muito significativas, apresentando muitas vezes utilidade máxima (100) tanto para o enfardamento quanto para a colheita integral. Desse modo, a solução é decidida pelo critério de "custo" que tem um grande peso e uma maior preferência pela colheita integral em relação ao enfardamento.

O modelo também apresenta que para preços de energia entre $\mathrm{R} \$ 822,00$ e $\mathrm{R} \$ 838,00$, tanto a colheita integral quanto a parcial são viáveis. Por outro lado, preços de energia extremamente elevados, ou seja, maiores que $\mathrm{R} \$ 839,00$ a solução com maior utilidade é a de colheita parcial. Isso é explicado pelo fato de que preços de energia muito altos refletem em receitas altas, e assim, as utilidades das três alternativas ficam elevadas, até mesmo da colheita parcial. Assim, uma menor interferência por parte do critério "valor esperado da receita" é verificada no modelo, pois as três alternativas passam a ter utilidades muito próximas, ou até semelhantes, assim os critérios de custo e variáveis agroindustriais, os quais a opção de colheita parcial tem um bom desempenho, apresentam uma força maior neste caso. O Quadro 40 apresenta as relações descritas acima: 
Quadro 40: Faixa de preço e alternativa sugerida

\begin{tabular}{cc}
\hline Faixa de preços (R\$) & Alternativa sugerida \\
\hline$<162,00$ & Colheita parcial \\
163,00 a 183,00 & Colheita parcial e Colheita integral \\
184,00 a 301,00 & Colheita integral \\
302,00 a 452,00 & Enfardamento e Colheita integral \\
453,00 a 821,00 & Colheita integral \\
822,00 a 838,00 & Colheita integral e Colheita parcial \\
$>839,00$ & Colheita parcial \\
\hline
\end{tabular}

Adicionalmente, em $41 \%$ das simulações feitas com o preço da energia a alternativa sugerida foi a de colheita integral e $30 \%$ a de colheita parcial. Além disso, em $21,5 \%$ das tentativas, a utilidade do enfardamento ou de colheita integral são sugeridas. E em 7,5\% das simulações as alternativas de colheita integral e parcial também têm a mesma valoração. A Figura 41 apresenta a frequência das alternativas de recolhimento de palhiço sugeridas pela análise de Monte Carlo.

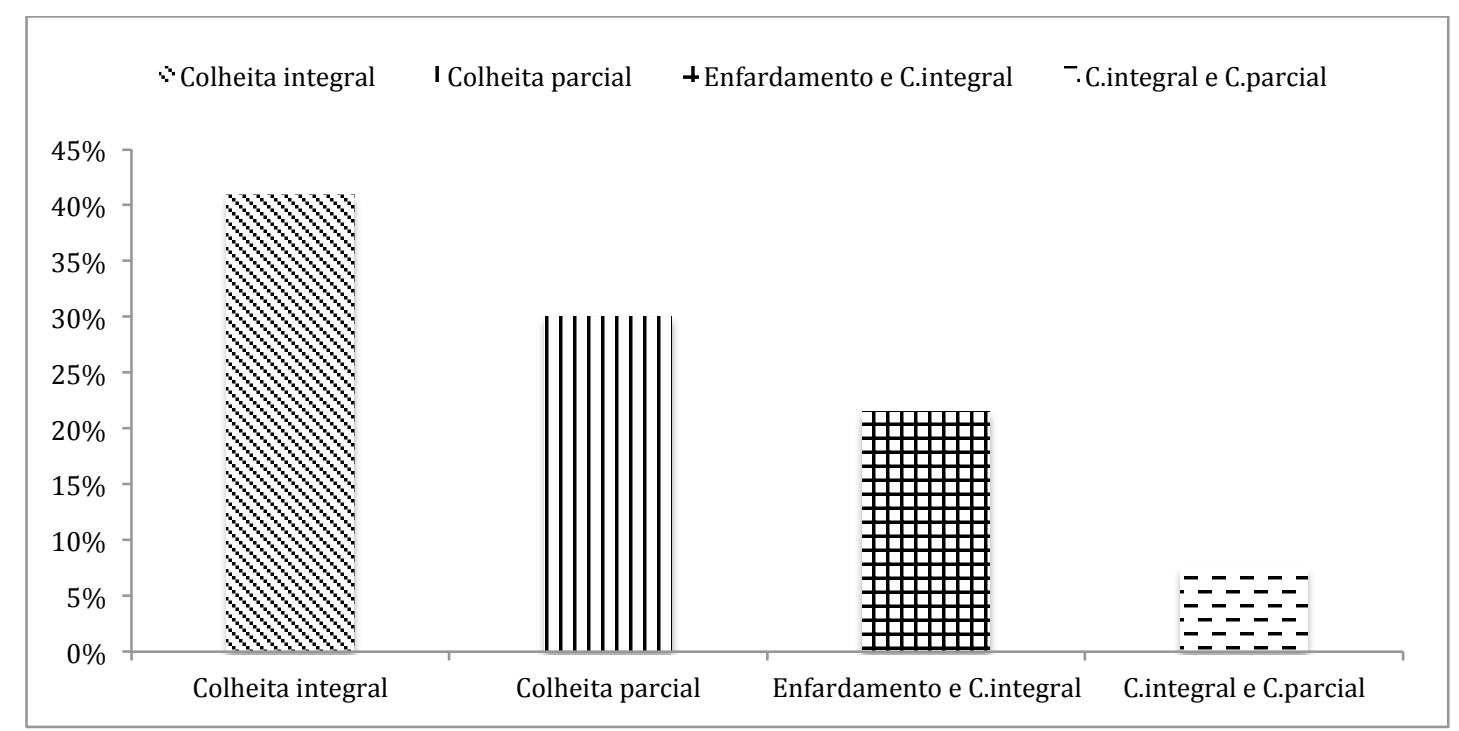

Figura 41: Frequência das alternativas de recolhimento sugeridas pela análise de Monte Carlo

Dessa forma, a solução provisória de colheita integral continua sendo sugerida pela análise de Monte Carlo. Por outro lado, para uma menor quantidade de preços de energia a alternativa de enfardamento foi escolhida. Dessa forma, os resultados indicam uma boa aderência de uma das alternativas sugeridas na solução provisória frente às simulações realizadas com o preço da energia, aspecto importante para a decisão de escolha da alternativa 
de recolhimento. Conclui-se assim, que ao realizar grandes variações no preço da energia, a alternativa escolhida é a de colheita integral.

\subsection{Determinação da alternativa com melhor desempenho}

Após as análises de sensibilidade, a alternativa provisória de "colheita integral" pode se tornar a solução final escolhida.

Considerando apenas os resultados da primeira análise de sensibilidade, as soluções de colheita integral e enfardamento são factíveis, pois é possível concluir que grandes variações nas ponderações dos critérios são necessárias para gerar uma mudança na solução do modelo, o que evidencia a robustez da abordagem proposta. Para a técnica de ponderação de critérios utilizando o método ROC, as soluções provisórias de colheita integral e enfardamento também apresentaram um bom comportamento, visto que o modelo recomenda as duas soluções e as indica como tendo o mesmo potencial de escolha. No entanto, essas análises consideram os preços da energia ponderados pelas respectivas probabilidades, sendo assim um valor fixo e determinístico. Logo, o modelo gera a solução para esse valor.

Já a simulação de Monte Carlo considera o "valor esperado da receita" para cada preço de energia considerado. Nesta análise os resultados apresentam que para $41 \%$ dos preços de energia simulados, a solução provisária de colheita integral é a sugerida. Assim, ao se considerar o caráter estocástico do preço da energia, a alternativa de colheita integral mostrou-se mais interessante. 


\section{CONCLUSÃO}

Esta pesquisa teve como objetivo propor uma metodologia para abordar o problema do recolhimento de palhiço para a cogeração de energia onde as alternativas de colheita, enfardamento, colheita integral e colheita parcial estão disponíveis. A metodologia de análise de decisão multicritério, incorporando critérios construídos (no caso o valor esperado da receita) por meio de uma árvore baseada em valor e probabilidades, bem como a análise de simulação de Monte Carlo para escolha aleatória dos preços de mercado, é a principal contribuição desta metodologia.

Diferente de outras abordagens, este trabalho tem foco na integração de critérios qualitativos e quantitativos, que não estão relacionados somente com o custo e receita do recolhimento e cogeração de energia, mas também com fatores agroindustriais responsáveis pelo bom desempenho da biomassa para a cogeração de energia elétrica. A produção de excedente de energia por meio do palhiço é uma alternativa para as usinas aqui analisadas. Portanto, a metodologia proposta também apresenta uma contribuição para o setor, à medida que foi validada por meio da aplicação do modelo utilizando dados de usinas com moagem de aproximadamente 3 milhões de toneladas de cana por safra. Neste sentido, os resultados desta pesquisa podem apoiar a tomada de decisão sobre as alternativas de recolhimento de palhiço. $\mathrm{O}$ modelo pode ser utilizado por qualquer usina apenas com adaptações referentes às suas preferências e atualizações em relação aos valores. Os decisores podem também formular cenários de interesse e comparar o seus resultados.

Outra contribuição se remete ao modelo de decisão, o qual abordou características interessantes à literatura dos problemas de recolhimento de palhiço. O modelo considerou usinas onde os modos de recolhimento de palhiço foram aprofundados para analisar os tradeoffs existentes entre custo, receita e variáveis agroindustriais, fatores analisados conjuntamente que não foram objeto de estudos em trabalhos prévios. Neste sentido, os critérios levantados nesta dissertação são outra importante contribuição da pesquisa, pois colabora para a organização da literatura sobre os fatores que influenciam à tomada de decisão da escolha entre as alternativa de recolhimento de palhiço.

A metodologia foi fundamentada nas funções de utilidade da teoria da utilidade, cujas propriedades permitem incorporar as preferências e atitude ao risco do decisor para avaliar o desempenho das alternativas. Para isso, um conjunto de critérios relevantes para o recolhimento do palhiço e cogeração de energia foi escolhido, que quando julgados pelos 
decisores, evidenciaram as diferenças entre os modos de recolhimento por enfardamento, colheita integral e parcial.

Para definir as preferências entre os critérios apontados, o método de ponderação SMART foi utilizado devido a sua aceitação e amplo uso na literatura e na prática. Esse método demonstrou ser útil para a construção da hierarquia.

Em relação à aplicação do modelo, os julgamentos evidenciaram a preferência dos decisores pelo custo e valor esperado da receita em relação às variáveis agroindustriais. Segundo esta ponderação agregada, um baixo custo geral representou um bom desempenho do sistema em pelo menos $40 \%$ das vezes, sendo que a receita também representou $40 \%$ desse desempenho. Por outro lado, as variáveis agroindusriais explicaram $20 \%$ do desempenho do sistema. Isto é um interessante aspecto que permite concluir que a escolha não é motivada unicamente por critérios econômicos, mas sim pela diversidade e combinação de todos estes fatores.

As alternativas de recolhimento sugeridas pelo modelo multicritério provisioramente foram a colheita integral e o enfardamento. Análises de sensibilidade permitiram conferir o bom desempenho das soluções sugeridas frente a outros cenários de interesse propostos, como a variação no peso dos critérios, a ponderação de critérios pelo método ROC. Porém, ao realizar a análise de sensibilidade de simulação de Monte Carlo com inúmeras simulações do preço da energia, a alternativa recomendada pelo modelo foi a de colheita integral, visto que para $41 \%$ dos preços de energia simulados, essa alternativa apresentou um melhor desempenho. Neste sentido, é interessante notar que a solução sugerida pela metodologia não é a solução ótima em custo visível. Por outro lado, espera-se que esta forneça o melhor desempenho geral atendendo os critérios da estrutura hierárquica de decisão. Além de um custo aceitável e um alto valor esperado da receita, esta solução satisfaz outras necessidades em comparação às outras soluções, isto é uma importante contribuição, especialmente nos casos onde muitos objetivos conflitantes aparecem. Vale ressaltar que a solução sugerida também tem a característica de manter um bom desempenho frente aos vários cenários propostos.

Adicionalmente algumas limitações da abordagem proposta também são apresentadas como segue: tempo necessário para efetuar todas as etapas da metodologia, pois os problemas operacionais requerem respostas rápidas para responder a um planejamento em curto prazo; mas muitas vezes as entrevistas e coletas de dados são atividades com retorno lento. Outra limitação da pesquisa tange à subjetividade inerente aos decisores quanto à escolha, ponderação dos critérios e à precisão dos dados fornecidos, porém pelo fato de tornar suas 
preferências explicitas, os decisores são mais conscientes das suas escolhas e informações oferecidas. $\mathrm{O}$ estudo requer um amplo envolvimento com os profissionais da empresa, pois os dados não são os únicos recursos necessários. Os decisores devem estar diretamente relacionados ao problema, pois são eles quem priorizam os critérios que influenciam na escolha final. A limitação resulta no caso em que estes decisores chaves não estejam disponíveis para oferecer seus julgamentos. Adicionalmente, os dados não foram coletados de uma só usina, sendo complementados à medida que foram necessários para a construção do modelo genérico. Isto se deve ao fato de que nem todas as usinas têm todos os dados, ou não operam com as mesmas alternativas ou até não levam em consideração todos os critérios. No entanto, entende-se que, por serem usinas que mantêm o mesmo padrão de operação (capacidade de geração de energia, volume processado/dia, entre outras características comuns apresentadas no Quadro 10) podem usufruir do modelo e realizar cenários para avaliação de prospecção na produção de energia, seja por meio do uso de parte dos critérios e ou alternativas. Pode-se até construir outros critérios e também outras alternativas.

Uma possível limitação ou como sugestão de trabalhos futuros é o uso combinado de alternativas. Pode ser que em determinadas áreas mais longe opte-se pela colheita integral com enfardamenteo enquanto áreas mais perto optam pela colheita integral ou parcial devido aos custos de transporte.

Como pesquisas futuras, convém ser analisados pelas usinas problemas estratégicos e logísticos como a seleção das fazendas fornecedoras de palhiço que otimizaria o processo de recolhimento. Também seria interessante realizar um desdobramento da abordagem proposta referente à implementação sobre outros problemas envolvendo a cogeração de energia a partir do palhiço após o seu recolhimento, como estoque de palhiço e os sistemas de cogeração adequados para essa biomassa com objetivo de verificar o seu desempenho.

Conforme a sua importância, convém analisar também o impacto de outros métodos de ponderação de critérios, bem como estudar a influência das técnicas de agrupamento de ponderações, onde são modeladas as opiniões de vários decisores, pois nos grandes e importantes problemas mais de um decisor costuma estar envolvido. 


\section{REFERÊNCIAS BIBLIOGRÁFICAS}

ABRÃO J. S. Níveis de Palhadas e Preparos do Solo em Cultivos de Cana-de-Açúcar: Impacto Sobre a Fauna Edáfica e Epigeica. UEMS, Aquidauana, 2012.

ABREU, W. S. D. Modelagem e previsão de preços à vista de energia elétrica e aplicações no contexto de investimentos sob incerteza. Dissertação de Mestrado. Pontifícia Universidade Católica do Rio de Janeiro, 2012.

AGUEZZOUL, A. Third-party logistics selection problem : A literature review on criteria and methods. Omega, 2014.

ALEXANDER, A, Sugarcane physiology, a Comprehensive Study of the Saccharum Sourceto-Sink System. University of Puerto Rico publishing house, 1973.

AVAREZ, I.A.; CASTRO, P.R.C. Crescimento da parte aérea de cana crua e queimada. Scientia Agricola. Piracicaba, SP, v.56, p.1069-1079, 1999.

ANDREOLLI, C. Convergência de Agricultura e Energia: I. Produção de Biomassa Celulósica para Biocombustíveis e Eletricidade. Economia \& Energia, 2008.

AUDE, M. I. S.; MARCHEZAN, E.; DARIVA, T.; PIGNATARO, I. H. B. Manejo do palhiço da cana-de-açúcar: 1. Efeito na produção de colmos industrializáveis e outras características agronômicas. Ciência Rural. Santa Maria, v. 23, n. 3, p. 281-286, 1993.

AZEVEDO, B. B., ALMEIDA, R. P., \& SILVA, V. V. M. Aplicação do método árvore de decisão para apreciação de alternativas de investimento. XXXIII Encontro Nacional de Engenharia de Produção, 2013.

BANCO NACIONAL DE DESENVOLVIMENTO ECONÔMICO E SOCIAL- BNDES. Bioetanol de cana-de-açúcar - Energia para o desenvolvimento sustentável. Rio de Janeiro, 2008. Disponível em:< http://www.bioetanoldecana.org/> Acesso em: setembro de 2016.

BLANCO-CANQUI H. Crop residue removal for bioenergy reduces soil carbon pools: how can we offset carbon losses? BioEnergy Research, 2012

BERNARDES, J. A.; ARRUZZO, R. C. Expansão do setor sucroenergético e a história dos lugares: A questão territorial dos Guarani e Kaiowá em Mato Grosso do Sul. Revista da ANPEGE, 2016.

BELTON, V.; STEWART, T. J. Multiple Criteria Decision Analysis: an Integrated Approach. New York: Springer, 2002.

BRADSTTAW, J. M.; BOOSE, J. H. Decision analysis techniques for knowledge acquisition: combining information and preferences using Aquinas and Axotl. Int. J. Man-Machine Studies, v. 32, p. 121-186, 1990. 
BREALEY, R. A., MYERS, S. C., ALLEN, F., \& MOHANTY, P. Principles of corporate finance. Tata McGraw-Hill Education, 2012.

CARDOSO, T. F., NEVES, J. M., CHAGAS, M. F. Lei da Balança. Uma avaliação nos custos de produção de cana-de-açúcar de recolhimento de palha. Boletim CTBE, 2017.

CARVALHO, J. L. N., NOGUEIROL, R. C., MENANDRO, L. M. S., BORDONAL, R. D. O., BORGES, C. D., CANTARELlA, H., \& FRANCO, H. C. J. Agronomic and environmental implications of sugarcane straw removal: a major review. GCB Bioenergy, 2016.

CASAROTTO FILHO, N.; KOPITTKE, B. H. Análise de investimentos: matemática financeira, engenharia econômica, tomada de decisão, estratégia empresarial. 11. ed, São Paulo: Atlas, 2010.

CAMPOS L. H. F., CARVALHO S. J. P., CHRISTOFFOLETI P. J., FORTES C, SILVA J. S. Sistemas de manejo da palhada influenciam acumulo de biomassa e produtividade da canade-açúcar (var. RB855453). Acta Scientarum Agronomy, 2010.

COBULOGLU, H. I., \& BÜYÜKTAHTAKıN, E. A stochastic multi-criteria decision analysis for sustainable biomass crop selection. Expert Systems with Applications, 2015.

CONAB. Companhia Nacional de Abastecimento. Acompanhamento da safra brasileira: canade-açúcar - Safra 2016/2017, primeiro levantamento, abril de 2016. Disponível em: $<$ http://www.conab.gov.br $>$. Acesso em: outubro de 2017.

CORRÊA NETO, V.; RAMON, D. Análises de opções tecnológicas para projetos de cogeração no setor sucroalcooleiro. Brasília: SETAP Sustainble Energy Techonology Assistance Program, 2002.

CORREAA NETO, V. Análise de viabilidade da cogeração de energia elétrica em ciclo combinado com gaseificação de biomassa de cana- de-açúcar e gás natural. Rio de Janeiro. Dissertação (Mestrado) - Programa de Pós-Graduação em Planejamento Energético, Universi- dade Federal do Rio de Janeiro, 2001.

CENTRO DE TECNOLOGIA CANAVIEIRA - CTC - $14^{\circ}$ Seminário Internacional em Logística Agroindustrial - ESALQ-LOG Aproveitamento da palha de cana, 2017.

DE FIGUEIREDO E. B., PANOSSO A. R., REICOSKY D. C., LA SCALA N. Short-term $\mathrm{CO}_{2}-\mathrm{C}$ emissions from soil prior to sugarcane (Saccharum spp.) replanting in southern Brazil.

Global Change Biology Bioenergy, 2015.

DIAS, M. O. S.; JUNQUEIRA, T. L.; CAVALETT, O.; PAVANELLO, L. G.; CUNHA, M. P.; JESUS, C. D. F.; MACIEL FILHO, R.; BONOMI, A. Biorefineries for the production of first and second generation ethanol and electricity from sugarcane. Applied Energy Journal, 2013.

EDWARDS, W.; BARRON, F. SMARTS and SMARTER: Improved Simple Methods for Multiattribute Utility Measurement. Organizational Behavior and Human Decision Processes, 1994. 
ENSSLIN, L.; MONTIBELLER NETO, G. e NORONHA, S.M.D. Apoio à Decisão: Metodologias para Estruturação de Problemas e Avaliação Multicritério de Alternativas. 1. ed. Insular. Florianópolis, 2001.

EPE - Empresa de Pesquisa Energética, 2016. Balanço energético 2017, ano base 2016. Disponível em: <https://ben.epe.gov.br/>. Acesso em: janeiro de 2017.

EPE - Empresa de Pesquisa Energética, 2013. Balanço energético 2013, ano base 2012. Disponível em: <https://ben.epe.gov.br/>. Acesso em: janeiro de 2017.

ELLIS, J., W. H., CORFEE-MORLOT, J., GAGNON-LEBRUN, F. CDM: Taking stock and looking forward. Energy policy, 2007.

FIGUEIRA, J.; GRECO, S.; EHRGOTT, M. ET AL. Multiple Criteria Decision Analysis: State of the Art Surveys. Boston: Springer, 2005.

FRANCO A. L. C. , BARTZ M. L. C., CHERUBIN M. R. Loss of soil (macro)fauna due to the expansion of Brazilian sugarcane acreage. Science of the Total Environment, 2016.

FLORENTINO, H. O.; LIMA, A. D.; CARVALHO, L. R.; BALBO, A. R.; HOMEM, T. P. D. Multiobjective 0-1 integer programming for the use of sugarcane residual biomass in energy cogeneration. International transactions in operational research, 2011.

FLORENTINO, H., \& SPADOTTO, A. O problema da mochila no carregamento do palhiço de cana-de-açúcar. Congresso nacional de matemática aplicada e computacional, XXIX, 2006.

FURLAN, F. F.; TONON FILHO, R.; PINTO, F. H. P. B.; COSTA, C. B. B.; CRUZ, A. J. G.; GIORDANO, R. L. C.; GIORDANO, R. C. Bioelectricity versus bioethanol from sugarcane bagasse: is it worth being flexible? Biotechnology for biofuls, 2013.

FURLANI NETO, V. L.; RIPOLI, T. C. C.; VILLA NOVA, N. A. Biomassa de canadeaçúca: energia contida no palhiço remanescente de colheita mecânica. STAB, Açúcar, Álcool e Subprodutos, Piracicaba, v. 15, n. 4, p. 24-27, mar/abr, 1997.

GALESNE, A.; FENSTERSEIFER, J. E.; LAMB, R. Decisões de investimentos da empresa. São Paulo: Atlas, 1999.

GERMEK, H. A. Análise de decisão sobre o aproveitamento do palhiço da cana-deaçúcar, posto na unidade industrial, para fins de cogeração. Tese de doutorado, UNESP, Botucatu, 2005.

GERMEK, H. A., PATROCÍNIO, A. B., SILVA, F. C., SiMON, E. J., \& RÍPOLI, T. C. Analysis decision about the sugarcane straw recovery for cogeneration in unity operation industry. Bioenergia em Revista: Diálogos, 2014.

GIGERENZER, G.; TODD, P. M. Simple heuristics that make us smart. Oxford: Oxford University Press, 1999. 
GIL, A. C. Metodologia científica. São Paulo, 3, 2002

GOMES, L.; ARAYA, M.; CARIGNANO, C. Tomada de decisões em cenários complexos: introdução aos métodos discretos do apoio multicritério à decisão. São Paulo: Pioneira Thomson Learning, 2004.

GOMES, L.; GOMES, C.; ALMEIDA, A. Tomada de decisão gerencial: enfoque multicritério. São Paulo: Atlas, 2002.

GONÇALVES, C. G. Responsabilidade socioambiental como fator de competitividade: estudo de caso em uma empresa do setor sucroalcooleiro no Brasil. Dissertação de mestrado, FEUC, 2013.

GOODWIN, P.; WRIGHT, G. Decision Analysis for Management Judgment. 3. ed. England: John Wiley \& Sons, 2005.

HAMES B. R., THOMAS S. R., SLUITER A. D., ROTH C. J., TEMPLETON D. W. Rapid biomass analisis. Applied Biochemstry and Biotechnology, 2003.

HASSUANI, S. J., LEAL, M. R. L. V., \& MACEDO, I. Biomass power generation. Sugar cane bagasse and trash.Programa das Nacoes Unidas para o Desenvolvimento and Centro de Technologia Canavieriva, Piracicaba, Brazil, 2005.

HILL, J.; NELSON, E.; TILMAN, D.; POLASKY, S.; TIFFANY, D. Environmental, economic, and energetic costs and benefits of biodiesel and ethanol biofuels. Proceedings of the National Academy of Science, 2006.

HOWARD, R. A.; MATHESON, J. E. Readings on the Principles and Applications of Decision Analysis. Menlo Park, California: Strategy Decisions Group, 1984.

INNOCENTE, A. Cogeração a partir da biomassa residual de cana-de-açúcar- Estudo de caso. Dissertação de mestrado. Faculdade de Ciências Agronômicas da UNESP. Botucatu, 2011.

JOHNSON, J.M.F.; COLEMAN, M.D.; GESH, R.; JARADAT, A.; MITCHELL, R.; REICOSKY, D.; WILHELM, W.W. Biomass-bioenergy crops in the United States: a changing paradigm. The Americas Journal of Plant Science and Biotechnology, Kagawaken, v.1, n.1, p.1-28, 2007.

KEENEY, R. L. Value-focused thinking: Identifying decision opportunities and creating alternatives. European Journal of Operational Research, v. 92, p. 537-549, 1996.

KEENEY, R. L.; RAIFFA, H. Decisions With Multiple Objectives; Preferences and Value Tradeoffs. New York: Wiley, 1976.

KEENEY, R. L.; WINTERFELDT, D. Practical Value Models. published articles \& Paper, v. 36, 2009.

KLIEMANN NETO, F. J et al. A Gestão de riscos como ferramenta para aumento da competitividade das empresas. Tópicos emergentes e desafios mercadológicos em Engenharia 
de Produção: casos, experiências e proposições. v. 4, XXX Encontro Nacional de Engenharia de Produção, São Carlos: ABEPRO, 2010.

KUVA, M. A., FERRAUdO, A. S., PITElli, R. A., ALVES, P. L. C. A., \& SALGADO, T. P. Padrões de infestação de comunidades de plantas daninhas no agroecossistema de canacrua. Planta Daninha, 2008.

KHATIWADA, D.; LEDUC, S.; SILVEIRA, S. MCCALLUM, I. Optimizing ethanol and bioelectricity production in sugarcane biorefineries in Brazil. Renewable Energy Journal, 2015.

LINERO, F. A. B. Importância da palha na geração de excedentes de eletricidade e produção de etanol 2G. Ribeirão Preto: SINATUB, 2013.

LISKA, A. J, YANG H. , MILNER M . Biofuels from crop residue can reduce soil carbon and increase CO2 emissions. Nature Climate Change, 4, 398-401, 2014.

LOKEN, E.; BOTTERUD, A.; HOLEN, A. T. Use of the equivalent attribute technique in multi-criteria planning of local energy systems.European Journal of Operational Research, 2009.

MACEDO, I. C., SEABRA, J. E., \& SILVA, J. E. Green house gases emissions in the production and use of ethanol from sugarcane in Brazil: the 2005/2006 averages and a prediction for 2020. Biomass and bioenergy, 2008.

MACEDO, N.M.; BOTELHO, P.S.M.; CAMPOS, M.B.S. Controle químico de cigarinhadaraiz em cana-de-açúcar e impacto sobre a população de artrópodes.STAB, Açúcar, Álcool e Subprodutos, v.21, p.30-33, 2003.

MAIA, V. M., MEIRELES, B. L., KLÖTZLE, M. C., PINTO, A. C. F., \& GOMES, L. L. Água: Único Fator a Influenciar o Preço da Energia no Mercado Spot?. Sociedade, contabilidade e gestão, 2016.

MARTINS FILHO, M. V, LICCIOTI T. T, PEREIRA G. T, MARQUES JUNIOR J., SANCHES R. B. Perdas de solo e nutrientes por erosão num argissolo com resíduos vegetais de cana- de-açúcar. Engenharia Agrícola, 2009.

MICHELAZZO, M. B., BRAUNBECK A. O. Análise de seis sistemas de recolhimento do palhiço na colheita mecânica da cana-de-açúcar. Revista Brasileira de Engenharia Agrícola e Ambiental, 2008

MICHAILOS, S., PARKER, D., \& WEBB, C. A multicriteria comparison of utilizing sugar cane bagasse for methanol to gasoline and butanol production.Biomass and Bioenergy, 2016.

MORAES, L. M., BACCHI, M. R. P. Etanol, do início às fases atuais de produção. Revista de Política Agrícola, 2014.

MOTA, C. M. D. M. Modelagem multicritério em gerenciamento de projetos. Tese de doutorado. UFPE. Recife, 2005. 
OLIVEIRA, M. G. Potencial de produção de energia elétrica em 10 usinas no setor sucroalcooleiro no estado do Paraná na safra 2012/2013. Tese de conclusão de curso, Universidade Tecnológica Federal do Paraná, 2014.

OZERNOY, V. M. Choosing the Best Multiple Criteria Decision-Making Method. INFOR, v. 30, n. 2, p. 159-171, 1992.

PAIXÃO, M. Os Vinte Anos do PROÁlCOOL: As Controvérsias de um Programa Energético de Biomassa. Série "Brasil: Sustentabilidade e Democracia", São Paulo, Brasil, 1997

PELLEGRINI, M. C. Inserção de centrais cogeradoras a bagaço de cana no parque energético do estado de São Paulo: exemplos de aplicações de metodologia para análise dos aspectos locacionais e de integração energética.Dissertação Mestrado em EnergiaUniversidade de São Paulo, São Paulo, 2002.

PIEROSSI, M.A.; FAGUNDES, S.A. Enfardamento da Palha. Cana-de-açúcar: do plantio à colheita. Viçosa: UFV, 2013.

PRADO, T. G. F. Externalidades do ciclo produtivo da cana-de-açúcar com ênfase na produção de energia elétrica. Dissertação de mestrado.Universidade de São Paulo, 2007.

QUINLAN, J. R., \& RIVEST, R. L. Inferring decision trees using the minimum description lenght principle. Information and computation, 1989.

RAVANELI G. C., GARCIA D. B., MADALENO L. L., MUTTON M. A., STUPIELlO J. P., Mutton M.J.R. Spittlebug impacts on sugarcane quality and ethanol production. Pesquisa Agropecuária Brasileira, 46, 120-129, 2011.

REDÍGOLO, S. C. R. Recuperação da palha da cana-de-açúcar para a produção de energia elétrica e etanol celulósico. 2014. 177 f. Dissertação(Mestrado em Engenharia Mecânica) - Faculdade de Engenharia, UniversidadeEstadual Paulista (UNESP), Ilha Solteira, 2014.

RIPOLI, M. L. C. Ensaio de dois sistemas de obtenção de biomassa de cana-de-açúcar (Saccharum spp.) para fins energéticos. Tese (Doutorado em Agronomia/ Energia na Agricultura)-Faculdade de Ciências Agronômicas, Universidade Estadual Paulista, Botucatu, 2004.

RIPOLI, M. L. C. Mapeamento do palhiço enfardado de cana-de-açúcar (Saccharum spp) e do seu potencial energético.Dissertação de Mestrado em Agronomia/Máquinas Agrícolas - Escola Superior de Agricultura "Luiz de Queiroz", Universidade de São Paulo, Piracicaba, 2002.

RIPOLI, T. C. C.; RIPOLI, M. L. C. Biomassa de cana-de-açúcar: colheita, energia e ambiente. Piracicaba: Edição dos Autores, 2009.

RIPOLI, T.C.C. Now it is the turn of palhiço. Idea News.; Ribeirão Preto - SP, 2001.

RIPOLI, T. C. C.; MOLINA JUNIOR, W. F.; RIPOLI, M. L. C. Energy potential of 
sugarcane biomass in Brazil. Scientia Agricola. 2000.

ROMÃO JÚNIOR, R. A. Análise da viabilidade do aproveitamento da palha da cana de açúcar para cogeração de energia numa usina sucroalcooleira. Dissertação de Mestrado Universidade Estadual Paulista “Júlio Mesquita Filho", Ilha Solteira, 2009.

RUSSELL, S. J.; NORVIG, P. Artificial Intelligence: A Modern Approach. 2. ed. New Jersey: Prentice Hall, 2003.

SANAYEI, A. et al. A. An integrated group decision-making process for supplier selection and order allocation using multi-attribute utility theory and linear programming.Journal of the Franklin Institute, 2008.

SANTOS F. A., QUEIROZ J. D. , COLODETTE J. L., MANFREDI M. QUEIROZ MELR, CALDAS C. S., SOARES F. E. Otimização do pre-tratamento hidrotérmico da palha de cana-de-açúcar visando à produção de etanol celulosico. Química Nova, 2014.

SAATY, T. L. The Analytic Hierarchy Process. N. York, USA: McGraw-Hill, 1980.

SEABRA, J. E. A.; MACEDO, I. C. Comparative analysis for power generation and ethanol production from sugarcane residual biomass in Brazil.Energy Policy Journal, 2011.

SHEEHAN J., ADEN A., PAUSTIAN K., KILLIAN K., BRENNER J., WALSH M., NELSON R. Energy and environmental aspects of using corn Stover for fuel ethanol. Journal of Industrial Ecology, 2003

SILVA JÚNIOR, A. C., ANDRADE, J. C. S., FARIAS, L. D. G. Q., TELESFORO, A. C. D. O., SOUZA, A. L. R. D., \& RAMOS, E. J. S. Políticas públicas, tecnologias limpas e sustentabilidade: MDL em parques eólicos no Brasil.Revista de Economia, Administração e Turismo, 2011.

SILVA W.R. N., NUNES M.C.M., CALDEIRA D. S. A., ARANTES E. M., SOUZA L. H. C. Resistência a penetração de um latossolo vermelho sob cultivo de cana-de-açúcar em diferentes manejos. Revista Agrotecnologia, 2012.

SILVA, J.E.A.R. Um modelo de simulação discreta para analisar o sistema integrado de canade-açúcar e aproveitamento de biomassa. Tese de Doutorado. São Carlos-SP. 2011/

SMITHERS, J. Review of sugarcane trash recovery systems for energy cogeneration in South Africa. Renewable and Sustainable Energy Reviews, 2014.

SOUSA G. B., MARTINS FILHO M. V., MATIAS S. S. R . Soil, organic matter and nutrients losses by water erosion in a slope with sugarcane straw, in Guariba, State of São Paulo. Engenharia Agrícola, 32, 490-500, 2012.

SOUZA, Z. J. Geração de energia elétrica excedente no setor sucroalcooleiro: entraves estruturais e custos de transação. São Carlos. Tese de Doutorado - Departamento de Engenharia de Produção, Universidade Federal de São Carlos, 2003.

SOUZA, Z. J. D. A co-geração de energia no setor sucroalcooleiro: desenvolvimento e situação atual. Procedings of the 4th Encontro de Energia no Meio Rural, 2002. 
SOUZA, Z. J. D., \& AZEVEDO, P. F. D. Geração de energia elétrica excedente no setor sucroalcooleiro: um estudo a partir das usinas paulistas. Revista de Economia e Sociologia rural, 44(2), 179-199, 2006.

STATISTA - The statistics portal. Disponível em:

$<$ https://www.statista.com/statistics/281606/ethanol-production-in-selected-countries/>.

Acesso em Janeiro de 2018.

SUCRE - Sugarcane Renewable Eletricity. Disponível em: <http://pages.cnpem.br/sucre/>. Acesso em Dezembro de 2016.

TOLENTINO, G.; FLORENTINO, H. O.; SARTORI, M. M. P. Modelagem matemática para o aproveitamento residual de colheita da cana-de-açúcar com menor custo. Bragantia, Campinas, 2007.

TRIVELIN P. C. O, FRANCO H. C. J., OTTO R. Impact of sugarcane trash on fertilizer requirements for S ao Paulo, Brazil. Scientia Agricola, 70, 345-352, 2013.

TROMBETA, N. C. Potencial e disponibilidade de biomassa de cana-de-açúcar na região Centro-Sul do Brasil: uma aplicação de modelos de localização ótima para fins energéticos. Dissertação de Mestrado. Universidade de São Paulo, 2015.

UNIÃO DAS INDÚSTRIAS DE CANA-DE-AÇÚCAR- UNICA. Setor Sucroenergético Mapa da Produção - Produção de etanol do Brasil. UNICA, 2010 - Disponível em: < http://www.unica.com.br> Acesso em: outubro de 2016.

UNIÃO DA INDÚSTRIA DE CANA-DE-AÇÚCAR - UNICA. Estudo da Matriz Energética. Disponível em: http://www.unica.com.br/namidia/2491311192038663351/producaode-cana-avanca-na-safra-2016-por-cento2F2017/.

Acesso em: 27 out. 2016.

VAZ, S. M. O setor sucroalcooleiro e a sustentabilidade ambiental. Rca-revista científica da Ajes, v. 2, n. 5, 2015.

VELASQUEZ, M., HESTER, P. T. An analysis of multi-criteria decision making methods. International Journal of Operations Research, 2013

VITTI A. C., TRIVELIN P. C. O., CANTARELlA H. et al. Mineralização da palhada e crescimento de raizes de cana-de-açúcar relacionados com a adubação nitrogenada de plantio.

Revista Brasileira de Ciência do Solo, 2008.

VON NEUMANN, J. MORGENSTERN, O. Theory of Games and Economic Behavior. New York: Wiley, 1953.

VON WINTERFELDT, D.; EDWARDS, W. Decision Analysis and Behavioral Research. Cambridge: Cambridge University Press, 1986. 


\section{APÊNDICES}

\section{Apêndice A- Roteiro da entrevista semiestruturada}

\section{Perfil do decisor:}

- Qual a profissão do entrevistado?

- Qual o cargo atual do entrevistado dentro da empresa?

- Quais são as principais funções do cargo?

- Quantos o tempo de experiência no cargo?

- Qual a idade do entrevistado?

- Qual o número de funcionário sob a responsabilidade do entrevistado?

- Para qual cargo o entrevistado reporta?

- Está satisfeito com o método atual da empresa de recolhimento/cogeração de energia?

- O entrevistado acredita que um modelo, composto por medidas bem definidas e considerando as preferências dos decisores, poderia melhorar as atividades ligadas ao recolhimento de palhiço da cana para a cogeração de energia?

\section{Perguntas gerais sobre o recolhimento e cogeração de energia a partir do palhiço:}

- Apresentação da empresa.

- Fale sobre o processo de cogeração com o palhiço. Qual tipo de sistema de cogeração é utilizado pela usina? Como funciona o processo?

- Fale sobre as dificuldades envolvidas no processo como um todo, desde o recolhimento da palhiço até a produção de energia elétrica.

- Quais os equipamentos foram adquiridos para iniciar a cogeração com palhiço? Quais os investimentos iniciais feitos? (indústria e campo). Detalhar os equipamentos e custos.

- A usina possui o Sistema de Limpeza à seco para retirada de impurezas da palhiço? Se sim, qual o investimento feito?

- Qual o custo operacional para fazer o recolhimento e cogeração de energia com palhiço? (Combustível, Energia, Mão-de-obra).

- Qual o nível de impureza da palhiço ao ser colocada na caldeira? E a granulometria?

- Quais fatores que interferem na decisão de utilizar a palhiço (além do bagaço) para a cogeração ? Qual a proporção palhiço/bagaço utilizada?

- Qual a importância de fatores qualitativos (como umidade da palhiço, impureza, densidade, nível de separação cana/palhiço) para a cogeração de energia com palhiço?

- Qual a quantidade de palhiço coletada e qual a quantidade deixada no solo pela usina?

- Qual o tipo de recolhimento utilizado pela usina para colher palhiço? Quais os motivos da utilização deste tipo de recolhimento? Quais os principais custos envolvidos?

- A usina é auto-suficiente em energia? Ela vende excedentes de energia? Qual a quantidade produzida para a autossuficiência e para a exportação? 
- Explique como funciona a comercialização de tais excedentes e quais os principais clientes. A usina gera energia na entressafra? Se sim, ela utiliza tanto a palhiço quanto o bagaço?

- Há necessidade de uma estrutura específica para o armazenamento da biomassa? Esse armazenamento causa danos para a biomassa?

- Qual a relevância que os fatores ambientais têm para a usina? Quais gases são emitidos na queima da biomassa?

- Quais burocracias existentes para a queima da biomassa? Explique.

- Quais incentivos ou programas criados pelo governo para a cogeração de energia que vocês usufruem/usufruíram? 


\section{Apêndice B- Levantamento de curvas de utilidade: método de certeza equivalente}

O método de certeza equivalente ou também chamado "equivalente certo" exige ao tomador de decisão a pensar em termos de apostas 50/50. Para ilustrar como o método é aplicado considera-se uma adaptação do exemplo de Varian (2006).

Os valores de utilidade máxima e mínima para o teor de impurezas do palhiço são apresentados no Quadro 41.

Quadro 41: Teor de impurezas e utilidades

\begin{tabular}{cc}
\hline Teor de impurezas & Utilidade \\
\hline $0 \%$ & 1 \\
$15 \%$ & 0 \\
\hline
\end{tabular}

Portanto: $\mathrm{u}(0)=1 ; \mathrm{u}(15)=0$

Uma sessão de elicitação típica do método de certeza equivalente pode proceder da seguinte forma:

\section{Iteração 1}

Analista: "Para um bilhete de loteria hipotética com uma chance de 50\% de obter teor de impurezas igual a $0 \%$ e $50 \%$ de chance de obter teor de impurezas de $15 \%$. Por qual valor máximo de teor de impurezas você deixaria de participar dessa loteria?

Decisor: (depois de algum tempo pensando) $=10 \%$

$$
\text { Assim: } u(10)=0.5 u(0)+0,5 u(15)=0,5(1)+0,5(0)=0,5
$$

\section{Iteração 2}

$\mathrm{O}$ analista agora usaria o teor de impurezas de $10 \%$ como o pior retorno em uma nova loteria hipotética, da seguinte forma:

Analista: "Para um bilhete de loteria hipotética com uma chance de 50\% de obter teor de impurezas igual a $0 \%$, e $50 \%$ de chance de obter teor de impurezas de $10 \%$. Por qual valor máximo de teor de impurezas você deixaria de participar dessa loteria?

Decisor: Cerca de 7\%

$$
\text { Assim: } u(7)=0.5 u(0)+0,5 u(10)=0,5(1)+0,5(0,5)=0,75
$$




\section{Iteração 3}

O valor de $10 \%$ de impurezas também é usado como o melhor retorno em uma loteria, como segue:

Analista: "Para um bilhete de loteria hipotética com uma chance de 50\% de obter teor de impurezas igual a $10 \%$, e $50 \%$ de chance de obter teor de impurezas de $15 \%$. Por qual valor máximo de teor de impurezas você deixaria de participar dessa loteria?

Decisor: Cerca de 12\%

$$
\text { Assim: } u(12)=0.5 u(10)+0,5 u(15)=0,5(0,5)+0,5(0)=0,25
$$

O efeito deste procedimento é extrair os valores que tenham utilidades de $0,0.25,0.5$, 0.75 e 1. A Figura 42 e o Quadro 42 apresentam a função de utilidade e as utilidades para o decisor no exemplo.

Quadro 42: Utilidades do teor de impurezas do exemplo

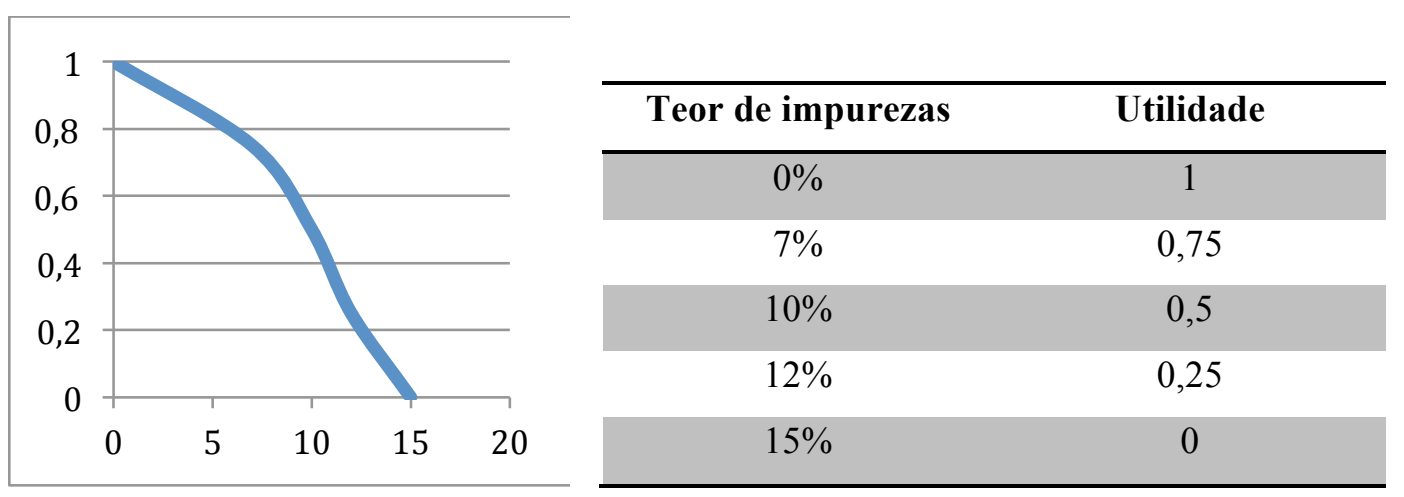

Figura 42: Função utilidade exemplo para o teor de impurezas do palhiço 


\section{Apêndice C- Outros métodos de ponderação de critérios}

Método Trade-off Weighting. O decisor compara duas alternativas que se diferenciam por apenas dois critérios quando os outros critérios são mantidos fixos ou desconsiderados. É realizado um ajuste em um dos critérios até que as alternativas contenham igualdade de preferências (KEENEY; RAIFFA, 1976).

Método de atribuição direta (Direct Rating). O decisor é convidado a ordenar de maneira decrescente os critérios (GOODWIN; WRIGHT, 2005). É atribuído o valor 100 para o critério mais relevante e 0 para o menos relevante, os demais são posicionados pelo decisor entre estes dois critérios. Os valores relativos ao posicionamento de todos os critérios representam a quantificação dos critérios segundo a preferência do tomador de decisões.

Método Swing Weighting. O decisor é convidado a considerar a situação hipotética de uma alternativa que possui a menor pontuação em todos os critérios envolvidos no processo de decisão (GOODWIN; WRIGHT, 2005). Com isso é criada uma situação de benchmark (referência), caracterizada pelo pior cenário (VON WINTERFELDT; EDWARDS, 1986).

O decisor atribui 100 pontos para o critério que decide elevar à maior pontuação possível. Após atribuir 100 pontos para esse critério, é eliminado do processo. O decisor consulta os critérios restantes e novamente escolhe o critério que gostaria de elevar e atribui um valor inferior a 100 pontos e assim sucessivamente (MUSTAJOKI; HAMALAINEN; LINDSTEDT, 2006). Portanto, o decisor atribui uma ponderação para cada critério partindo do mais relevante até o critério com pouca relevância. O Quadro 43 apresenta o exemplo de ponderação utilizando a técnica interativa Swing Weighting, onde o peso do critério é igual à nota do critério divida pela soma de todas as notas.

Quadro 43: Atribuição de pesos com Swing Weighting

\begin{tabular}{cccc}
\hline Critérios & Ranking & Nota & Peso \\
\hline Critério A - menos & 3 & 0 & $0 / 130=0$ \\
relevante & & & $100 / 130=$ \\
Critério B & 1 & 100 & 0,76923 \\
& & & $30 / 130=$ \\
Critério C & 2 & 30 & 0,23076 \\
\hline Somatório & & & $\mathbf{1}$ \\
\hline
\end{tabular}


Método AHP. De forma geral, o processo de análises hierárquico é uma abordagem de comparação de alternativas quando um decisor é confrontado com um problema que envolve múltiplos critérios. O método foi desenvolvido por Thomas Saaty em 1970 e tem sido utilizado em áreas como economia, planejamento, política energética, seleção de projeto, entre outras (GOODWIN; WRIGHT, 2005).

Saaty (1980) aprimorou o AHP por meio da derivação das escalas prioritárias ao comparar um elemento a outro. Esta comparação é feita com o auxílio da escala fundamental com valores de 1-9 (Quadro 44). Através desta escala, o decisor pode expressar as suas preferências em relação aos dois elementos que estão sendo comparados. Essa escala é usada usualmente para medir elementos intangíveis em termos relativos. Segundo o autor, a tomada de decisão envolve muitos critérios utilizados para classificar as alternativas e muitas vezes esses critérios são de natureza intangível, onde não há medidas que sirvam como guia para classificar as alternativas e criar prioridades entre elas.

Quadro 44: Escala fundamental de Saaty. Fonte: Saaty (1980)

\begin{tabular}{cc}
\hline Intensidade & Definição \\
\hline 1 & Igual importância \\
3 & Importância pequena de uma sobre a outra \\
5 & Importância relativa de uma sobre a outra \\
7 & Importância muito forte de uma sobre a outra \\
9 & Importância absoluta de uma sobre a outra \\
$2,4,6,8$ & Valores intermediários que caracterizam a excitação do decisor entre 2 \\
Recíprocos & patamares \\
dos números & Se o elemento i possui um dos números acima, quando comparado com o \\
acima & elemento j, o elemento j possuirá o valor inverso comparado com i. \\
\hline
\end{tabular}

Apesar de o AHP ser uma alternativa ao SMART para auxilio à tomada de decisão multicritério, nesta dissertação ele é usado unicamente como um método de ponderação de critérios. Isto devido a que sua estrutura axiomática como método de comparação de alternativas tem sido muito criticada (GOODWIN; WRIGHT, 2005, p. 421). No entanto tem demonstrado ser uma ferramenta muito utilizada e aceitada na ponderação de critérios. Vaidya e Kumar (2006) realizaram uma revisão de literatura sobre aplicações AHP em 150 artigos estudados. Os autores encontraram que AHP é amplamente aplicado na área de engenharia, especificamente para problemas de seleção e avaliação. Ressaltaram também a flexibilidade do AHP para ser combinado com outras técnicas de tomada de decisão. 
Adicionalmente, Subramanian e Ramanathan (2012) realizaram uma revisão de literatura sobre aplicações AHP na gestão de operações sobre 291 artigos estudados. Os autores descobriram que o AHP tem sido principalmente aplicado na gestão da cadeia de suprimentos, especificamente para problemas de localização, seleção de fornecedores, desenhos e avaliação de redes de suprimentos, entre outros. Os autores também indicaram que $80 \%$ das aplicações AHP em gestão de operações foram para casos práticos e em 51\% dos casos o AHP foi combinado com outros métodos, sendo: método Delphi, Enfoque Bayesiano, análise envoltória de dados, programação linear, algoritmos genéticos, programação de metas, simulação, entre outros.

Os passos do AHP como definido por Saaty (1980) são, basicamente, a comparação entre pares de critérios, determinação do vetor de prioridades e determinação do índice de inconsistência. 


\section{Apêndice D- Hierarquização dos critérios - SMART}

Para a hierarquização dos critérios, o decisor deve atribuir ponderações indicando suas preferências em relação ao conjunto de critérios. Foi utilizado o método SMART para esta etapa.

Analista: Considerando os critérios gerais: "custos", "variáveis agroindustriais" e "custos operacionais", qual deles você considera o de menor importância?

Decisor: Resposta.

Então é atribuído o valor 10 para o critério de menor importância.

Analista: Em comparação a este critério de menor preferência, quantas vezes você considera os outros critérios mais importantes?

São atribuídos pesos proporcionais e maiores que 10 para os outros critérios.

Analista: Considerando os subcritérios de "custo": "custos operacionais" e "custos de investimentos", qual deles você considera o de menor importância?

Decisor: Resposta.

Então é atribuído o valor 10 para o critério de menor importância.

Analista: Em comparação a este critério de menor preferência, quantas vezes você considera o outro critério mais importante?

É atribuído peso proporcional e maior que 10 para o outro critério.

Analista: Considerando os subcritérios das "variáveis agroindustriais": "variáveis agronômicas" e "variáveis industriais", qual deles você considera o de menor importância? Decisor: Resposta.

Então é atribuído o valor 10 para o critério de menor importância.

Analista: Em comparação a este critério de menor preferência, quantas vezes você considera o outro critério mais importante?

É atribuído peso proporcional e maior que 10 para o outro critério.

Analista: Considerando os subcritérios dos "custos operacionais: "combustível/energia", "mão-de-obra", "manutenção" e "outros custos operacionais", qual deles você considera o de menor importância?

Decisor: Resposta 
Então é atribuído o valor 10 para o critério de menor importância.

Analista: Em comparação a este critério de menor preferência, quantas vezes você considera os outros critérios mais importantes?

São atribuídos pesos proporcionais e maiores que 10 para os outros critérios.

Analista: Considerando os subcritérios dos "custos de investimentos": "enfardadora", "enleiradora" "transporte de fardos", "sistema de limpeza a seco" e "outros investimentos" qual deles você considera o de menor importância?

Decisor: Resposta

Então é atribuído o valor 10 para o critério de menor importância.

Analista: Em comparação a este critério de menor preferência, quantas vezes você considera os outros critérios mais importantes?

São atribuídos pesos proporcionais e maiores que 10 para os outros critérios.

Analista: Considerando os subcritérios das "variáveis agronômicas": "umidade" e “qualidade do palhiço", qual deles você considera o de menor importância?

Decisor: Resposta

Então é atribuído o valor 10 para o critério de menor importância.

Analista: Em comparação a este critério de menor preferência, quantas vezes você considera os outros critérios mais importantes?

É atribuído peso proporcional e maior que 10 para o outro critério.

Analista: Considerando os subcritérios das "variáveis industriais": "eficiência de separação cana/palhiço" e "produtividade de cogeração", qual deles você considera o de menor importância?

Decisor: Resposta

Então é atribuído o valor 10 para o critério de menor importância.

Analista: Em comparação a este critério de menor preferência, quantas vezes você considera os outros critérios mais importantes?

É atribuído peso proporcional e maior que 10 para o outro critério. 


\section{Apêndice E- Análise de Monte Carlo}

O Quadro 45 apresenta as 200 simulações geradas pela análise de Monte Carlo, apresentando os 200 números aleatórios de preço de energia, suas respectivas receitas e utilidades para cada alternativa de recolhimento de palhiço e a alternativa sugerida.

Quadro 45: Receitas, utilidades e alternativa sugerida para os preços de energia aleatórios

\begin{tabular}{|c|c|c|c|c|c|c|c|}
\hline $\begin{array}{l}\text { Preço da } \\
\text { energia }\end{array}$ & $\begin{array}{c}\text { Receita } \\
\text { enfardamento }\end{array}$ & $\begin{array}{c}\text { Receita C. } \\
\text { Integral }\end{array}$ & $\begin{array}{c}\text { Receita C. } \\
\text { Parcial }\end{array}$ & $\begin{array}{c}\text { Utilidade } \\
\text { Enfardamento }\end{array}$ & $\begin{array}{l}\text { Utilidade } \\
\text { C.integral }\end{array}$ & $\begin{array}{l}\text { Utildade } \\
\text { C.parcial }\end{array}$ & $\begin{array}{c}\text { Alternativa } \\
\text { sugerida }\end{array}$ \\
\hline 18,94 & 1515505 & 1326067 & 663034 & 0 & 0 & 0 & c.parcial \\
\hline 20,61 & 1648797 & 1442697 & 721348 & 0 & 0 & 0 & c.parcial \\
\hline 24,36 & 1948401 & 1704851 & 852425 & 0 & 0 & 0 & c.parcial \\
\hline 35,50 & 2840397 & 2485347 & 1242674 & 0 & 0 & 0 & c.parcial \\
\hline 48,03 & 3842209 & 3361933 & 1680967 & 0 & 0 & 0 & c.parcial \\
\hline 48,73 & 3898496 & 3411184 & 1705592 & 0 & 0 & 0 & c.parcial \\
\hline 48,93 & 3914552 & 3425233 & 1712617 & 0 & 0 & 0 & c.parcial \\
\hline 49,30 & 3944202 & 3451177 & 1725588 & 0 & 0 & 0 & c.parcial \\
\hline 50,49 & 4039452 & 3534520 & 1767260 & 0 & 0 & 0 & c.parcial \\
\hline 52,34 & 4187347 & 3663928 & 1831964 & 0 & 0 & 0 & c.parcial \\
\hline 53,50 & 4280378 & 3745331 & 1872665 & 0 & 0 & 0 & c.parcial \\
\hline 57,86 & 4628910 & 4050296 & 2025148 & 0 & 0 & 0 & c.parcial \\
\hline 57,94 & 4635580 & 4056132 & 2028066 & 0 & 0 & 0 & c.parcial \\
\hline 58,32 & 4665957 & 4082712 & 2041356 & 0 & 0 & 0 & c.parcial \\
\hline 58,86 & 4708792 & 4120193 & 2060097 & 0 & 0 & 0 & c.parcial \\
\hline 61,52 & 4921904 & 4306666 & 2153333 & 0 & 0 & 0 & c.parcial \\
\hline 65,32 & 5225730 & 4572514 & 2286257 & 0 & 0 & 0 & c.parcial \\
\hline 66,53 & 5322276 & 4656992 & 2328496 & 0 & 0 & 0 & c.parcial \\
\hline 68,82 & 5505612 & 4817411 & 2408705 & 0 & 0 & 0 & c.parcial \\
\hline 72,23 & 5778168 & 5055897 & 2527948 & 0 & 0 & 0 & c.parcial \\
\hline 74,63 & 5970170 & 5223899 & 2611950 & 0 & 0 & 0 & c.parcial \\
\hline 74,99 & 5999119 & 5249229 & 2624614 & 0 & 0 & 0 & c.parcial \\
\hline 94,82 & 7585361 & 6637191 & 3318595 & 5 & 2 & 0 & c.parcial \\
\hline 98,77 & 7901855 & 6914123 & 3457062 & 7 & 3 & 0 & c.parcial \\
\hline 98,99 & 7918881 & 6929021 & 3464511 & 7 & 3 & 0 & c.parcial \\
\hline 109,52 & 8761652 & 7666446 & 3833223 & 10 & 6 & 0 & c.parcial \\
\hline 109,74 & 8779295 & 7681883 & 3840942 & 10 & 6 & 0 & c.parcial \\
\hline 110,99 & 8879444 & 7769514 & 3884757 & 10 & 6 & 0 & c.parcial \\
\hline 111,36 & 8908950 & 7795331 & 3897665 & 10 & 6 & 0 & c.parcial \\
\hline 118,94 & 9515106 & 8325718 & 4162859 & 12 & 8 & 0 & c.parcial \\
\hline 120,83 & 9666113 & 8457849 & 4228924 & 13 & 8 & 0 & c.parcial \\
\hline 121,42 & 9713695 & 8499483 & 4249741 & 13 & 9 & 0 & c.parcial \\
\hline 128,85 & 10308288 & 9019752 & 4509876 & 15 & 10 & 0 & c.parcial \\
\hline 129,92 & 10393398 & 9094223 & 4547112 & 15 & 11 & 0 & c.parcial \\
\hline
\end{tabular}




\begin{tabular}{|c|c|c|c|c|c|c|c|}
\hline 130,25 & 10420316 & 9117776 & 4558888 & 15 & 11 & 0 & c.parcial \\
\hline 135,32 & 10825718 & 9472503 & 4736252 & 17 & 12 & 0 & c.parcial \\
\hline 136,70 & 10936378 & 9569330 & 4784665 & 17 & 12 & 0 & c.parcial \\
\hline 140,64 & 11250973 & 9844602 & 4922301 & 18 & 13 & 0 & c.parcial \\
\hline 141,16 & 11292741 & 9881149 & 4940574 & 18 & 13 & 0 & c.parcial \\
\hline 141,35 & 11307799 & 9894324 & 4947162 & 18 & 13 & 0 & c.parcial \\
\hline 142,89 & 11431051 & 10002169 & 5001085 & 19 & 14 & 0 & c.parcial \\
\hline 144,69 & 11574963 & 10128093 & 5064046 & 19 & 14 & 0 & c.parcial \\
\hline 145,36 & 11629136 & 10175494 & 5087747 & 19 & 14 & 0 & c.parcial \\
\hline 145,59 & 11647139 & 10191247 & 5095623 & 19 & 14 & 0 & c.parcial \\
\hline 147,39 & 11791220 & 10317317 & 5158659 & 20 & 15 & 0 & c.parcial \\
\hline 149,01 & 11920733 & 10430641 & 5215321 & 20 & 15 & 0 & c.parcial \\
\hline 156,77 & 12541391 & 10973717 & 5486859 & 23 & 17 & 0 & c.parcial \\
\hline 161,13 & 12890397 & 11279097 & 5639548 & 24 & 18 & 0 & c.parcial \\
\hline 163,76 & 13100564 & 11462993 & 5731497 & 24 & 19 & 0 & $\begin{array}{c}\text { c.integral/c } \\
\text {.parcial }\end{array}$ \\
\hline 164,01 & 13120843 & 11480738 & 5740369 & 25 & 19 & 0 & $\begin{array}{c}\text { c.integral/c } \\
\text {.parcial }\end{array}$ \\
\hline 164,86 & 13188445 & 11539889 & 5769945 & 25 & 19 & 0 & $\begin{array}{c}\text { c.integral/c } \\
\text {.parcial }\end{array}$ \\
\hline 166,13 & 13290685 & 11629350 & 5814675 & 25 & 19 & 0 & $\begin{array}{c}\text { c.integral/c } \\
\text {.parcial }\end{array}$ \\
\hline 167,11 & 13369054 & 11697922 & 5848961 & 25 & 20 & 0 & $\begin{array}{c}\text { c.integral/c } \\
\text {.parcial }\end{array}$ \\
\hline 167,45 & 13395754 & 11721285 & 5860642 & 26 & 20 & 0 & $\begin{array}{c}\text { c.integral/c } \\
\text {.parcial }\end{array}$ \\
\hline 169,91 & 13593049 & 11893918 & 5946959 & 26 & 20 & 0 & $\begin{array}{c}\text { c.integral/c } \\
\text {.parcial }\end{array}$ \\
\hline 171,73 & 13738390 & 12021092 & 6010546 & 27 & 21 & 0 & $\begin{array}{c}\text { c.integral/c } \\
\text {.parcial }\end{array}$ \\
\hline 172,88 & 13830299 & 12101512 & 6050756 & 27 & 21 & 0 & $\begin{array}{l}\text { c.integral/c } \\
\text {.parcial }\end{array}$ \\
\hline 174,06 & 13924561 & 12183991 & 6091995 & 27 & 21 & 0 & $\begin{array}{l}\text { c.integral/c } \\
\text {.parcial }\end{array}$ \\
\hline 174,45 & 13955860 & 12211378 & 6105689 & 27 & 21 & 0 & $\begin{array}{c}\text { c.integral/c } \\
\text {.parcial }\end{array}$ \\
\hline 177,29 & 14182935 & 12410068 & 6205034 & 28 & 22 & 1 & $\begin{array}{c}\text { c.integral/c } \\
\text {.parcial }\end{array}$ \\
\hline 177,96 & 14236835 & 12457230 & 6228615 & 28 & 22 & 1 & $\begin{array}{l}\text { c.integral/c } \\
\text {.parcial }\end{array}$ \\
\hline 186,29 & 14903139 & 13040247 & 6520123 & 31 & 24 & 2 & C.integral \\
\hline 186,98 & 14958185 & 13088412 & 6544206 & 31 & 24 & 2 & C.integral \\
\hline 187,29 & 14982867 & 13110008 & 6555004 & 31 & 25 & 2 & C.integral \\
\hline 188,47 & 15077358 & 13192688 & 6596344 & 31 & 25 & 2 & C.integral \\
\hline 189,01 & 15121116 & 13230976 & 6615488 & 31 & 25 & 2 & C.integral \\
\hline 193,30 & 15464068 & 13531060 & 6765530 & 33 & 26 & 3 & C.integral \\
\hline 194,48 & 15558286 & 13613500 & 6806750 & 33 & 26 & 3 & C.integral \\
\hline 196,99 & 15758871 & 13789012 & 6894506 & 34 & 27 & 3 & C.integral \\
\hline 199,41 & 15952985 & 13958862 & 6979431 & 34 & 27 & 3 & C.integral \\
\hline 201,54 & 16123530 & 14108088 & 7054044 & 35 & 28 & 4 & C.integral \\
\hline
\end{tabular}




\begin{tabular}{|c|c|c|c|c|c|c|c|}
\hline 201,95 & 16155895 & 14136409 & 7068204 & 35 & 28 & 4 & C.integral \\
\hline 202,67 & 16213772 & 14187051 & 7093525 & 35 & 28 & 4 & C.integral \\
\hline 210,30 & 16824157 & 14721138 & 7360569 & 37 & 30 & 5 & C.integral \\
\hline 215,28 & 17222732 & 15069891 & 7534945 & 39 & 31 & 5 & C.integral \\
\hline 224,38 & 17950722 & 15706881 & 7853441 & 41 & 33 & 6 & C.integral \\
\hline 225,46 & 18037102 & 15782464 & 7891232 & 42 & 34 & 7 & C.integral \\
\hline 227,68 & 18214534 & 15937717 & 7968859 & 42 & 34 & 7 & C.integral \\
\hline 230,75 & 18460386 & 16152837 & 8076419 & 43 & 35 & 7 & C.integral \\
\hline 232,41 & 18592736 & 16268644 & 8134322 & 43 & 35 & 7 & C.integral \\
\hline 232,95 & 18635616 & 16306164 & 8153082 & 44 & 36 & 7 & C.integral \\
\hline 247,37 & 19789844 & 17316114 & 8658057 & 48 & 39 & 9 & C.integral \\
\hline 251,53 & 20122223 & 17606945 & 8803473 & 49 & 40 & 10 & C.integral \\
\hline 252,12 & 20169416 & 17648239 & 8824119 & 49 & 40 & 10 & C.integral \\
\hline 260,82 & 20865519 & 18257329 & 9128664 & 51 & 42 & 11 & C.integral \\
\hline 261,55 & 20923880 & 18308395 & 9154198 & 51 & 42 & 11 & C.integral \\
\hline 270,76 & 21660966 & 18953345 & 9476672 & 54 & 45 & 12 & C.integral \\
\hline 273,49 & 21879333 & 19144417 & 9572208 & 55 & 45 & 12 & C.integral \\
\hline 276,35 & 22108301 & 19344763 & 9672382 & 56 & 46 & 13 & C.integral \\
\hline 278,79 & 22303529 & 19515588 & 9757794 & 56 & 47 & 13 & C.integral \\
\hline 281,66 & 22532412 & 19715860 & 9857930 & 57 & 47 & 13 & C.integral \\
\hline 289,64 & 23171062 & 20274679 & 10137340 & 59 & 49 & 14 & C.integral \\
\hline 295,04 & 23603483 & 20653048 & 10326524 & 61 & 51 & 15 & C.integral \\
\hline 298,89 & 23911206 & 20922306 & 10461153 & 62 & 51 & 15 & C.integral \\
\hline 302,16 & 24173072 & 21151438 & 10575719 & 63 & 52 & 16 & $\begin{array}{c}\text { Enfard/c.in } \\
\text { tegral }\end{array}$ \\
\hline 302,23 & 24178008 & 21155757 & 10577879 & 63 & 52 & 16 & $\begin{array}{c}\text { Enfard/c.in } \\
\text { tegral }\end{array}$ \\
\hline 305,44 & 24435306 & 21380893 & 10690446 & 64 & 53 & 16 & $\begin{array}{c}\text { Enfard/c.in } \\
\text { tegral }\end{array}$ \\
\hline 308,17 & 24653716 & 21572001 & 10786001 & 64 & 54 & 17 & $\begin{array}{c}\text { Enfard/c.in } \\
\text { tegral }\end{array}$ \\
\hline 309,95 & 24795690 & 21696229 & 10848114 & 65 & 54 & 17 & $\begin{array}{c}\text { Enfard/c.in } \\
\text { tegral }\end{array}$ \\
\hline 314,54 & 25163204 & 22017804 & 11008902 & 66 & 55 & 17 & $\begin{array}{c}\text { Enfard/c.in } \\
\text { tegral }\end{array}$ \\
\hline 319,51 & 25560513 & 22365449 & 11182724 & 67 & 56 & 18 & $\begin{array}{c}\text { Enfard/c.in } \\
\text { tegral }\end{array}$ \\
\hline 330,67 & 26453877 & 23147142 & 11573571 & 71 & 59 & 19 & $\begin{array}{c}\text { Enfard/c.in } \\
\text { tegral }\end{array}$ \\
\hline 332,37 & 26589985 & 23266237 & 11633118 & 71 & 60 & 19 & $\begin{array}{c}\text { Enfard/c.in } \\
\text { tegral }\end{array}$ \\
\hline 340,30 & 27224080 & 23821070 & 11910535 & 73 & 61 & 20 & $\begin{array}{c}\text { Enfard/c.in } \\
\text { tegral }\end{array}$ \\
\hline 342,45 & 27396251 & 23971720 & 11985860 & 74 & 62 & 21 & $\begin{array}{c}\text { Enfard/c.in } \\
\text { tegral }\end{array}$ \\
\hline 342,75 & 27419687 & 23992226 & 11996113 & 74 & 62 & 21 & $\begin{array}{c}\text { Enfard/c.in } \\
\text { tegral }\end{array}$ \\
\hline 346,56 & 27725022 & 24259394 & 12129697 & 75 & 63 & 21 & $\begin{array}{c}\text { Enfard/c.in } \\
\text { tegral }\end{array}$ \\
\hline 347,45 & 27795756 & 24321287 & 12160643 & 75 & 63 & 21 & Enfard/c.in \\
\hline
\end{tabular}




\begin{tabular}{|c|c|c|c|c|c|c|c|}
\hline & & & & & & & tegral \\
\hline 350,51 & 28040553 & 24535484 & 12267742 & 76 & 64 & 22 & $\begin{array}{c}\text { Enfard/c.in } \\
\text { tegral }\end{array}$ \\
\hline 354,86 & 28388755 & 24840161 & 12420080 & 77 & 65 & 22 & $\begin{array}{c}\text { Enfard/c.in } \\
\text { tegral }\end{array}$ \\
\hline 356,05 & 28483895 & 24923408 & 12461704 & 78 & 65 & 22 & $\begin{array}{c}\text { Enfardame } \\
\text { nto }\end{array}$ \\
\hline 357,32 & 28585992 & 25012743 & 12506371 & 78 & 66 & 22 & $\begin{array}{c}\text { Enfard/c.in } \\
\text { tegral }\end{array}$ \\
\hline 358,12 & 28649801 & 25068576 & 12534288 & 78 & 66 & 23 & $\begin{array}{c}\text { Enfardame } \\
\text { nto }\end{array}$ \\
\hline 361,00 & 28879985 & 25269987 & 12634993 & 79 & 66 & 23 & $\begin{array}{c}\text { Enfard/c.in } \\
\text { tegral }\end{array}$ \\
\hline 370,25 & 29620346 & 25917803 & 12958901 & 81 & 69 & 24 & $\begin{array}{c}\text { Enfard/c.in } \\
\text { tegral }\end{array}$ \\
\hline 373,24 & 29859185 & 26126787 & 13063393 & 82 & 69 & 24 & $\begin{array}{c}\text { Enfard/c.in } \\
\text { tegral }\end{array}$ \\
\hline 379,67 & 30373536 & 26576844 & 13288422 & 84 & 71 & 25 & $\begin{array}{c}\text { Enfard/c.in } \\
\text { tegral }\end{array}$ \\
\hline 379,69 & 30375483 & 26578547 & 13289274 & 84 & 71 & 25 & $\begin{array}{c}\text { Enfard/c.in } \\
\text { tegral }\end{array}$ \\
\hline 386,03 & 30882140 & 27021872 & 13510936 & 86 & 73 & 26 & $\begin{array}{c}\text { Enfardame } \\
\text { nto }\end{array}$ \\
\hline 387,41 & 30992477 & 27118417 & 13559209 & 86 & 73 & 26 & $\begin{array}{c}\text { Enfardame } \\
\text { nto }\end{array}$ \\
\hline 387,83 & 31026286 & 27148000 & 13574000 & 86 & 73 & 26 & $\begin{array}{c}\text { Enfardame } \\
\text { nto }\end{array}$ \\
\hline 388,40 & 31072235 & 27188205 & 13594103 & 86 & 73 & 26 & $\begin{array}{c}\text { Enfardame } \\
\text { nto }\end{array}$ \\
\hline 389,66 & 31173139 & 27276496 & 13638248 & 87 & 73 & 26 & $\begin{array}{c}\text { Enfardame } \\
\text { nto }\end{array}$ \\
\hline 390,85 & 31267739 & 27359271 & 13679636 & 87 & 74 & 26 & $\begin{array}{c}\text { Enfard/c.in } \\
\text { tegral }\end{array}$ \\
\hline 390,92 & 31273403 & 27364228 & 13682114 & 87 & 74 & 27 & $\begin{array}{c}\text { Enfard/c.in } \\
\text { tegral }\end{array}$ \\
\hline 398,96 & 31917014 & 27927387 & 13963693 & 89 & 76 & 27 & $\begin{array}{c}\text { Enfard/c.in } \\
\text { tegral }\end{array}$ \\
\hline 399,04 & 31922892 & 27932531 & 13966265 & 89 & 76 & 27 & $\begin{array}{c}\text { Enfard/c.in } \\
\text { tegral }\end{array}$ \\
\hline 399,23 & 31938512 & 27946198 & 13973099 & 89 & 76 & 28 & $\begin{array}{c}\text { Enfard/c.in } \\
\text { tegral }\end{array}$ \\
\hline 399,78 & 31982749 & 27984905 & 13992453 & 90 & 76 & 28 & $\begin{array}{c}\text { Enfard/c.in } \\
\text { tegral }\end{array}$ \\
\hline 409,79 & 32783046 & 28685165 & 14342583 & 92 & 78 & 29 & $\begin{array}{c}\text { Enfardame } \\
\text { nto }\end{array}$ \\
\hline 416,45 & 33315988 & 29151489 & 14575745 & 94 & 80 & 30 & $\begin{array}{c}\text { Enfardame } \\
\text { nto }\end{array}$ \\
\hline 420,55 & 33643784 & 29438311 & 14719156 & 95 & 81 & 30 & $\begin{array}{c}\text { Enfard/c.in } \\
\text { tegral }\end{array}$ \\
\hline 425,91 & 34073030 & 29813901 & 14906950 & 97 & 82 & 31 & $\begin{array}{c}\text { Enfardame } \\
\text { nto }\end{array}$ \\
\hline
\end{tabular}




\begin{tabular}{|c|c|c|c|c|c|c|c|}
\hline 436,05 & 34884093 & 30523581 & 15261791 & 100 & 85 & 32 & $\begin{array}{c}\text { Enfardame } \\
\text { nto }\end{array}$ \\
\hline 440,67 & 35253827 & 30847098 & 15423549 & 100 & 86 & 33 & $\begin{array}{c}\text { Enfard/c.in } \\
\text { tegral }\end{array}$ \\
\hline 441,24 & 35299024 & 30886646 & 15443323 & 100 & 86 & 33 & $\begin{array}{c}\text { Enfardame } \\
\text { nto }\end{array}$ \\
\hline 447,63 & 35810681 & 31334346 & 15667173 & 100 & 87 & 33 & $\begin{array}{c}\text { Enfard/c.in } \\
\text { tegral }\end{array}$ \\
\hline 466,13 & 37290467 & 32629158 & 16314579 & 100 & 92 & 36 & C.integral \\
\hline 466,55 & 37323686 & 32658225 & 16329113 & 100 & 92 & 36 & C.integral \\
\hline 477,51 & 38201089 & 33425953 & 16712976 & 100 & 95 & 37 & C.integral \\
\hline 501,94 & 40154997 & 35135622 & 17567811 & 100 & 100 & 40 & C.integral \\
\hline 505,04 & 40402886 & 35352525 & 17676263 & 100 & 100 & 40 & C.integral \\
\hline 508,43 & 40674150 & 35589881 & 17794941 & 100 & 100 & 41 & C.integral \\
\hline 513,38 & 41070205 & 35936430 & 17968215 & 100 & 100 & 41 & C.integral \\
\hline 521,74 & 41739116 & 36521726 & 18260863 & 100 & 100 & 42 & C.integral \\
\hline 532,67 & 42613476 & 37286791 & 18643396 & 100 & 100 & 44 & C.integral \\
\hline 535,78 & 42862253 & 37504472 & 18752236 & 100 & 100 & 44 & C.integral \\
\hline 541,06 & 43284773 & 37874176 & 18937088 & 100 & 100 & 45 & C.integral \\
\hline 547,00 & 43760166 & 38290145 & 19145073 & 100 & 100 & 45 & C.integral \\
\hline 550,90 & 44072263 & 38563230 & 19281615 & 100 & 100 & 46 & C.integral \\
\hline 557,28 & 44582349 & 39009555 & 19504778 & 100 & 100 & 47 & C.integral \\
\hline 561,26 & 44900945 & 39288327 & 19644164 & 100 & 100 & 47 & C.integral \\
\hline 571,30 & 45704039 & 39991034 & 19995517 & 100 & 100 & 48 & C.integral \\
\hline 573,65 & 45891995 & 40155495 & 20077748 & 100 & 100 & 49 & C.integral \\
\hline 581,89 & 46550960 & 40732090 & 20366045 & 100 & 100 & 50 & C.integral \\
\hline 597,61 & 47808555 & 41832485 & 20916243 & 100 & 100 & 51 & C.integral \\
\hline 609,97 & 48797456 & 42697774 & 21348887 & 100 & 100 & 53 & C.integral \\
\hline 633,74 & 50699325 & 44361909 & 22180954 & 100 & 100 & 56 & C.integral \\
\hline 639,25 & 51140395 & 44747846 & 22373923 & 100 & 100 & 56 & C.integral \\
\hline 652,36 & 52188591 & 45665017 & 22832509 & 100 & 100 & 58 & C.integral \\
\hline 653,78 & 52302317 & 45764527 & 22882264 & 100 & 100 & 58 & C.integral \\
\hline 671,62 & 53729474 & 47013290 & 23506645 & 100 & 100 & 60 & C.integral \\
\hline 694,28 & 55542412 & 48599610 & 24299805 & 100 & 100 & 63 & C.integral \\
\hline 698,74 & 55899454 & 48912022 & 24456011 & 100 & 100 & 64 & C.integral \\
\hline 702,73 & 56218695 & 49191358 & 24595679 & 100 & 100 & 64 & C.integral \\
\hline 710,64 & 56851034 & 49744655 & 24872327 & 100 & 100 & 65 & C.integral \\
\hline 717,62 & 57409763 & 50233543 & 25116771 & 100 & 100 & 66 & C.integral \\
\hline 718,86 & 57508557 & 50319988 & 25159994 & 100 & 100 & 66 & C.integral \\
\hline 727,32 & 58185612 & 50912410 & 25456205 & 100 & 100 & 67 & C.integral \\
\hline 730,80 & 58463761 & 51155791 & 25577895 & 100 & 100 & 68 & C.integral \\
\hline 731,00 & 58479820 & 51169843 & 25584921 & 100 & 100 & 68 & C.integral \\
\hline 731,93 & 58554225 & 51234947 & 25617473 & 100 & 100 & 68 & C.integral \\
\hline 741,03 & 59282241 & 51871960 & 25935980 & 100 & 100 & 69 & C.integral \\
\hline 752,65 & 60212142 & 52685624 & 26342812 & 100 & 100 & 70 & C.integral \\
\hline 761,26 & 60900902 & 53288290 & 26644145 & 100 & 100 & 71 & C.integral \\
\hline 764,61 & 61168439 & 53522384 & 26761192 & 100 & 100 & 72 & C.integral \\
\hline 767,58 & 61406559 & 53730739 & 26865370 & 100 & 100 & 72 & C.integral \\
\hline 768,39 & 61471147 & 53787253 & 26893627 & 100 & 100 & 72 & C.integral \\
\hline 769,49 & 61559026 & 53864148 & 26932074 & 100 & 100 & 72 & C.integral \\
\hline
\end{tabular}




\begin{tabular}{|llllllll}
\hline $\mathbf{7 7 2 , 4 0}$ & 61792184 & 54068161 & 27034080 & 100 & 100 & 73 & C.integral \\
\hline $\mathbf{7 8 6 , 9 6}$ & 62957121 & 55087481 & 27543741 & 100 & 100 & 74 & C.integral \\
\hline $\mathbf{7 8 8 , 0 2}$ & 63041896 & 55161659 & 27580830 & 100 & 100 & 74 & C.integral \\
\hline $\mathbf{7 8 9 , 0 8}$ & 63126552 & 55235733 & 27617866 & 100 & 100 & 75 & C.integral \\
\hline $\mathbf{7 9 9 , 1 7}$ & 63933215 & 55941563 & 27970781 & 100 & 100 & 76 & C.integral \\
\hline $\mathbf{8 1 1 , 4 8}$ & 64918396 & 56803597 & 28401798 & 100 & 100 & 77 & C.integral \\
\hline $\mathbf{8 1 3 , 5 5}$ & 65084365 & 56948819 & 28474410 & 100 & 100 & 78 & C.integral \\
\hline $\mathbf{8 1 3 , 7 9}$ & 65103179 & 56965282 & 28482641 & 100 & 100 & 78 & C.integral \\
\hline $\mathbf{8 2 2 , 7 9}$ & 65822850 & 57594994 & 28797497 & 100 & 100 & 79 & c.integral/c \\
& & & & & & & .parcial \\
\hline $\mathbf{8 3 4 , 6 9}$ & 66775366 & 58428445 & 29214222 & 100 & 100 & 80 & c.integral/c \\
& & & & & & & .parcial \\
\hline $\mathbf{8 4 4 , 4 8}$ & 67558492 & 59113681 & 29556840 & 100 & 100 & 81 & c.parcial \\
\hline $\mathbf{8 5 0 , 5 5}$ & 68044373 & 59538826 & 29769413 & 100 & 100 & 82 & c.parcial \\
\hline $\mathbf{8 6 2 , 3 8}$ & 68990566 & 60366745 & 30183373 & 100 & 100 & 83 & c.parcial \\
\hline $\mathbf{8 7 2 , 8 9}$ & 69831337 & 61102420 & 30551210 & 100 & 100 & 85 & c.parcial \\
\hline $\mathbf{8 7 5 , 9 0}$ & 70072166 & 61313145 & 30656573 & 100 & 100 & 85 & c.parcial \\
\hline $\mathbf{8 7 5 , 9 6}$ & 70076911 & 61317297 & 30658649 & 100 & 100 & 85 & c.parcial \\
\hline $\mathbf{8 8 1 , 4 2}$ & 70513234 & 61699080 & 30849540 & 100 & 100 & 86 & c.parcial \\
\hline $\mathbf{8 8 4 , 2 7}$ & 70741981 & 61899233 & 30949617 & 100 & 100 & 86 & c.parcial \\
\hline $\mathbf{8 9 0 , 3 8}$ & 71230490 & 62326679 & 31163339 & 100 & 100 & 87 & c.parcial \\
\hline $\mathbf{8 9 2 , 0 3}$ & 71362225 & 62441947 & 31220973 & 100 & 100 & 87 & c.parcial \\
\hline $\mathbf{8 9 3 , 3 1}$ & 71464663 & 62531580 & 31265790 & 100 & 100 & 87 & c.parcial \\
\hline $\mathbf{8 9 9 , 1 0}$ & 71927806 & 62936830 & 31468415 & 100 & 100 & 88 & c.parcial \\
\hline
\end{tabular}

